\title{
A Lower Carboniferous microflora from the Orslev No. 1 borehole, island of Falster, Denmark
}

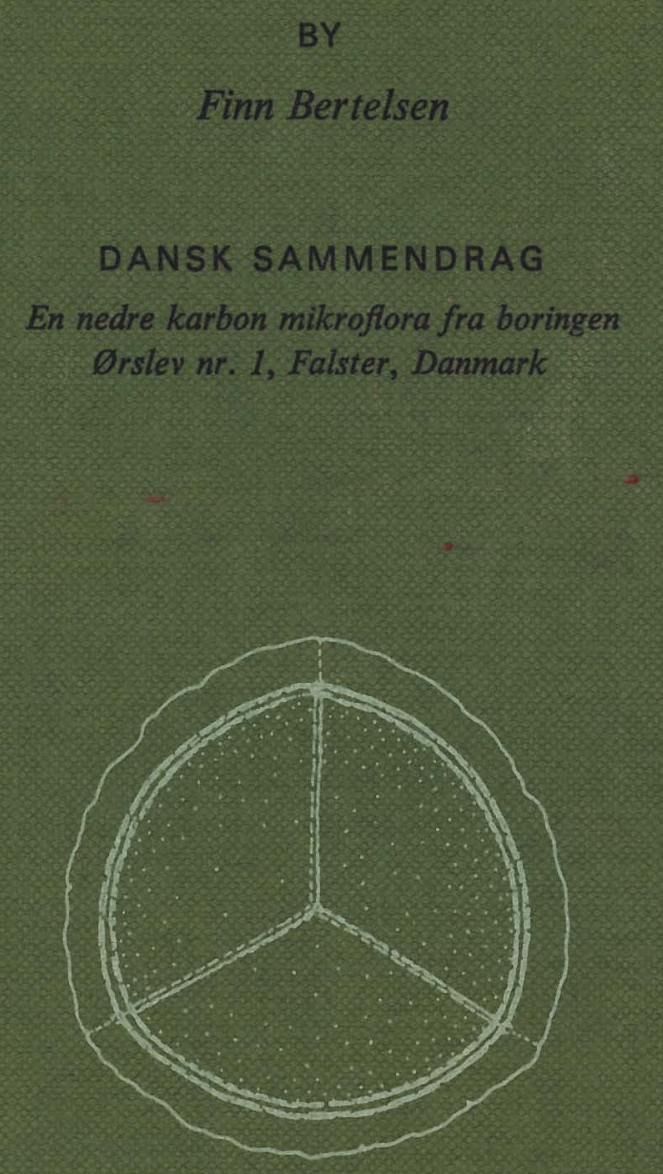


DANMARKS GEOLOGISKE UNDERSØGELSE

II. R ÆKKE. NR. 99

Geological Survey of Denmark. II. Series. No. 99

\title{
A Lower Carboniferous microflora from the Ørslev No. 1 borehole, island of Falster, Denmark
}

\author{
By \\ Finn Bertelsen \\ Dansk sammendrag: \\ En nedre karbon mikroflora fra boringen \\ Ørslev nr. 1, Falster, Danmark
}

I kommission hos

C. A. REITZELS FORLAG

KøBENHAVN 1972 
D.G.U. II. rk. nr. 99

er sat med Monotype Times

og trykt i 1500 eksemplarer

hos Andelsbogtrykkeriet i Odense.

Bogen er trykt på ekstraglittet 605, $125 \mathrm{~g}$

og plancherne på Top-Cote 101, 120 g

fra a/s De forenede Papirfabrikker

ISBN 8742106222

With 24 plates

Date of publication: 1972-09-15 


\section{CONTENTS}

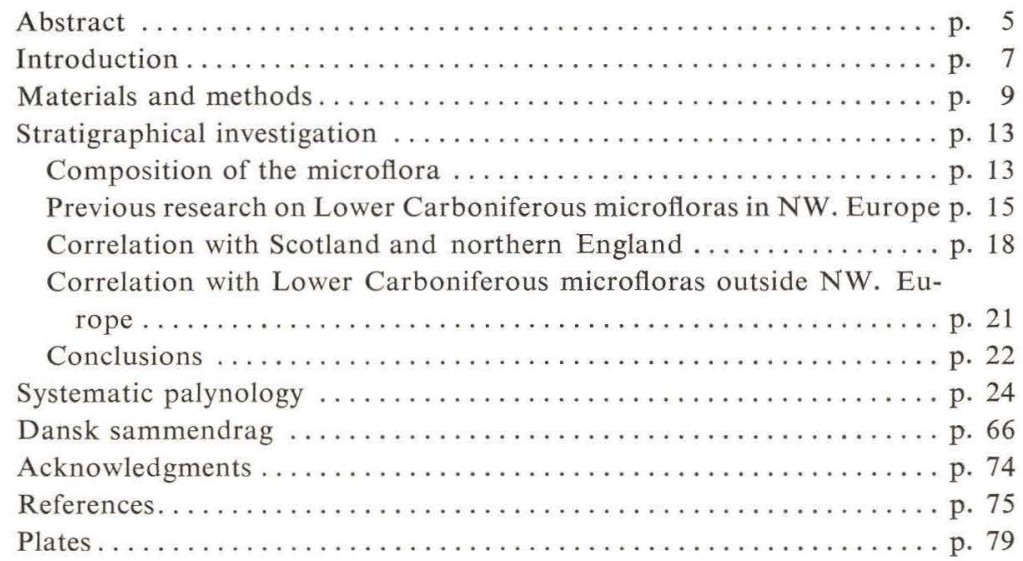




\begin{abstract}
A miospore assemblage comprising 80 species is recorded from Lower Carboniferous strata in the Ørslev No. 1 borehole, island of Falster, Denmark. 45 spore types are referred to known species and 6 are proposed as new. The remaining forms are described with open nomenclature.

The present knowledge of the Lower Carboniferous microfloras and their distribution within NW. Europe is briefly summarized. It is shown, that the Ørslev assemblage has a composition very close to that of the Lycospora pusilla $(\mathrm{Pu})$ Zone assemblages from Scotland and northern England. Outside NW. Europe it shows affinities to spore assemblages described from eastern Canada and the south-west areas of the Soviet Union. The stratigraphical implications of these correlations are discussed. By means of indirect correlations the spore containing beds are referred to the Belgian Upper Tournaisian or Lower Viséan.
\end{abstract}

\title{
PEЗЮME
}

В настоящей работе дается краткое обобщение современных знаний о микрофлоре нижнего карбона и ее распространении в Северо-Западной Европе.

Основное внимание уделено комплексу миоспор, обнаруженному буровой скважиной Ӧрслев № 1 на острове Фальстер (Дания). Комплекс состоит из 80 видов, из которых 45 относятся к известным споровым типам, а 6 являются новыми. Остальные формы описаны в открытой номенклатуре.

Состав ӧрслевского комплекса очень близок к комплексу зоны Lycospora pusilla $(P u)$. Шотландии и Северной Англии. Вне Северо-Западной Европы он имеет сходство со споровыми комплексами Восточной Канады и юго-западных районов Советского Союза. Дается разбор стратиграфической сопричастности этих сопоставлений. Путем косвенных сопоставлений предполагается, что отложения, содержащие данный комплекс миоспор, по возрасту относятся к верхнему турне или нижнему визе Бельгии. 


\section{INTRODUCTION}

In Denmark deposits of Carboniferous age were recorded with certainty for the first time in the Ørslev No. 1 borehole (D.G.U. file No. 238.502). Text-fig. 1 shows the location of the borehole on the island of Falster in the southern part of the country. The boring, made by the Danish Underground Consortium (D.U.C.) reached its final depth, 8440' $(2573 \mathrm{~m}$ ) in January 1968.

Below a series of Upper Permian (Zechstein) evaporites, 750' (229 m) of reddish shales, siltstones and sandstones, tentatively assigned to the Upper Carboniferous or Lower Permian (Rotliegendes) were recorded. These in turn are underlain, between $6740^{\prime}(2051 \mathrm{~m})$ and the base of the bore at $8440^{\prime}(2573 \mathrm{~m})$, by a series of alternating grey and black claystones (shales), marlstones and limestones, generally containing a rich benthonic fauna of brachiopods, corals, crinoids, foraminifera and ostracods.

These latter beds have been described in two recently published papers by Christensen (1971) and Michelsen (1971). Two cores only, from between 6850'-6898' (2088-2103 m, Core No. 1) and 7686'-7746' (2343-2361 m, Core No. 2) (cf. text-fig. 2), were recovered and their lithology and fossil content described by CHRISTENSEN, who previously in 1968 (unpublished report) had shown these beds to be of Lower Carboniferous age. Following a comparison with the Lower Carboniferous section on the Island of Rügen (D.D.R.) and its fauna he suggested $(1971$, p. 21), that the Tournaisian was present in the lowermost part of the Ørslev No. 1 bore, and that the upper part of the section, including Core No. 2 was of Viséan age.

MiCheLSEN, briefly described and subdivided the lithology of the entire proved Carboniferous section. He made a detailed analysis of the benthonic foraminiferal faunas and subdivided the section into four faunizones. $\mathrm{He}$ showed that the faunas were comparable with the foraminiferal faunas known from the Lower Carboniferous type area in Belgium and also with those from Rügen. He correlated the Ørslev section with the Lower Viséan $\left(\mathrm{V}_{1}\right)$ and possibly (the uppermost part) with the lower part of the Middle Viséan $\left(V_{2}\right)$ too.

The results of miospore analysis of samples from different levels of the proved Carboniferous section are described in this paper. In addition, short descriptions of other organic-walled microfossils are given. These include scolecodonts, hystrichosphaeres and algae? of the Tasmanites type. Their presence in the deposits may prove to be a valuable contribution to the interpretation of the depositional environment.

All depths are given in English feet (sample depths not corrected) and meters (corrected depths based on Schlumberger logs) below the Kelly Bushing (KB). 


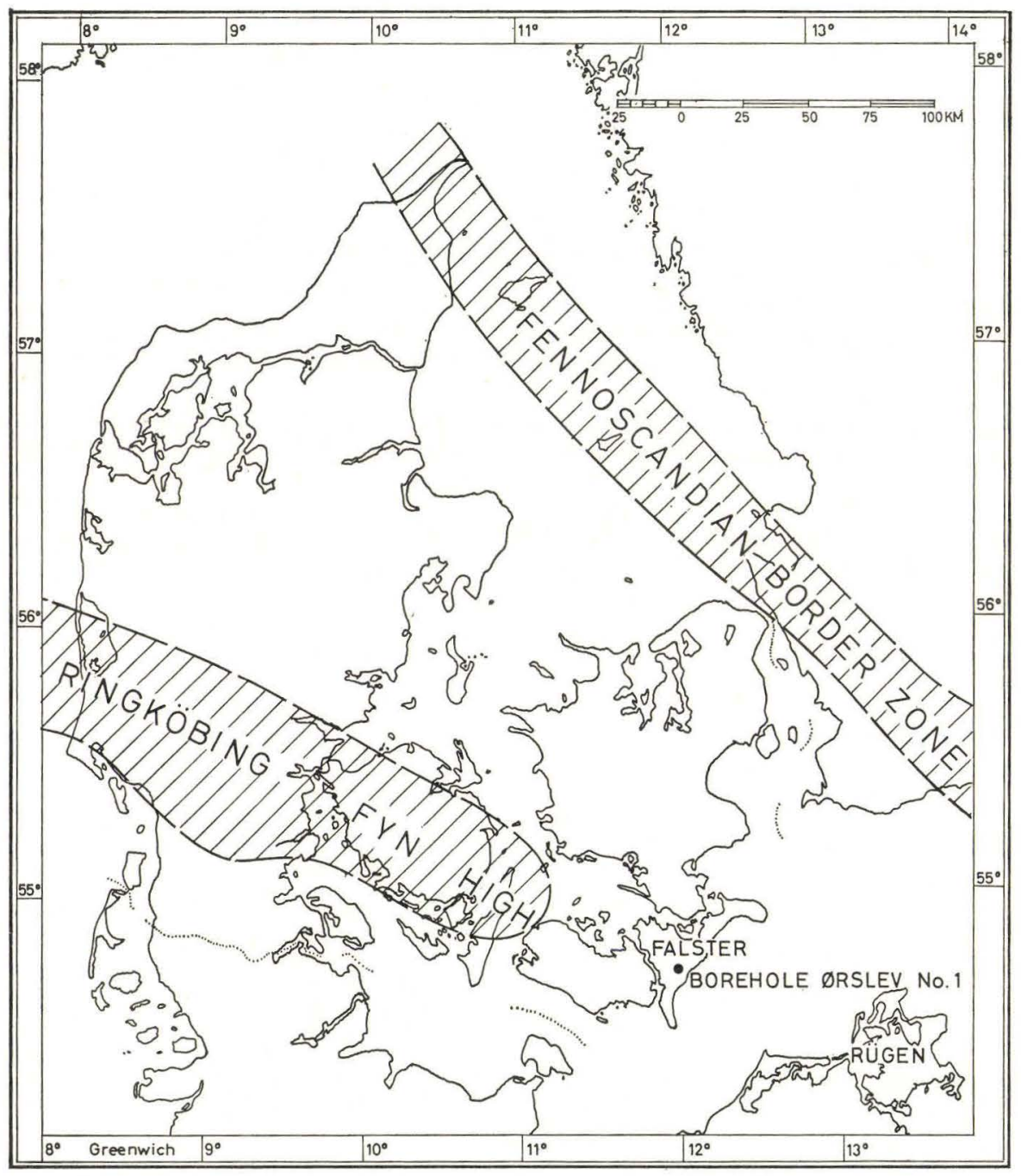

Text-fig. 1: Map showing the location of the Ørslev No. 1 borehole. 


\section{MATERIALS AND METHODS}

The samples.

A general lithological description of the Lower Carboniferous section in the Orslev No. 1 borehole is given by MiCHELSEN (1971). The abbreviated description and the lithological column of text-fig. 2 is taken from this paper. The location of the two cored intervals is shown and also the horizons from which samples have been studied.

The majority of the samples were taken from Core No. $2\left(7686^{\prime}-7746^{\prime}\right)$, at intervals of approximately $3^{\prime}$, throughout the core. Not all the samples taken were prepared, since no marked differences in the spore counts from various levels in the core were observed. The spore assemblages are richest and best preserved in the lowest part of the core.

Spores have been recovered from cuttings of dark grey clay- and marlstones isolated from samples taken in the interval between the two cored sections. The dark claystone of the sample between $7270^{\prime}$ and $7280^{\prime}$ appears to originate in the claystone intercalation $\left(7260-7274^{\prime}, 2213-2217 \mathrm{~m}\right)$ in the limestone beds between 2209 and $2220 \mathrm{~m}$ (cf. text-fig. 2) based on the interpretations of the Schlumberger logs. Two other samples are derived from levels just below the upper limestone beds from which Core No. 1 was taken (cf. text-fig. 2). They are contaminated by cavings of the limestone and the overlying red-coloured beds. Contamination by grey-coloured cavings from the Mesozoic strata may almost certainly be excluded as the last casing is set at 5994' in the top of the red series. As preparations of claystones from these red beds, possibly of Upper Carboniferous or Lower Permian age do not contain spores, it is deduced that the sparse spore assemblages found in the samples, below Core No. 1, represent the youngest part of the Lower Carboniferous in the Ørslev No. 1 borehole.

No spores were obtained from samples taken from Core No. $1\left(6850^{\prime}-6898^{\prime}\right)$. This core is composed of dolomitic limestones.

No samples were studied below Core No. 2 since in this interval it is not possible to locate the cuttings with the necessary precision.

\section{Sample preparation.}

As the sample material is rather uniform in composition, consisting of dark, black-grey shales, claystones and marlstones, the same procedure has been followed for all the samples prepared.

After careful cleaning, about $5 \mathrm{gm}$. of the sample is crushed between two sheets of thick, plastic foil by a hammer. The fraction below $1 \mathrm{~mm}$ is transferred 
to a 200 cc polyethylen beaker and immersed in $20 \% \mathrm{HCl}$ for 24 hours to remove the carbonates. The sample is then washed by centrifuging with distilled water and transferred to a platinum crucible. The silicates are removed by boiling for one hour in $40 \% \mathrm{HF}$. The $\mathrm{HF}$ solution is decanted after centrifuging

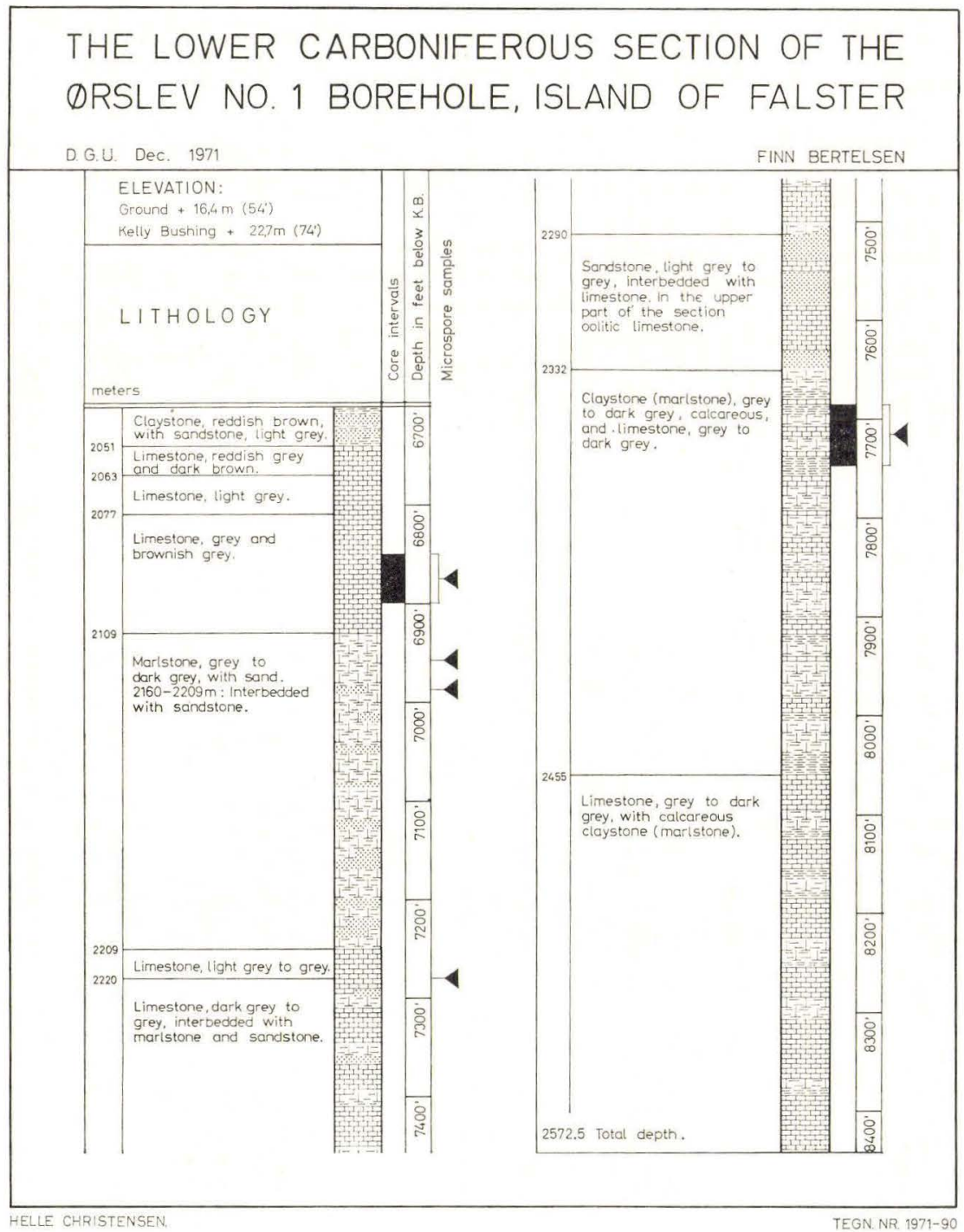

Text-fig. 2.

in a polyethylen centrifuge tube. Heavy-soluble fluorine compounds are dissolved by several treatments with hot, concentrated $\mathrm{HCl}$, involving centrifuging and decanting. After washing with distilled water, the sample is treated for a few minutes with ScHulzE's solution, mainly to remove pyrite. A final wash with 
$1 \% \mathrm{NH}_{4} \mathrm{Cl}$ after washing with distilled water, removes oxidized organic matter.

The residue, now chemically cleaned, is washed on a stainless steel sieve (Dürener Metalltuch, PZ Gewebe, $14 \mu$ mesh) as described by STReEL (1965) and KAISER (1970), transferred to a glass centrifuge tube and washed with distilled water, alcohol and finally benzene. The residue now enriched in spores and free from colloidal particles, is stored in silicone oil (AK 2000). The advantages of this embedding medium are discussed by ANDERSEN (1960). A few samples are stored in glycerine and in some cases glycogel has been used as imbedding medium. At least three strew slides are made of each sample and the cover slips are sealed with paraffin wax. In addition several hundred singlegrain slides have been made

Mounting technique used for scanning electron microscopy.

The spores are isolated from a strew mount of the residue in silicone oil using a "single-hair" brush. Specimens are selected under an optical microscope using transmitted light $(\times 250-\times 400$ magnification). Later they are picked out under a binocular stereomicroscope $(\times 12.5-\times 50$ magnification $)$ and washed in benzene in a watch glass to remove all traces of silicone oil. The low viscosity of glycerine compared with silicone oil makes the former less suitable as a temporary mounting medium.

The cleaned spores are secured to a circular cover-slip either by means of Araldite (a two-component epoxy glue) or "nose-fat". In the first method the adhesive is emulsified in alcohol and a small drop of the emulsion placed on the cover-slip. It is allowed to evaporate so that the residue is spread as a film-like layer over the cover-slip. The amount of emulsion used should be carefully limited in order that the thickness of the Araldite film is not so great that it covers the specimens. If the second and easier method is used it is only necessary to touch the cover-slip lightly with the tip of one's nose, to produce sufficient adhesive and then add a drop of alcohol to form the emulsion.

To attach the cover-slip to the specimen holder and also prevent charging phenomena, conductive silver paint (Dotite paint) is introduced between them. Finally the specimens are coated with either gold or preferably carbon/gold in the high vacuum evaporator.

\section{Storage of preparations and technical data.}

Coordinates of the single-grain and strew slides refer to Leitz Laborlux microscope No. 664225 of the Department of Subsurface Geology, Geological Survey of Denmark. Strew slides are marked with PM, single-grain slides with SM. SH refers to specimen holders used for S.E.M. Transmitted light photography was carried out using a Leitz Orthomat mounted on a Leitz Ortholux microscope, with Ilford FP 4, 35 mm film and a "panchogrün" filter. The scanning micrographs were taken on a Cambridge Stereoscan Mk. Пa 
(Inst. Hist. Geol. Palaeont., University of Copenhagen) and a Jeol JSM-S1 (D.G.U.).

Preparations and holotypes are stored in the type collection of the Department of Subsurface Geology, Geological Survey of Denmark, Copenhagen. Paratypes of the new species proposed in this paper are also stored in the collection of the Department of Geology, University of Sheffield, Great Britain. 


\section{STRATIGRAPHICAL INVESTIGATION}

\section{Composition of the microflora.}

The composition of the microflora studied is diagrammatically shown in textfig. 3. Of the 80 species described or figured, 77 are listed in the diagram. 45 forms are referred to known species, while 6 are proposed as new. The remaining forms are described with open nomenclature. In addition to the 80 species mentioned, some forms referable to the genus Calamospora occur in the samples studied. These forms are not described, but they are included in the totals of the Laevigati in text-fig. 3.

The counts of the core samples are based on 400 to 700 grains from each sample divided on two slides to reduce errors of mixing. The counts of the ditch samples are based on 200 specimens from each sample due to the scantiness of material. Species not recorded in the counted slides, but present in the sample are marked with a point in the diagram.

The uniformity of the assemblages from the core is demonstrated in the diagram. For this reason these assemblages will be treated as one assemblage. The microflora generally is richest in number of soecimens and best preserved in the lower part of the core. It is dominated by two species, Rugospora minuta Neves and Toannides (in press) and Tholisporites decorus BHARADWAJ and Venkatachala, associated with Schopfites claviger Sullivan, Anaplanisporites baccatus (Hoffmeister, Staplin and Malloy) Smith and ButterWORTH and Apiculiretusispora multiseta (LUBER) BUtTERWORTH and SPINNER, the latter three being common. The frequency of the remaining forms is commonly less than $1 \%$. Stratigraphically important is the occurrence of Lycospora pusilla (IвRAHIM) SOMERs (in press) in the core samples.

The assemblage from the ditch sample $7270^{\prime}-80^{\prime}$ (cf. text-fig. 2) is characterized by an abundant occurrence of Lycospora? rugulosa BUTTERWORTH and SPINNER ( $83 \%$ ), in association with S. claviger, A. baccatus, A. multiseta, L. pusilla and $R$. minuta, all being common ( $2-4 \%$ ). The spores of this assemblage are well preserved and the amount of cuticula pieces and fragments in the sample is rather high compared with that of the core samples.

The assemblages of the two uppermost ditch samples, $6980^{\prime}-90^{\prime}$ and $6950^{\prime}-$ $60^{\prime}$, resemble those of the core, but the state of preservation is rather bad. The number of species recorded is lower, but the characteristic species are the same. The fact, that many of the rare species of the core are not recovered is partly due to the limited material available from the ditch samples of which 


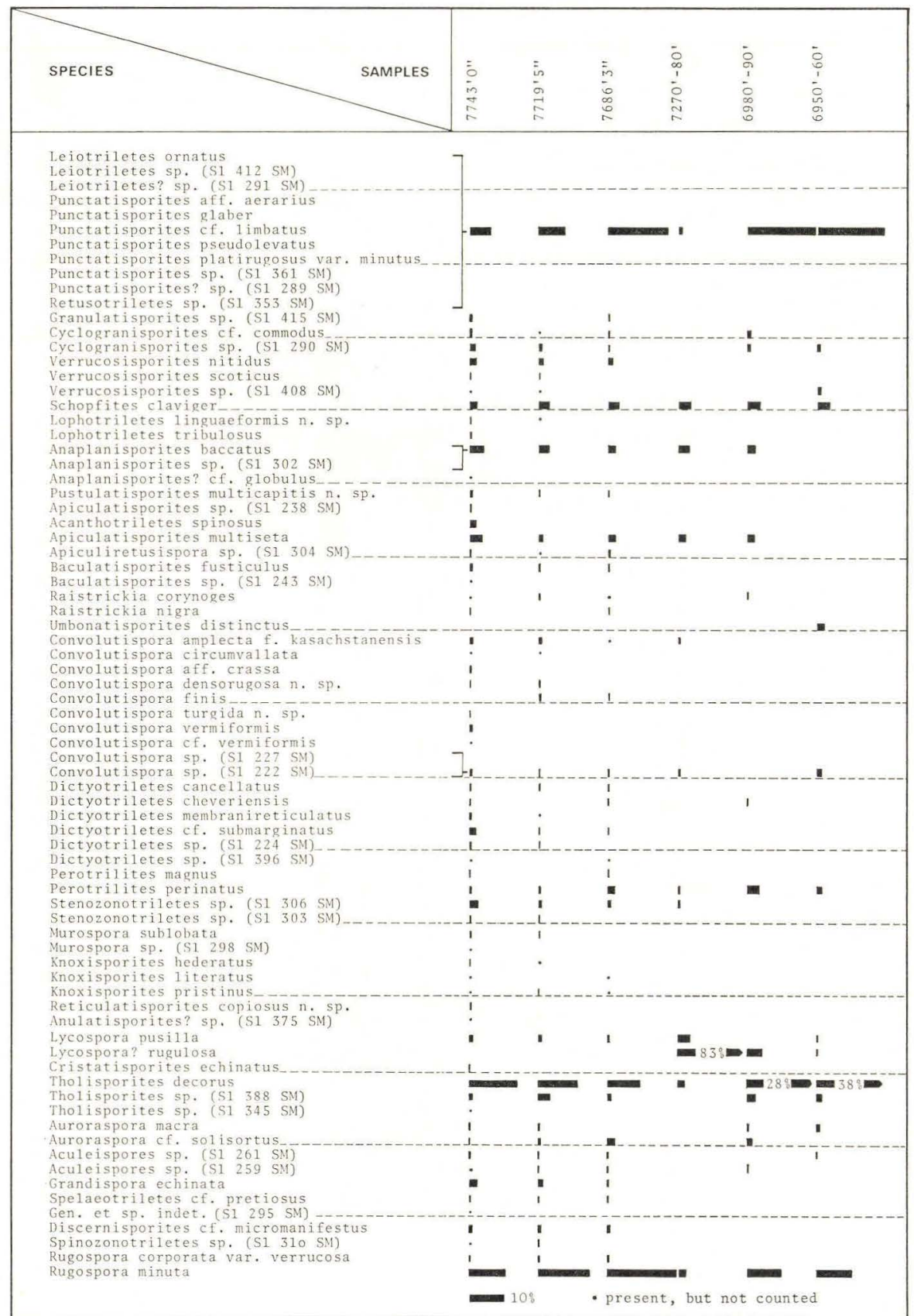

Text-fig. 3: Composition of the microflora. Note: unidentified Calamospora spp. are included in the totals of the Laevigati. 
only a minor part consists of cuttings of dark claystone and shale, the major part being cuttings and cavings of limestone from the superjacent beds. The species, Umbonatisporites distinctus CLAYTON, is the only new form introduced into the microflora in these samples.

In the stratigraphical analysis the microflora of the entire section studied is regarded as one assemblage, although the incoming of $L$. ? rugulosa in the ditch samples marks a change. The main reason has been the close resemblance between the assemblages of the core and the uppermost ditch samples. Also, the diverging sample, $7270^{\prime}-80^{\prime}$, is rich in cuticula fragments, but contains no scolecodonts, and it seems to represent an (par)autochtone, strongly locally influenced microflora, buried in limnic environments. Previous records of L.? rugulosa (Butterworth and Spinner 1967, Marshall and Williams 1970, Neves and Williams 1970) seem to prove that this species is especially abundant in coals.

The other samples contain scolecodonts and (Hystrichophyta), which points at a deposition in the littoral zone, as the scolecodonts are regarded as maxillae of polychaete worms, Errantida, of which modern forms inhabit the coastal oone. The shells of the macrofossils frequently washed? together in thin layers znd the occurrence of few well preserved plants may also be interpreted as indicating shallow water conditions (CHRISTENSEN 1971). Finally the absence of Archaediscidae in the foraminiferal faunas may be due to the facies developed (Michelsen 1971, p. 25). The record of conodonts in the core (CHRISTENSEN 1971 , p. 13) is doubted by the present author. The specimens seem to be fragments of scolecodonts.

The spore assemblages deposited in this type of environment, approximately represent the average flora of a relatively large area of vegetation, since a mixing and an equalizing will take place during the transport and sedimentation. From a stratigraphical point of view such assemblages are more valuable than those of a coal swamp or related facies. For this reason no special attention has been paid to the ditch sample $7270^{\prime}-80^{\prime}$.

The majority of the forms identified with existing species are found to have a stratigraphical range confined to the Lower Carboniferous, while a few extend down into the Upper Devonian or up into the Upper Carboniferous. For a more precise correlation the assemblage is compared with the Lower Carboniferous microfloras described from the neighbouring regions of the North European area of sedimentation.

\section{Previous research on Lower Carboniferous microfloras in NW. Europe.}

Text-fig. 4 shows the areas of localities in north-western Europe from which Lower Carboniferous miospore assemblages have been described.

Miospore assemblages from the Devonian-Carboniferous transition beds have been described in detail from southern Eire by Dolby (1970), from south- 
western England by Suluivan (1964b), Neves and Dolby (1967), Dolby (1970), Dolby and Neves (1970), Utring and Neves (1970), from North-West France by Combaz and Streel (1970) and from the Ardenne-Rhine Basin by Streel (1966, 1968, 1969 and 1970) and PAProth and Streel (1970). The assemblages described are all older than Middle Tournaisian $\left(\mathrm{Tn}_{2}\right)$ (incl.).

In the above mentioned areas, which include the type areas of the Lower Carboniferous chronostratigraphical units Avonian, Tournaisian and Viséan and the type locality of the base of the Carboniferous System (Hönnethal), the spore-containing beds are overlain by thick sequences of limestones. This precludes the erection of a palynological zonation of the younger Lower Carboniferous strata in these areas. Only one microflora of Viséan age has been published from the region encompassed by the above mentioned papers (SulliVAN 1964a).

It follows from this that chronostratigraphical datings of younger Lower Carboniferous microfloras from other areas, especially those derived from nonmarine deposits, will only be the results of one or more indirect correlations, the value of which in many cases may be doubted.

Thick Lower Carboniferous sequences in a non-Carboniferous Limestone facies are present in the Northumbrian and Scottish Provinces of Great Britain (cf. GeORGe 1969). Brackish, limnic, deltaic and lacustrine deposits are the main components of these provinces. Marine horizons are scarce, except in the uppermost beds of both Provinces and in the basal part of sequence in the south-western part of the Northumbrian Province. In these areas the establishment of a coral-brachiopod zonation has proved difficult. On the other hand the region offers the possibility of a study of the development and change of miospore assemblages throughout a large proportion of the Lower Carboniferous.

Miospore assemblages have been described from several localities in the Midland Valley of Scotland (Love 1960, Sullivan and Marshall 1966, Sullivan 1968, Neville 1968, Clayton 1971 and Neves and IoanNides in press), the latter from the Spilmersford borehole, East Lothian, being the most complete profile so far documented. Descriptions of microfloras from the Northumbrian Province are given by BUTTERWORTH and SPINNER (1967), SMith and Butterworth (1967), Neves and Williams (1970) and Marshall and Williams (1970). The microfloras from this province are less well known than those of the Scottish Province.

Miospores from the Central Province of Great Britain have been described by HibBert and LACEy (1969), Llewellyn, BACKHOUSE and Hoskin (1969), Mortimer, Chaloner and Llewellyn (1970) and Johnson and Marshall (1971). The assemblage described by HIBBERT and LACEY from North Wales is of Viséan age $\left(S_{2}\right.$ or $\left.D_{1}\right)$, whereas all the other assemblages are considered to be of Tournaisian age.

Apart from the records from the Ardenne-Rhine Basin there are few palyno- 


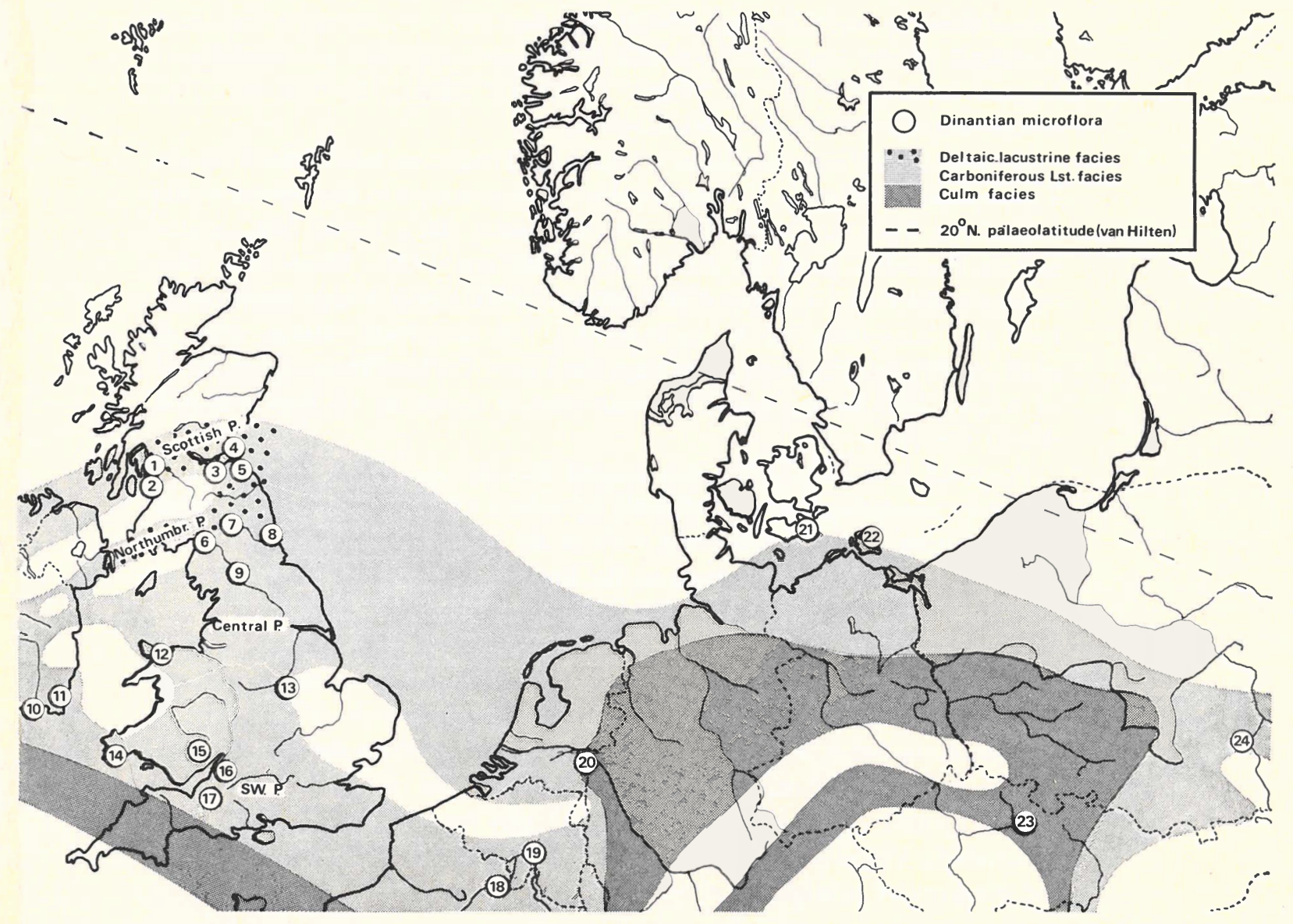

Text-fig. 4: Map showing the areas of localities in North-West Europe, from which Dinantian miospore assemblages have been recorded. The lithofacies of the Lower Viséan is shown as background (after GeORGe 1969 and PAPROTH 1969). The approximate course of the $20^{\circ} \mathrm{N}$. palaeolatitude is drawn after a map in Sullivan (1967).

1) Sullivan and Marshall 1966, 2) Sullivan 1968, 3) Love 1960, Neves and Ioannides in press, 4) Neville 1968, 5) Clayton 1971, 6) Marshall and Williams 1970, 7) ButterWOrth and Spinner 1967, Neves and Williams 1970, 8) SMith and Butterworth 1967, 9) Johnson and Marshall 1971, 10), 11), 14) Dolby 1970, 12) Hibbert and LaCey 1969, 13) Llewellyn, Backhouse and Hoskin 1969, Mortimer, Chaloner and Llewellyn 1970, 15) Sullivan 1964a, 1964b, 16) Utting and Neves 1970, 17) Dolby and Neves 1970, Neves and Dolby 1967, 18-20) Streel 1966-1970, Paproth and Streel 1970, 21) Ørsiev, 22) Rügen, 23) Kalibova 1971, 24) JaChowicz 1967. 
logical descriptions of Lower Carboniferous deposits from the north European mainland. Doubinger and RAuscher (1966) have described a microflora of Upper Viséan age from "Les Vosges" in eastern France. The beds were previously dated on the basis of brachiopods.

Kalibova (1971) has described a Lower Carboniferous microflora from the Tb-1 borehole, Bohemia, Czechoslovakia. A comprehensive description of the microfloras from the Zaręby Beds, Swietokrzyskie (Holy Cross) Mts., southeastern Poland is given by JACHOWICZ (1967 and 1970). These beds were originally dated as Tournaisian by ZAKowA (1962). Upper Viséan assemblages have also been described by JACHOWICZ (1970) a. o. from various areas of southern Poland. The microfloras from the Lower Carboniferous of the island of Rügen, D.D.R., are presently being studied according to KNÜPFER and WEYER (1967).

From the above discussion it is evident that the equivalents of the Ørslev miospore assemblage, dated indirectly by means of foraminifera as being of Lower Viséan age are probably present in the Scottish Province. This is the only area in North-West Europe so far known, where the composition and development of the microflora can be followed continuously through the major part of the Lower Carboniferous. A direct correlation with Belgium is precluded, as it is only possible to follow the development of the microflora through the lowest part of the Lower Carboniferous because of the presence of a limestone facies in the overlying beds. Assemblages from the $\mathrm{Tn}_{2}$ substage are the youngest hitherto recorded in Belgium. In the Swiety Krzyz area of Poland a break in the sequences of assemblages seems to occur close to the Tournaisian/Viséan boundary, and therefore this area is also precluded from the comparative stratigraphical analysis.

\section{Correlation with Scotland and northen England.}

The Ørslev assemblage is directly comparable to those of the Lycospora pusilla (Pu) Zone described by Neves and IOANNides (in press) from the Spilmersford borehole, East Lothian, Scotland. The zone is differentiated from the underlying Schopfites claviger-Auroraspora macra (CM) Zone by the first appearence of $L$. pusilla (IвRAHIm) Somers (in press), a species present, but only in small numbers in the Ørslev assemblage. The zone is characterized by the presence of L. pusilla in association with several species also recorded in the Ørslev assemblage: Verrucosisporites nitidus (NAUmova) Playford, Schopfites claviger Sullivan, Baculatisporites fusticulus Sullivan, Raistrickia corynoges Sullivan, Knoxisporites literatus (Waltz) Playford and Auroraspora macra Sullivan.

Tholisporites decorus BharadwaJ and Venkatachala, Dictyotriletes cancellatus (Waltz) Potonié and Kremp and Anaplanisporites baccatus (Hoffmeister, Staplin and Malloy) Smith and Butterworth of which the firstand last-mentioned species are common in the Ørslev assemblage are also 
recorded in this zone and also from the zones immediately above and below in the Spilmersford borehole.

Vallatisporites ciliaris (LUBER) SULLIVAN and Knoxisporites stephanophorus Love are species initiating the transition to the overlying Perotrilites tessellatusSchulzospora campyloptera (TC) Zone (Neves, GueInN, Clayton, IOANNides and Neville in press). Neither of these or any other forms occuring for the first time in the TC Zone are found in the samples studied. The appearence of Lycospora? rugulosa BUtTerworth and SPINNER in the ditch samples from the upper part of the section studied indicates that the upper assemblage may be correlated with the middle part of the $\mathrm{Pu}$ Zone, since the oldest of the published records of this species seems to be that of BUTTERWORTH and SPINNER (1967) from the Cambeck Beds of North-West England, where it occurs associated with a species of the uppermost part of the Pu Zone ( $V$. ciliaris). The Cambeck Beds ( $C_{2}$ age) is correlated with the Lower Viséan (DAY 1970).

As the results of the work of NEVES and IOANNIDES on the Spilmersford borehole are not yet published it is difficult to compare them in detail with the Ørslev assemblage. Clayton (1971), from the Cockburnspath area of SouthEast Scotland published a description of an assemblage which would appear to be slightly older than the assemblage of Core No. 2. Apart from the absence of Lycospora spp., which according to CLAYTON $(1971$, p. 597) occur only $30 \mathrm{ft}$ above the youngest sample described by him in the Birnieknowes borehole, the assemblages are very similar. Species recorded by CLAYTON are shown in text-fig. 5. Those marked with an asterisk also occur in the Ørslev assemblage.

The assemblages described by BUTTERWORTH and SPINNER (1967) (cf. textfig. 5) from the Cambeck Beds $\left(\mathrm{C}_{2}\right)$ and the older Bewcastle Beds $\left(\mathrm{C}_{1}\right.$, cf. DAY 1970) of North-West England are correlated with the upper part of the Pu Zone based on the occurrence of $V$. ciliaris (Neves, Gueinn, Clayton, IoAnNides and NeVILLE in press). These assemblages are restricted in the number of species they contain and are best compared with the assemblage of the ditch sample $7270^{\prime}-7280^{\prime}$. They do not have the same pronounced similarity to the assemblage of Core No. 2 as do those from Cockburnspath. However they are the only assemblages so far published from the $\mathrm{Pu}$ Zone in the two northern provinces.

The $\mathrm{Pu}$ Zone is considered to be more or less equivalent to the coralbrachiopod zone $C_{1}$ (Neves, Gueinn, Clayton, Ioannides and Neville in press). New studies of the foraminiferal faunas in the South-West Province of Great Britain suggested that the Caninia Oolite should be correlated with the Lower Viséan of Belgium ( $V_{1 a}$ or probably $V_{1 b}$ ) (cf. ConIL and George 1971). The upper part of the Lower Caninia Zone $\left(\mathrm{C}_{1}\right)$ including the Caninia Oolite is therefore referable to the Lower Viséan of Belgium and not as previously to the Tournaisian. Deposits characterized by Pu Zone assemblages may therefore be indirectly referred to the Upper Tournaisian-Lower Viséan of Belgium. 


\section{COCKBURNSPATH ASSEMBLAGE \\ (Clayton 1971)}

* Anaplanisporites baccatus Auroraspora balteola

* Auroraspora macra

*? Auroraspora solisortus

* Baculatisporites fusticulus

* Convolutispora circumvallata C. flexuosa f. major

*? C. cf. mellita

* Corbulispora cancellata Crassispora trychera Cristatisporites bellus

*? Cyclogranisporites commodus Discernisporites crenelatus

*? D. micromanifestus Knoxisporites cinctus

* K. literatus

$K$. literatus var. triangularis

Lophozonotriletes bellus L. sp. $A$.

Microreticulatisporites hortonensis

* Perotrilites magnus

* Perotrilites perinatus Proprisporites undosus Pulvinispora scolecophora

* Raistrickia corynoges Retusotriletes incohatus

*? Rugospora cf. corporata

* Schopfites claviger S. cf. claviger

* Spelaeotriletes cf. pretiosus Spinozonotriletes uncatus

* Tholisporites cf. decorus

* Umbonatisporites distinctus

* Verrucosisporites nitidus

* V. scoticus

V. variotuberculatus

\section{CAMBECK BEDS} ASSEMBLAGE

(BUTTERWORTH and SPINNER 1967)
Retusotriletes incohatus

* Cyclogranisporites commodus

* Anaplanisporites baccatus

* Apiculiretusispora multiseta Convolutispora planimuricata Dictyotriletes pseudopalliatus

*? Endosporites micromanifestus Velosporites echinatus Lycospora noctuina

* Lycospora rugulosa Lycospora tenebricosa Vallatisporites ciliaris

\section{BEWCASTLE BEDS} ASSEMBLAGE

(Butterworth and SPINNER 1967)

Retusotriletes incohatus

* Apiculiretusispora multiseta

Raistrickia ponderosa

Convolutispora cf. finis

Knoxisporites literatus

*? Endosporites micromanifestus

Lycospora noctuina

Vallatisporites ciliaris

* Perotrilites perinatus

Note: Laevigati are excluded from the species lists.

$*=$ species recorded in the Ørslev assemblage.

The Cockburnspath assemblage represent 13 samples, the Bewcastle Beds assemblage and the Cambeck Beds assemblage only 1 sample each.

Text-fig. 5: Miospore assemblages from Scotland and North-West England comparable with the Ørslev assemblage. 
Correlation with Lower Carboniferous microfloras outside $N W$. Europe.

U.S.S.R.

The comparison with the Lower Carboniferous miospore assemblages described from various parts of the Soviet Union is for linguistic reasons only superficial. Only a small part of the Russian literature has been available and the value of the comparisons made below is therefore debatable.

A comparison has been made with the spore assemblages described by Kedo $(1963,1966)$ from the Pripyat depression, an area north-west of Kiev, White Russia. The Ørslev assemblage is perhaps, best compared with those of the Bobrikov 2 "complex".

This is characterized by the first occurrence of L. pusilla. Apiculiretusispora multiseta (LUBER) BUtTERWORTH and SPINNER and Acanthotriletes dominans Kedo $=$ ? Acanthotriletes spinosus (NAumova) Ischenko, both common in the Ørslev assemblage, are characteristic members of the Bobrikov 1 and Bobrikov 2 assemblages (cf. KEDo 1966, pl. XII).

Although the Pripyat depression may be presumed to have been located at the same palaeolatitude as Ørslev and the Midland Valley of Scotland, the assemblages from it do not bear much resemblance to those from the latter two areas. This is in contrast to the similarity between the Scottish and Danish assemblages. The Bobrikov horizon is referred by PAPROTH (1969, p. 289, table VII) to the Viséan, $\mathrm{V}_{1 \mathrm{~b}}$ of Belgium and to $\mathrm{C}_{1}^{\mathrm{V}} \mathrm{d}$ of the Donetz Basin.

Comparisons with the Donetz Basin are based on the range charts of Ischenko (1956). Only a few species recorded in the Donetz assemblages are present in that from Ørslev.

Convolutispora amplecta f. kasachstanensis (LUBER) JACHOWICZ, Dictyotriletes cancellatus, Knoxisporites hederatus (Ischenko) Playford and Knoxisporites literatus have a vertical range comprising $\mathrm{C}_{1}^{\mathrm{t}}$ and $\mathrm{C}_{1}^{\mathrm{v}} \mathrm{a}-\mathrm{e}$. Punctatisporites platirugosus (Waltz) Sullivan var. minutus Waltz, Punctatisporites glaber (Naumova) Playford, A. spinosus and L. pusilla do not occur in strata older than $\mathrm{C}_{1}^{\mathrm{v}}$ a. Leiotriletes ornatus IsCHENKo is restricted to deposits younger than $\mathrm{C}_{1}^{\mathrm{v}} \mathrm{f}$. Lophotriletes aff. grumosus NAUmova $=$ ? Verrucosisporites nitidus (NAUmova) Playford is not recorded in deposits younger than $C_{1}^{t} d$.

On the basis of these ranges the Ørslev assemblage can be correlated with the $\mathrm{C}_{1}^{\mathrm{v}} \mathrm{a}-\mathrm{e}$ interval of the Donetz Basin. This is approximately equal to the Lower Viséan of Belgium, as the overlying subzone $C_{1}^{v} f_{1}$ can be correlated with some certainty with $V_{2 b}$ in Belgium and $C_{1}^{t} c$ can be correlated with $T_{2 b-2 c}$ (Aisenverg, Brazhnikova and Vdovenko 1971). The interval between these two horizons is difficult to correlate with Belgium since the two areas had different facies developed at this time.

Several of the species used in the above correlation have proved to have a greater vertical range in the Donetz Basin than quoted above (IsCHENKo 1958). This does not alter the general correlation. 


\section{Canada.}

A spore assemblage figured by BARss (1967, pl. 5-6) has many points of resemblance with the Ørslev assemblage. Of note are the numerous illustrations of cavate or "perinate" spores. Some of the forms illustrated as Secarisporites? spp. are probably identical with Rugospora minuta Neves and IOANNIDES (in press), the dominating species of the Ørslev assemblage.

The assemblage was obtained from a horizon within the Windsor Group of eastern Canada and stated by BARss to be of Viséan age. The precise level within the group is unknown. The general correlation of the Windsor Group to the European standard zonation is still not clear. PLAYFORD (1963b) mentions that the lower part of the Windsor Group on the basis of a marine fauna is taken to be of Early Viséan age. Neves and Belt (1970) state that the Windsor Group is of Middle to Late Viséan age. The assemblage figured by BARss is different from that recorded from the upper part of the Windsor Group by NEVES and BeLT, which contains a microflora comparable with that of Late Viséan age in Scotland. The age of the assemblage figured by BARSS is probably of Early or Middle Viséan age.

Spore assemblages from the underlying Horton Group have been described by Hacquebard (1957), Playford (1963b) and Varma (1969). The microflora of the uppermost formation of the Horton Group, the Cheverie Formation, is comparable to that of the Schopfites claviger-Auroraspora macra (CM) Zone in Scotland and several species of the Ørslev assemblage occur in these strata. The older assemblages of the Undifferentiated Horton Group may be compared with those described from the Lower Limestone Shales of Burrington Combe (Dolby and Neves 1970) and Forest of Dean (SulLivan 1964b), having several diagnostic species in common.

The Lower Carboniferous miospore assemblages from north-western Canada described by Hacquebard and BArss (1957) and PlAyFord and Barss (1963) were assigned by Sullivan (1965) to his Monilospora suite, representative of a northern floral province, along with those described from Spitsbergen by Hughes and Playford (1961), Bharadwaj and Venkatachala (1961) and PlAYFORD (1962-1963a). Comparison with these assemblages is not made here.

\section{Conclusions.}

The miospore assemblage from the Ørslev borehole is comparable to those described from eastern Canada (Lower part of the Windsor Group and the underlying Cheverie Formation of the Horton Group), Scotland (Pu Zone of the Calciferous Sandstone Measures), northern England (Bewcastle Beds and Cambeck Beds) and the Soviet Union (Bobrikov 2 horizon of the Pripyat depression, White Russia and the $\mathrm{C}_{1}^{\mathrm{v}}$ stage of the Donetz Basin).

The greatest similarity exists between those from Scotland, northern England, eastern Canada and Ørslev. This is interpreted as a consequence of the former 
closer position of these areas. It seems to prove that the spore producing plant community growing along the southern edge of the former "Old Red Continent" was uniform over long distances. Palaeomagnetic measurements and the facies developed (reefs etc.) show the climate to have been tropical. Semi-arid environments seem to have been necessary for the formation of the Cementstone facies in Canada and Scotland (Belt et al. 1967, Neves and Belt 1970) and may also have existed within the Danish area.

The assemblages which are considered comparable to that of the Ørslev borehole have all been indirectly assigned to the Upper Tournaisian or Lower Viséan as defined in Belgium. Thus the Ørslev assemblage is indirectly correlated with the Belgium type area and this supports the conclusions of MiCHELSEN (1971), who referred the Lower Carboniferous section of the borehole to the Lower and Middle? Viséan and Christensen (1971), who referred the section to the Tournaisian? and Viséan. 


\section{SYSTEMATIC PALYNOLOGY}

Notes to the descriptions. The systematic classification of the miospores is traditionally based on the artificial morphographic taxonomic system of PотоNIÉ (1956-1970). The descriptive terminology recommended by the C.I.M.P.(GreBE 1971) has been followed as far as possible.

The Hystrichophyta have been classified in accordance with the system established by MÄDLER (1963).

\section{MIOSPORES}

Anteturma Sporites H. Potoní́ 1893

Turma Triletes REINSCH 1881

Subturma Azonotriletes WaLtz 1935

Infraturma Laevigati (BENNIE and KIDSTON) PotoniÉ 1956

Genus Leiotriletes (NAumova) Potonié and Kremp 1954

Leiotriletes ornatus ISCHENKO

Pl. I, figs. 1-2.

1956 Leiotriletes ornatus Ischenko, p. 22; pl. 2, figs. 18-21.

1960 Spore type 1 of Love, p. 122; pl. 2, fig. 9 and text-fig. 12.

1962 Leiotriletes ornatus IshCHENKo - Playford, p. 575; pl. 78, figs. 7, 8.

1966 Leiotriletes ornatus Ish. - DoubINGER and RAuSCher, p. 364; pl. 1, fig. 4, 5.

1967 Leiotriletes ornatus IsCHENKO - JACHOWICZ, p. 17; pl. 3, fig. 9.

1967 Leiotriletes ornatus IsChenko - Felix and Burbridge, p. 354; pl. 53, fig. 3.

1970 Leiotriletes ornatus IsHCHENKo - KAISER, p. 83; pl. 16, fig. 7.

Description. Miospores trilete, acavate. Diameter $38-50 \mu$ (5 specimens). Amb convexly triangular with broadly rounded apices. Suturae labrate, straight, distinct, almost equal to spore radius. Labra low, smooth, distinct, individually $4 \mu$ in width. Borders of labra straight. Exine laevigate, $2-2.5 \mu$ thick, rarely folded.

Stratigraphical range. Up. Devonian to L. Namurian.

Geographical distribution.

Europe: Scotland (Love 1960), England (Sullivan 1964b, Dolby and Neves 1970, Utting and Neves 1970), France (Doubinger and Rauscher 1966), Belgium-Germany (cf. Streel 1970), Poland (JACHOwiCz 1967).

U.S.S.R.: IsCHENKo (1956, 1958).

Arctic region: Spitsbergen (PLAYFORD 1962), Bear Island (KAISER 1970).

North America: U.S.A. (Felix and Burbridge 1967). 


\section{Leiotriletes sp. (Sl 412 SM) \\ Pl. I, fig. 9.}

Description. Miospores trilete, acavate. Diameter $75 \mu$ (only one specimen was satisfactorily preserved). Amb convexly triangular. Apices rounded. Suturae labrate, straight, distinct, equal to spore radius. Labra $3-4 \mu$ high, narrow. Exine laevigate, $1 \mu$ thick, "fragile".

Remarks. This spore type has been recorded in several samples, but the specimens are more or less destroyed due to the "fragile" nature of the exine.

\section{Leiotriletes? sp. (SI 291 SM)}

Pl. I, fig. 3.

Description. Miospores trilete, acavate?. Diameter 34-61 $\mu$, mean $46 \mu$ (10 specimens). Amb convexly triangular. Apices rounded. Suturae labrate, straight to sinuous, almost equal to spore radius. Labra raised, 3-4 $\mu$ high, narrow. Exine finely infrapunctate, $1 \mu$ thick.

Remarks. Leiotriletes tumidus Butterworth and Williams 1958, p. 359, has some resemblance to the above described spore type. L. tumidus has a laevigate structureless exine and is acavate. L.? sp. (S1 291 SM) is possibly camerate. The infrapunctation of the exine prevents its observation, but colour differences may indicate the presence of a separated intexine.

Genus Calamospora Schopf, Wilson and Bentall 1944

\section{Calamospora spp.}

Remarks. Calamospora spp. occur frequently in the preparations. As they commonly are heavily folded and non-measurable a description is omitted.

Genus Punctatisporites (Ibrahim) Potonié and Kremp 1954

Punctatisporites aff. aerarius BUTTERWORTH and WILLIAMS 1958

Pl. II, fig. 5.

Description. Miospores trilete, acavate. Diameter 55-76 $\mu$ (5 specimens). Amb circular. Suturae labrate, straight, distinct, $0.3-0.5$ radius of spore. Labra $2-3 \mu$ high, membraneous. Exine laevigate, $2.5-4 \mu$ thick, only rarely folded.

Remarks. The above described specimens have shorter suturae than stated for the species by BUTTERWORTH and Williams (1958, p. 360; pl. 1, figs. 10-11.): "rays slightly longer than half radius". Otherwise they are identical. The spores described by KAISER as P. aerarius (1970, p. 85; pl. 16, fig. 12) have suturae being $2 / 3$ radius of spore. They may perhaps better be identified with $P$. planus HaCquebard 1957. P. aerarius has previously been recorded from the Viséan 
and Namurian of Scotland (Butterworth and Williams 1958, Love 1960, Sullivan and Marshall 1966, Smith and Butterworth 1967) and from the North Western Territories of Canada (BARss 1967).

\author{
Punctatisporites glaber (NAUMOVA) PlAYFord 1962 \\ Pl. I, figs. 8, 10.
}

1938 Azonotriletes glaber (Naumova) Waltz in Luber and Waltz, p. 11; pl. 1, fig. 2 and pl. A, fig. 3.

1956 Leiotriletes glaber NAUMOVA - IsChenko, p. 18; pl. 1, figs. 7, 8.

1958 Leiotriletes glaber NAUMOVA - Ischenko, p. 34; pl. 1, fig. 4.

1962 Punctatisporites glaber (Naumova) Playford, p. 576; pl. 78, figs. 15, 16.

Description. Miospores trilete, acavate. Diameter $42-75 \mu$, mean $60 \mu$ (21 specimens). Amb circular to strongly convexly triangular with broadly rounded apices. Suturae simple, straight, distinct, $0.5-0.8$ radius of spore. Exine laevigate to very finely infragranular, $1.5-2.5 \mu$ thick (commonly $2 \mu$ ), often with a few compression folds.

Remarks. This species is not clearly distinguished from $P$. nitidus Hoffmeister, Staplin and Malloy 1955 and allied forms. A list of species possibly belonging to $P$. glaber is given by PLAYFORD (1962).

Stratigraphical range. Up. Devonian to L. Namurian.

Geographical distribution. P. glaber and allied forms have been recorded from several localities in Europe, North America and U.S.S.R.

\title{
Punctatisporites ef. limbatus HACQUeBARD 1957
}

Pl. II, fig. 2.

Description. Miospores trilete, acavate. Diameter $62-103 \mu$, mean $77 \mu$ (10 specimens). Amb circular to slightly oval. Suturae simple to labrate, straight, distinct, $0.5-0.8$ radius of spore. Labra, when present, $1-3 \mu$ high, membraneous, raised. Exine laevigate to finely infrapunctate, $1-1.5 \mu$ thick. A pseudolimbus commonly $5 \mu$ in width, may be developed by a collapse of the thin exine along the equator. Within this pseudolimbus a row of pyrite crystals is often seen (see pl. II, fig. 2), which shows that the two layers of the exine have been in close contact but not united. Concentric folding is often observed along the inner borderline of a "limbus".

Remarks. P.? limbatus HaCquebard (1957, p. 308; pl. 1, figs. 9-11) is larger (111-206 $\mu$ ) than the spores described above. In other respects they are identical. The spores described by Playford (1963b) as P. limbatus have a thick exine (4-8 $\mu$ ) and broad labra. They are not regarded to be identical with $P$. ? limbatus Hacquebard. P.? limbatus is described from the Horton Group (Mississippian) of Nova Scotia, Canada. 
Punctatisporites pseudolevatus Hoffmeister, Staplin and Malloy 1955 Pl. II, fig. 1.

1955 Punctatisporites pseudolevatus Hoffmeister, Staplin and Malloy, p. 394; pl. 36, fig. 5 .

Description. Miospores trilete, acavate. Diameter $56-77 \mu$ (5 specimens). Amb circular to strongly convexly triangular with broadly rounded apices. Suturae simple to labrate, straight to slightly sinuous, $0.6-0.8$ radius of spore. Labra, when present, 1-3 $\mu$ high, raised, membraneous. Exine distinctly infragranular with fine grana spread over the surface, $1.5-2.5 \mu$ thick. Arcuate folding common.

Remarks. The optical section of the exine of this species is difficult to study due to the granular structure of the exine. It differs from P. glaber (NAumova) only by differences in the structure of the exine (cf. P. glaber p. 26). The size variation of the type specimens is $50-74 \mu$.

Stratigraphical range. Viséan to Namurian.

Geographical distribution.

Europe: Scotland (Butterworth and Williams 1958, Love 1960).

North America: U.S.A. (Hoffmeister, Staplin and Malloy 1955).

\section{Punctatisporites platirugosus (WALtZ) Sullivan 1964 var. minutus WALTZ} Pl. I, figs. 6-7.

1956 Leiotriletes platirugosus (WALtz) var. minutus WALtz - Ischenko, p. 16; pl. 1, figs. 5-6.

1964a Punctatisporites platirugosus (Waltz) Sullivan, p. 358; pl. 57, figs. 7-9.

Description. Miospores trilete, acavate. Diameter $30-47 \mu$, mean $42 \mu$ (12 specimens). Amb circular. Suturae simple or labrate, straight, distinct, 0.5-0.8 radius of spore. Labra, when present, $1-2 \mu$ high, raised, membraneous. Exine laevigate to punctate (corrosion), $1-1.5 \mu$ thick, often folded.

Remarks. IscHENKO records a size range of this variety of $30-50 \mu$. The size variation of the type material is according to IsCHENKo $32-47 \mu$. The size variation of the above described spores agrees closely with those ranges. The size ranges given by SulLIVAN is $30-70 \mu$. This range comprises the two varieties minutus and minor. Many species, e.g. P. obliquus Kosanke 1950, P. minutus Kosanke and $P$. debilis Hacquebard 1957, are comparable to $P$. platirugosus var. minutus. and may prove to be identical with the latter.

Stratigraphical range. Tournaisian? to Namurian.

Geographical distribution.

Europe: England (SulLivan 1964a).

U.S.S.R.: ISCHENKO (1956), KEDO (1966). 


\section{Punctatisporites sp. (SI 361 SM) \\ Pl. II, figs. 3-4.}

Description. Miospores trilete, acavate. Diameter $47-78 \mu$ (7 specimens). Amb circular to broadly convexly triangular with rounded apices. Suturae simple, straight, distinct, $0.6-0.8$ radius of spore. Exine laevigate (may be pitted by corrosion), 3-4 $\mu$ thick, rarely folded, fractures common.

Remarks. P. solidus HACQUEBARD 1957 differs from P. sp. (S1 361 SM) in being distinctly labrate. Leiotriletes microgranulatus PLAYFORD 1962 is more triangular than $P$. sp. (Sl $361 \mathrm{SM}$ ) and the structure of the exine is granular in this species.

\section{Punctatisporites? sp. (SI 289 SM) \\ Pl. I, figs. 4-5.}

Description. Miospores trilete, acavate. Diameter $62 \mu$ (only one specimen is recorded). Amb circular. Suturae labrate, straight, distinct, 22-28 $\mu$. Labra very low and flat, individually $2-4 \mu$ in width, having lobate borders. Exine laevigate, of uneven thickness $(0.5-3 \mu)$. Thickenings inwardly and outwardly directed. The thickened areas more or less rounded, appr. 5-10 $\mu$ in diameter, slightly darker than the thinner areas.

Remarks. P. sinuatus (ARtüz) Neves 1961 (cf. also SMith and Butterworth, 1967, pl. 2, fig. 2) and Convolutispora planimuricata BUTTERWORTH and SPINNER, 1967 , p. 7, have a type of sculpture comparable to the above described spore. The characteristic development of the labra of $P$.? sp. (S1 $289 \mathrm{SM}$ ) is not seen in these two species, both having simple suturae. This spore type is tentatively included in the genus Punctatisporites, since the sculpture is extremely low and badly defined.

\section{Genus Retusotriletes (Naumova) Streel 1964 \\ Retusotriletes sp. (SI 353 SM) \\ P1. III, fig. 1.}

Description. Miospores trilete, acavate. Diameter $70 \mu$ and $95 \mu$ (only two specimens). Amb circular, outline irregular due to folding. Suturae labrate, straight, distinct, 0.5 radius of spore. Labra a few $\mu$ high, membraneous. Contact areas depressed and ornamented with irregular, circular to elongated crooked flat elements. Sculptural elements $2-5 \mu$ long, $1.5-2 \mu$ in width and $0.5-1 \mu$ high. The distance apart is appr. twice the width of the elements. Exine outside contact area smooth, laevigate to finely punctate (corrosion?), twolayered. Outer layer (exoexine) $1.5 \mu$ thick, inner layer (intexine) $1 \mu$ thick. The two layers are not seen separated from each other. Exine folded.

Remarks. This species is included in the genus Retusotriletes, although the contact areas are sculptured. Apiculiretusispora STREeL 1964 is characterized 
by a sculptured exine with the ornament reduced or absent on the contact areas. Therefore it seems most reasonable to include the above described spore type in Retusotriletes.

\section{Infraturma Apiculati (BenNiE and Kidston) Potonié 1956 \\ Subinfraturma Granulati DyBova and JACHOWICZ 1957 \\ Genus Granulatisporites (IBRAHIM) POTONIÉ and Kremp 1954 \\ Granulatisporites sp. (Sl 415 SM) \\ Pl. III, figs. 5-6.}

Description. Miospores trilete, acavate. Diameter $41-54 \mu$, mean $47 \mu$ (6 specimens). Amb convexly triangular with rounded apices. Suturae simple, straight, distinct, 0.8-0.9 radius of spore. Contact area may be depressed, but curvaturae are not developed. Exine densely and finely granular. Grana rounded, appr. $0.5 \mu$ in diameter. The ornament may be destroyed in the equatorial region by corrosion. Exine $1.5-2 \mu$ thick, seldom folded.

\section{Genus Cyclogranisporites Potonié and Kremp 1954 \\ Cyclogranisporites cf. commodus PLAYFORD 1963 \\ Pl. III. figs. 2, 7, 8 .}

1967 Cyclogranisporites commodus Playford - Butterworth and SpInner, p. 5; pl. 1, fig. 4.

Description. Miospores trilete, acavate. Diameter $29-50 \mu$, mean $38 \mu$ (10 specimens). Amb circular to broadly convexly triangular with rounded apices. Suturae simple, straight, distinct, 0.7-0.9 radius of spore. Exine more or less distinctly granular (oil immersion may be necessary). Grana flat-topped, with rounded to polygonal outlines, closely spaced, forming a fine negative reticulum. Diameter of grana $0.5-1.5 \mu$. Exine $2 \mu$ thick, frequently folded.

Remarks. C. commodus differs from the above described spores and from the spores described by BUTTERWORTH and SPINNER as C. commodus in its relatively thinner exine $(1 \mu)$. As this difference is rather considerable in view of the size of the spores, complete identity cannot be maintained.

\section{Cyclogranisporites sp. (SI 290 SM) \\ Pl. XVII, figs. 4, 7, 8.}

Description. Miospores trilete, acavate. Diameter 37-61 $\mu$, mean $48 \mu$ (20 specimens). Amb circular to rounded convexly triangular. Suturae simple, straight to sinuous, not always distinct, $0.7-0.9$ radius of spore. Surface of spore covered with minor grana and tubercula, $1 \mu$ in diameter, $1 \mu$ high. Distally they are closely spaced being polygonal in outline. Proximally the ornament 
is absent or reduced. Exine 3.5-4 $\mu$ thick, massive, not folded.

Remarks. This thick walled spore type has an outer resemblance to granulate cingulate forms referred to the genus Stenozonotriletes, e.g. S.? bracteolus (Butterworth and Williams) Smith and Butterworth 1967.

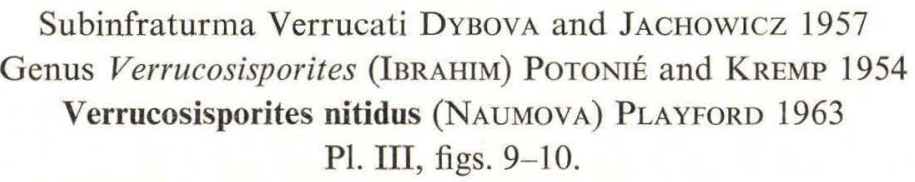

1953 Lophotriletes grumosus NaUmova, p. 57; pl. 7, figs. 14-15.

? 1956 Lophotriletes aff. grumosus NAUMOVA - IschenKo, p. 40; pl. 6, fig. 74.

1963 b Verrucosisporites nitidus Playford, p. 13; pl. 3, figs. 3-6.

? 1964b Verrucosisporites grumosus (NAUMova 1953) Sullivan, p. 1252; pl. 1, figs. 9-15. 1971 Verrucosisporites nitidus (Naumova) Playford - Clayton, p. 592; pl. 4, fig. 7.

Description. Miospores trilete, acavate. Diameter 37-57 $\mu$, mean $42 \mu$ (17 specimens). Amb circular to broadly rounded, convexly triangular. Suturae simple, straight, distinct, $0.7-0.8$ radius of spore. Exine sculpture verrucate. Verrucae flat, rounded polygonal, forming a negative reticulum. Diameter of verrucae $0.5-6 \mu$ (commonly $3-5 \mu$ ). The height is less than $1 \mu$. The size of the sculptural elements is reduced on the proximal surface. Exine $1.5-2.5 \mu$ thick, often folded.

Remarks. The specimens are relatively finely ornamented and they are comparable with Converrucosisporites parvinodosus PlAYFORD 1963b, p. 15; pl. 3, figs. 7-9, a species not clearly defined from $V$. nitidus. Although the sculptural variation within $V$. nitidus is wide, the including of such coarse sculptured types as Lophotriletes aff. grumosus NAUMOVA described by IsCHENKO 1956 and Verrucosisporites grumosus (NAumova) Sullivan 1964b (especially figs. 14-15) is questionable.

Stratigraphical range. Up. Devonian to Viséan.

Geographical distribution.

Europe: Scotland (Clayton 1971), England and Eire (Sullivan 1964b, Dolby 1970, Dolby and Neves 1970, Johnson and Marshall 1971), France (Combaz and Streel 1970), Belgium and Germany (PAProth and StREel 1970).

U.S.S.R.: NAUMOVA (1953), IschenKo (1956).

North America: Canada (Playford 1963b).

Verrucosisporites scoticus SULLIVAN 1968

Pl. IV, fig. 5.

1968 Verrucosisporites scoticus Sullivan, p. 121; pl. 25, figs. 11-12. 
Description. Miospores trilete, acavate. Diameter $30-46 \mu$ (3 specimens). Amb circular to broadly rounded triangular. Suturae simple, straight, covered by the ornament, $0.5-0.6$ radius of spore. Exine ornamented with closely spaced verrucae, frequently united at their bases. Verrucae rounded in profile and in outline. Basal diameter $4-6 \mu$, height $2-3 \mu$. Distance apart of verrucae commonly $1-2 \mu$. Appr. 20 verrucae are counted equatorially. Exine $3-5 \mu$ thick incl. sculpture.

Remarks. A reduction of the ornament on the proximal surface is not observed in the studied specimens, cf. the diagnosis of Sullivan: "ornament mainly confined to distal surface". Otherwise they do not differ from the specimens described by Sullivan.

Stratigraphical range. Tournaisian.

Geographical distribution.

Europe: Scotland (Sullivan 1968).

\section{Verrucosisporites spp.}

Pl. IV, fig. 3.

Remarks. A few specimens recorded take up a morphological intermediate position between Verrucosisporites variotuberculatus Sullivan 1968 and Pustulatisporites multicapitis n. sp. (cf. p. 35). Their knotty verrucate ornament has some resemblance to the sculptural elements of $P$. multicapitis, but the dimensions of the verrucae agree with those of $V$. variotuberculatus. As in the latter species a proximal sculptural reduction is seen. They differ from $V$. variotuberculatus in having a more open sculpture (not polygonal bases). In relation to P. multicapitis the sculpture is too low and closely spaced. Also a proximal reduction is not seen in $P$. multicapitis. Their size range is $54-62 \mu$ excl. sculpture.

Genus Schopfites Kosanke 1950

Schopfites claviger SulLivan 1968

Pl. IV, figs. 4, 6, 7.

1968 Schopfites claviger Sullivan, p. 121; pl. 25, figs. 9-10.

1971 Schopfites claviger Sullivan - Clayton, p. 588; pl. 3, figs. 3-5.

Description. Miospores trilete, camerate. Diameter (excl. sculpture) 34-54 $\mu$, mean $47 \mu$ (20 specimens). Amb circular to oval. Suturae simple, straight to slightly sinuous, rarely visible, $0.5-0.8$ radius of spore. Ornament of closely spaced pila covers the distal surface. Pila $2-5 \mu$ high (commonly $3 \mu$ ). Heads of pila $1-2 \mu$ in diameter. Proximal surface devoid of ornament. Exoexine coarsely infrapunctate, less than $1 \mu$ thick, commonly folded. The structure of the exoexine (including the pila) seen in the S.E.M. is spongy. Intexine thin, difficult to observe due to the non-transparency of the exoexine. 
1967 Anaplanisporites baccatus (Hoffmeister, Staplin and Malloy) - SMith and ButterWORTH, p. 166 ; pl. 7, figs. $1-5$.

1971 Anaplanisporites baccatus (Hoffmeister, Staplin and Malloy) SMith and ButterWORTH-Clayton, p. 579; pl. 1, figs. 1-2.

Description. Miospores trilete, acavate. Diameter 24-30 $\mu$, mean $27 \mu$ (28 specimens). Amb circular to broadly rounded triangular with rounded apices. Suturae simple to labrate, straight, frequently indistinct, almost equal to spore radius. When labrate, labra very fine and membraneous, less than $1 \mu$ high. Distal surface, equatorial region and a $1-2 \mu$ broad concentric zone of proximal surface ornamented with closely spaced coni or bacula, rounded or truncate. The dimensions of elements vary from $0.5 \times 0.5 \mu$ to $1 \times 1 \mu$. Their bases are circular to polygonal. Their distance apart is less than or equal to diameter of bases. Contact areas smooth or with scattered small grana. The exine of the contact areas is very thin and is often deformed by secondary pyrite crystals. The remaining part of the exine is thicker and more rigid, but less than $1 \mu$ thick. As the thick part of the exine continues on to the proximal surface, a dark equatorial zone is seen in transmitted light, but this must not be mistaken for a cingulum (cf. pl. VI, fig. 4). Curvaturae are not seen in the S.E.M. and the change in exine thickness is believed to be even.

Remarks. Compared with the holotype the above described specimens are sculptured more finely and densely. The ornamentation of this species seems to vary a good deal and more variants have been described (STAPLIN 1960, Kalibova 1971). Anaplanisporites sp. (SI $302 \mathrm{SM}$ ), described below, is possibly a variety of $A$. baccatus.

Stratigraphical range. Tournaisian to Westphalian.

Geographical distribution.

Europe: Scotland (Love 1960, Sullivan and Marshall 1966, Clayton 1971), England (Butterworth and Williams 1958, Smith and ButterWORTh 1967, Llewellyn, Backhouse and Hoskin 1969, Marshall and Williams 1970), Poland (Jachowicz 1967), Czechoslovakia (Kalibova 1971).

North America: U.S.A. (Hoffmeister, Staplin and Malloy 1955), Canada (Staplin 1960).

\section{Anaplanisporites sp. (SI 302 SM) \\ Pl. V, fig. 8; pl. VI, figs. 5-6.}

Description. Miospores trilete, acavate. Diameter $27-36 \mu$ (7 specimens). Amb broadly rounded triangular with rounded apices. Suturae simple, straight, $0.8-1$ radius of spore. Distal surface and equatorial region ornamented with fine, closely spaced grana, with rounded or polygonal bases. Grana $0.5 \times 0.5 \mu$ to $0.7 \times 0.7 \mu$. Contact areas unsculptured. Exine thin, especially in the contact 
areas. Curvaturae not present.

Remarks. The typical granular ornament and the size are the criteria used to distinguish this spore type from A. baccatus, which is characterized by a microbaculate to microconate ornament. It may probably be regarded as a variety of $A$. baccatus.

\section{Anaplanisporites? cf. globulus (BUtTERWORTH and WiLLIAMs) \\ SMith and ButTERWORTH 1967 \\ Pl. V, fig. 10.}

Remarks. Two specimens probably referable to A. globulus were recorded. They differ from the type material (re-studied by SMITH and ButTerworth 1967) by the occurrence of a reduced proximal ornament. They are only tentatively included in Anaplanisporites, a genus characterized by laevigate contact areas. A. globulus is restricted to Upper Viséan? and Lower Namurian deposits in Great Britain (Smith and Butterworth 1967, Marshall and WiLLiams 1970).

\section{Genus Pustulatisporites Potonié and Kremp 1954 \\ Pustulatisporites multicapitis n. sp. \\ Pl. VII, figs. 1-6; text-fig. 7.}

Holotype. Pl. VII, fig. 4; Sl 273 SM. Diameter $63 \mu$ (excl. sculpture).

Type locality. Ørslev No. 1 borehole, D.G.U. file No. 238.502.

Type stratum. Marlstone, black-grey. Borehole depth $7743^{\prime} 0^{\prime \prime}$. Lower. Viséan

Derivation of name. Of multus (lat.) = much and caput (lat.) $=$ head.

Diagnosis. A Pustulatisporites species ornamented with relatively coarse, mammiliform, conate extensions with characteristic expanded, "knotty" heads. Diameter (excl. sculpture) 48-75 . Amb circular to broadly, convexly triangular. Suturae simple, straight, $0.5-0.7$ radius of spore. Exine $2-4 \mu$ thick. Appr. 15-30 elements, commonly 6-7 $\mu$ high, project from the margin.

Description. Miospores trilete, acavate. Diameter $48-75 \mu$, mean $60 \mu$ (25 specimens). Amb circular to broadly, convexly triangular with rounded apices. Proximal and distal profiles originally convex. Suturae simple, straight, normally distinct, 0.5-0.7 radius of spore. Proximal and distal surfaces sculptured with conate to mammiliform, smooth to knotty extensions. The heads of the elements formed by constrictions are characteristically subdivided into two or more semiglobular parts on most specimens (e.g. pl. VII, figs. 1-2). Some elements have simple heads. Other elements are formed like rounded, knotty coni and verrucae (pl. VII, figs. 5-6). The height of the sculpture is commonly 6-7 $\mu$, but may reach $9 \mu$. The bases of the elements are rounded, commonly $7-8 \mu$ in diameter, but when elongated they may be up to $12 \mu$. Whereas the height of the sculpture seems to be rather constant in single specimens, the $3 *$ 


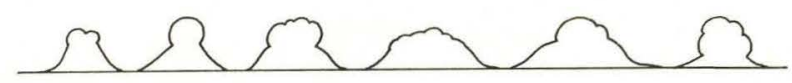

Text-fig. 7: The ornament types of P. multicapitis n. sp. $\times 1000$.

diameter of the bases varies. Generally, specimens with wide elements bear few, specimens with narrow elements many of these. The number of extensions projecting from the equator is approximately 15-30. The surface of the exine may be smooth or covered by grana between the elements. Exine $2-4 \mu$ thick (excl. sculpture).

Comparison and discussion. Pustulatisporites gibberosus (HACQUeBard) PLAYFORD 1963b (p. 18; pl. 3, figs. 18-20) differs from P. multicapitis n. sp. by its sculptureless contact area and more simple ornament types. The sculpturing elements of Raistrickia ponderosa Playford 1963b (p. 25; pl. 6, figs. 11-12; pl. 7, fig. 1) are closer spaced, and their basal parts are cylindrical rather than conate. The number of elements per spore is larger and the elements are more uniform than those found in $P$. multicapitis. The species is assigned to the genus Pustulatisporites since the sculpturing elements are not closely spaced and are of mixed conate verrucate type. It is not to be referred to either Verrucosisporites or Raistrickia.

\section{Genus Apiculatisporites (IвrAhim) Smith and Butterworth 1967 Apiculatisporites sp. (SI 238 SM) \\ Pl. IV, figs. 1-2.}

Description. Miospores trilete, acavate. Diameter $78-108 \mu$ (4 specimens). Suturae simple, indistinct (covered by ornament), 0.4-0.6 radius of spore. Exine evenly or unevenly ornamented with low, more or less rounded coni, which are often united at their bases. Coni $1-2 \mu$ high, $1-4 \mu$ in diameter. Exine $2 \mu$ thick (excl. sculpture), folded on the recorded specimens.

Genus Acanthotriletes (Naumova) Potonié and Kremp 1954

Acanthotriletes spinosus (NAUmova) IsCHENKo 1956

Pl. VIII, figs. 6,8 .

1938 Azonotriletes spinosus (Naumova) Waltz in Luber and Waltz, p. 13; pl. 1, fig. 13; pl. 5, fig. 62.

1956 Acanthotriletes spinosus NAUMOVA - IschenKo, p. 28; pl. 4, figs. 39-41.

1958 Acanthotriletes spinosus NAUMOVA - IsCHENKo, p. 45; pl. 3, figs. 33-36.

? 1963 Acanthotriletes dominans KEDo, p. 43; pl. 2, figs. 53-54.

? 1966 Acanthotriletes dominans KEDo, p. 55; pl. 1, figs. 34-35.

Description. Miospores trilete, acavate. Diameter $39-50 \mu$, mean $44 \mu$ (11 specimens). Amb circular to oval. Proximal and distal surfaces semiglobular. Suturae (only observed in one specimen) simple, straight, (0.6 radius of spore). Exine ornamented with evenly distributed, somewhat irregular spinae and coni, 
$0.5-2 \mu$ high (commonly $1.5 \mu$ ), with rounded bases $0.5-1 \mu$ in diameter. Distance apart of elements $1-5 \mu$, commonly $1-2 \mu$. Exine thin (less than $1 \mu$, non-measurable), folded, structureless.

Remarks. Acanthotriletes dominans KEDO 1963 is possibly identical with A. spinosus (Naumova) Ischenko, but the identity cannot be established on the basis of the descriptions and figures published.

Stratigraphical range. Devonian to Namurian.

Geographical distribution.

U.S.S.R.: Recorded from various parts of the Soviet Union by LUBER and WALtZ (1938), IschenKo $(1956,1958)$ and Kedo? $(1963,1966)$.

Genus Apiculiretusispora Streel 1964

Apiculiretusispora multiseta (LUBER) BUTTERWORTH and SPINNER 1967

Pl. VIII, figs. 5, 7.

1938 Azonotriletes multisetus LUber in LUber and WAltz, p. 23; pl. 5, fig. 61.

1962 Acanthotriletes multisetus (Luber) Potonié and KremP - PlayFord, p. 590; pl. 80, figs. 14-15.

1963 Acanthotriletes multisetus (LuBER) KEDO, p. 43; pl. 2, figs. 51-52.

1966 Acanthotriletes multisetus (LUBER) KEDO - KEDO, p. 56; pl. 1, figs. 36-38.

1967 Apiculiretusispora multiseta (Luber) BUtTerworth and SPINnER, p. 5; pl. 2, figs. 13, 18.

1967 Acanthotriletes multisetus (Luber) Potonié and KremP - BARss, pl. 7, fig. 17.

1970 Apiculiretusispora multiseta (Luber 1938) Butterworth and SPINNer - Kaiser, p. 93 ; pl. 18, fig. 7.

Description. Miospores trilete, acavate. Diameter 34-54 $\mu$, mean $41 \mu$ (27 specimens). Amb circular to oval. Suturae simple, indistinct, more than half the radius of spore. Exine ornamented with closely spaced spinae, straight to crooked, commonly $1.5-2 \mu$ high. Studied on the S.E.M. the spinae sometimes seem to be rounded bacula rather than spinae. Ornament may be reduced on the proximal surface. Exine thin, less than $1 \mu$, commonly folded and partly destroyed by secondary pyrite crystals.

Remarks. Curvaturae have not been observed in a convincing way. Otherwise the above described specimens conform with the descriptions given by the authors in the synonym list. One specimen was found to be camerate and probably more careful studies may show, that some of the specimens must be referred to Tholisporites cf. decorus Bharadwaj and Venkatachala; Neves and IoAnnides (in press) as described by Clayton (1971, p. 590).

Stratigraphical range. (Devonian?) Tournaisian to Viséan.

Geographical distribution.

Europe: Scotland (Love 1960), England (Butterworth and Spinner 1967).

U.S.S.R.: Luber and Waltz 1938, Kedo 1957, 1963, 1966. 
Arctic region: Spitsbergen (PLAYFORD 1962), Bear Island (KAISER 1970).

North America: Canada (BARss 1967).

A variety has been described from the Middle Old Red Sandstone deposits of the Orcadian Basin of Scotland by Richardson (1965, p. 566). This variety is larger (over $60 \mu$ ) than A. multiseta and the extension of the stratigraphical range of $A$. multiseta to the Devonian is therefore questionable.

\section{Apiculiretusispora sp. (SI 304 SM)}

Pl. VIII, figs. 2-4.

Description. Miospores trilete, acavate. Diameter 69-77 $\mu$ (5 specimens). Amb circular to broadly, convexly triangular with rounded apices. Suturae simple, straight, indistinct, $0.6-0.8$ radius of spore. Curvaturae present, approximately merging with the inner borderline of the exine, when studied in optical section. Contact areas laevigate to scabrate. Remaining part of the exine densely ornamented with grana and stout bacula or pila, $0.5-3 \mu$ high, $1 \mu$ in diameter. Exine 4-5 $\mu$ thick measured at the equator.

Remarks. It has not been possible to find descriptions of species comparable to the above described spore type. The majority of species of the genus Apiculiretusispora seem to be restricted to Devonian stages.

\section{Subinfraturma Baculati Dybova and JACHOwicz 1957 \\ Genus Baculatisporites Thomson and Pflug 1953 \\ Baculatisporites fusticulus SULLIVAN 1968 \\ Pl. III, figs. 3-4.}

1968 Baculatisporites fusticulus Sullivan, p. 117; pl. 25, figs. 1-2.

1971 Baculatisporites fusticulus Suldivan - Clayton, p. 580; pl. 1, fig. 4.

Description. Miospores trilete, acavate. Diameter $63-90 \mu$, mean $76 \mu$ (9 specimens). Amb circular to oval. Suturae simple, straight to sinuous, often indistinct, $0.5-0.7$ radius of spore. Exine evenly and densely granular to microbaculate. Grana and bacula (rounded) commonly $1 \mu$ high and less than $1 \mu$ in diameter. Densely spaced elements may have polygonal bases, otherwise the bases are circular. Exine 1-1.5 $\mu$ thick, frequently folded.

Remarks. The specimens studied have a lower type of ornament, than the spores described by SULLIVAN and CLAYTON. This is partly ascribed to secondary corrosion phenomena, since several of the observed specimens have bare, sculptureless, corroded areas.

Stratigraphical range. Tournaisian.

Geographical distribution.

Europe: Scotland (Sullivan 1968, Clayton 1971), England (Llewellyn, Backhouse and Hoskin 1969, Johnson and Marshall 1971), BelgiumGermany (STREEL 1970). 


\title{
Baculatisporites sp. (SI 243 SM)
}

\author{
Pl. IX, figs. 6-7.
}

Remarks. A few specimens referable to the genus Baculatisporites have been recorded. Most of them have short, more or less cylindrical bacula as shown in the scanning micrograph (pl. IX, fig. 7).

\author{
Genus Raistrickia Schopf, Wilson and Bentall 1944 \\ Raistrickia corynoges Sullivan 1968 \\ Pl. IX, figs. 1, 4.
}

1963 Acanthotriletes macrurus (Luber) Naum. - Kedo, p. 44; pl. 3, fig. 57.

1963 Acanthotriletes sphaerites Kedo, p. 44; pl. 3, fig. 58.

1964 b Raistrickia sp. A. Sullivan, p. 1252; pl. 1, fig. 8.

1968 Raistrickia corynoges Sullivan, p. 119; pl. 25, figs. 6-8; text-fig. 2.

1970 Raistrickia corynoges Sullivan - Combaz and Streel, p. 232; pl. 4, figs. 12-13.

1971 Raistrickia corynoges Sullivan - Clayton, p. 587; pl. 3, fig. 1.

Description. Miospores trilete, acavate. Diameter (excl. sculpture) 65-85 $\mu$, mean $74 \mu$ (21 specimens). Amb circular. Suturae simple or faintly labrate, indistinct in transmitted light, straight, more than half radius of spore in length. Ornament baculate. Bacula $10-15 \mu$ high, $2-6 \mu$ or even more in diameter. In horizontal section they are rounded, circular to elongated oval. The tops are rounded, truncate or composed of a row of smaller extensions formed by bifurcation of the outer part of the bacula. At their bases the bacula are connected by flanges of $2-3 \mu$ broad muri. The profiles of the connections forming a more or less perfect reticulum with the bacula situated at the connection points, are concave. The lumina of the network are cup-shaped. The complexity of the ornament has a wide variation and is demonstrated in the scanning micrographs (pl. IX, figs. 1 and 4), which also show the sporadic reduction of bacula to rounded coni. Exine otherwise laevigate, $2-3 \mu$ thick measured in the centers of lumina.

Remarks. The spores are generally larger than those described by Sullivan, which have a size range from 50-(64)-75 $\mu$. A proximal reduction of the ornament is not marked on well preserved specimens. Compressed specimens may have a polar reduction caused by breakage of the massive elements (an ultragranular spongy mass is seen in the interior of the broken bacula in the S.E.M.), but this reduction is secondary.

Acanthotriletes sphaerites KEDO 1963 is in the author's opinion only a variety of $R$. corynoges and it is therefore included in the synonym list.

Stratigraphical range. Tournaisian.

Geographical distribution.

Europe: Scotland (Sullivan 1968, Clayton 1971), England (Sullivan 1964b, Utting and Neves 1970, Johnson and Marshall 1971), France (Combaz and Streel 1970), Belgium-Germany (Streel 1970).

U.S.S.R.: Kedo 1963, not Luber and WALtz 1938. 


\section{Raistrickia nigra LOVE 1960}

Pl. IX, figs. 2-3.

1960 Raistrickia nigra Love, p. 114; pl. 1, fig. 5; text-fig. 4.

1966 Raistrickia nigra LOVe - Sullivan and Marshall, p. 269; pl. 1, figs. 27-28.

1968 Raistrickia nigra Love - Neville, p. 436; pl. 1, fig. 2.

1969 Raistrickia nigra LOVE - HIBBERT and LACEY, p. 424; pl. 78, figs. 5-6.

Description. Miospores trilete, acavate. Diameter (excl. sculpture) 45-58 $\mu$ (3 specimens). Amb convexly triangular with rounded apices. Suturae simple, straight, distinct, $0.7-0.8$ radius of spore. Exine sculptured with bacula or coni, rounded, sometimes obliquely truncated. Elements 4-7 $\mu$ high, 4-5 $\mu$ in diameter. Bases circular. Distance apart $1-2 \times$ the diameter of elements. Proximal ornament reduced or missing. 16 and 21 extensions along the margin on two specimens. Exine otherwise laevigate, $3 \mu$ thick.

Remarks. Specimens conform with the original diagnosis of LOVE, but are slightly smaller than originally stated for this species $(60-75 \mu)$. They fall within the size ranges given by Sullivan and Marshall (1966) and Neville (1968). A proximal reduction of sculpture is not mentioned by Love, but noted by Sullivan and Marshall ("Ornamentation ... mainly confined to the distal surface"' (p. 270)).

Stratigraphical range. Viséan.

Geographical distribution.

Europe: Scotland (Love 1960, Sullivan and Marshall 1966, Neville 1968), England (HiBBERT and LACEY 1969).

\section{Genus Umbonatisporites (HIBBERT and LACEY) CLAYTON 1971 Umbonatisporites distinctus CLAYTON 1971 \\ Pl. VIII, fig. 1.}

1971 Umbonatisporites distinctus Clayton, p. 591; pl. 4, figs. 4-6.

Description. Miospores trilete, acavate. Diameter (excl. sculpture) 33-54 $\mu$ (2 specimens). Amb circular. Suturae, simple, straight, indistinct, 0.3 radius of spore. Contact area corroded, without ornament. Exine otherwise evenly ornamented with 6-7 $\mu$ high, subcylindrical bacula, $2 \mu$ in basal diameter, but tapering to $1 \mu$ at the top. A collar with a central 1-2 $\mu$ long spina terminates the elements. Distance apart of the elements is equal to their height. Exine otherwise laevigate, less than $1 \mu$ thick, folded.

Remarks. The characteristic ornament of the spores corresponds closely to the original description of Clayton.

Stratigraphical range. Tournaisian.

Geographical distribution. Hitherto only recorded from Scotland. 
Infraturma Murornati PotoNiÉ and KREMP 1954

Genus Convolutispora Hoffmeister, StaPlin and Malloy 1955

Convolutispora amplecta (LUBER) JACHOWICZ $1967 \mathrm{f}$. kasachstanensis LUBER

Pl. X, figs. 1-2.

1938 Azonotriletes amplectus, forma kasachstanensis LUBER in LUBER and WALTZ, p. 25; pl. 5, fig. 71.

1967 Convolutispora amplecta (LUBER) f. kasachstanensis (LUBER) JACHOWICZ, p. 29; pl. 15, figs. 2-5.

Description. Miospores trilete, acavate. Diameter $48-82 \mu$, mean $62 \mu$ (18 specimens). Amb circular to irregular oval. Suturae simple, covered by ornament, straight, half the radius of spore in length. Exine ornamented with muri, 2-5 $\mu$ wide and 1-4 $\mu$ high, rounded in profile, partly anastomosing forming an irregular reticulum. Lumina long, irregular and usually narrow. Their width is approximately the width of the surrounding muri, on average. Exine otherwise laevigate, $2.5-3 \mu$ thick measured in the centers of lumina.

Remarks. The size range of specimens is greater than stated by LUBER $(70-80 \mu)$. The measurements of JACHOwICZ (1967) show a corresponding width of the size range, but the values are slightly higher (58-78.5-92 $\mu$ ). The spores figured by IsCHENKo (1956, pl. 7, figs. 92-94) as Periplecotriletes amplectus $\mathrm{f}$. kasachstanensis seem to have a wide morphological span of variation. Only fig. 94 agrees with the author's opinion of the variety kasachstanensis.

Stratigraphical range. Tournaisian to Viséan.

Geographical distribution.

Europe: Poland (JACHOWICZ 1967).

U.S.S.R.: LUBER and WALTZ 1938, IsCHENKo 1956.

\section{Convolutispora circumvallata CLAYTON 1971}

Pl. XIV, figs. 5-6.

1971 Convolutispora circumvallata Clayton, p. 582; pl. 1, figs. 5-7.

Description. Miospores trilete, acavate. Diameter $73-90 \mu$ (3 specimens). Amb circular to oval. Suturae simple, straight, partly covered by ornament, more than half radius of spore in length. Exine ornamented with an irregular, imperfect reticulum of muri $2-11 \mu$ in width, up to $7 \mu$ high. Muri more or less mushroom-shaped in transverse section. Reduced muri may form isolated cylindrical elements. Lumina and ornament-free part of exine constitute approximately $50 \%$ of the surface of spore. The height of the sculpture decreases towards the proximal pole. Exine $7-11 \mu$ thick including the ornament.

Remarks. The sculpturing of this species is extremely variable. The above described specimens are most in accordance with fig. 6 of CLAYTON (1971).

Stratigraphical range. Tournaisian.

Geographical distribution. Hitherto only recorded from Scotland. 


\section{Convolutispora aff. crassa PLAYFORD 1962 \\ Pl. X, fig. 6.}

Description. Miospores trilete, acavate. Diameter 44-68 $\mu$ (3 specimens). Amb circular. Suturae simple, straight, 0.6-0.8 radius of spore. Exine ornamented with muri, 3-4 $\mu$ high, $2-5 \mu$ in width and flat-topped. Muri anastomosing, forming an imperfect reticulum. Lumina narrow, long, irregular, commonly having a width of approximately $1 \mu$. Exine $6-9 \mu$ thick (incl. sculpture).

Remarks. Specimens conform with the diagnosis of PLAYFORD (1962), except for the size range. They are smaller than stated by PLAYFORD (61-85-115 $\mu$ ).

Stratigraphical range. Tournaisian to Viséan.

Geographical distribution.

Arctic region: Spitsbergen (PLAYFORD 1962).

U.S.S.R.: For possible records cf. PLAYFORD (1962).

\section{Convolutispora densorugosa $\mathbf{n}$. sp. Pl. XII, figs. 5-7.}

Holotype. P1. XII, fig. 5; S1 254 SM. Diameter $88 \mu$.

Type locality. Ørslev No. 1 borehole, D.G.U. file No. 238. 502.

Type stratum. Marlstone, black-grey. Borehole depth $7716^{\prime} 0-7^{\prime \prime}$. Lower Viséan.

Derivation of name. Of densus (lat.) $=$ dense and rugosus (lat.) $=$ wrinkled.

Diagnosis. A Convolutispora species characterized by an ornament of closely packed, wrinkled muri, $1-5 \mu$ in width and up to $3 \mu$ high and rounded triangular in transverse section. Diameter 84-111 $\mu$. Amb circular to broadly, convexly triangular with rounded apices. Suturae straight to sinuous, 0.5-0.7 radius of spore. Exine 7-10 $\mu$ thick (incl. sculpture), distinctly two-layered, the layers being not separated. Inner layer (intexine) $2 \mu$ thick, infrapunctate.

Description. Miospores trilete, acavate. Diameter 84-111 $\mu$, mean $90 \mu$ (13 specimens). Amb circular to broadly, convexly triangular with broadly rounded apices. Suturae simple, straight to slightly sinuous, distinct, partly covered by ornament, $0.5-0.7$ radius of spore. Exine ornamented with closely packed, wrinkled muri, $1-5 \mu$ wide and up to $3 \mu$ high. Muri rounded, more or less triangular in transverse section. The ornament is modified along the suturae, which are not "crossed" by the muri. Double rows of muri mark the position of suturae (pl. XII, fig. 7), but they are not interpreted as labra. Exine 7-10 $\mu$ thick (incl. sculpture), distinctly two-layered. The two layers are not separated from each other. Inner layer (intexine) $2 \mu$ thick, infrapunctate.

Comparison. C. densorugosa shows a sculptural resemblance to Convolutispora finis Love 1960 (p. 115; pl. 1, fig. 7 and text-fig. 5). They have approximately the same size range (C. finis: $85-110 \mu$ ), but the ornament of the latter is lower 
and more rounded and the exine is thinner ( $4-5 \mu$ incl. sculpture). C. ampla Hoffmeister, Staplin and Malloy 1955 (p. 384; pl. 38, fig. 12) is smaller than $C$. densorugosa and the sculpture is more open with recognizable lumina ("depressions").

Convolutispora finis Love 1960

Pl. II, fig. 6.

1960 Convolutispora finis Love, p. 115; pl. 1, fig. 7; text-fig. 5.

Description. Miospores trilete, acavate. Diameter $55-80 \mu$ (5 specimens). Amb circular. Suturae simple, straight, distinct, 0.6-0.8 radius of spore. Ornament vermiculate. Vermiculi approximately $1 \mu$ deep, form an irregular imperfect reticulum. Muri rounded, $1-2 \mu$ wide. Exine $2-4.5 \mu$ thick, with arcuate folds.

Remarks. The above described specimens are identical with $C$. finis although their diameter is smaller than stated by Love (1960) cf. the preceding description. The figured specimen has been compared with the holotype of $C$. finis stored in Sheffield. Punctatisporites parvivermiculatus PLAYFORD 1962 (p. 577; pl. 78, fig. 14) has a much finer, but comparable sculpture.

Stratigraphical range. Viséan.

Geographical distribution. Hitherto only recorded from Scotland. Comparable but not identical forms are described by PLAYFORD (1963b) and BUTTERWORTH and SPINNER (1967).

Convolutispora turgida $\mathrm{n}$. sp.

Pl. XI, figs. 3, 5 .

Holotype. Pl. XI, fig. 3; S1 319 SM. Diameter $133 \mu$.

Type locality. Ørslev No. 1 borehole, D.G.U. file No. 238.502.

Type stratum. Marlstone, black-grey. Borehole depth 7739'4-9'. Lower Viséan.

Derivation of name. Of turgidus (lat.) $=$ turgid.

Diagnosis. A Convolutispora species characterized by an ornament of "turgid", partly anastomosing muri, distally $10-20 \mu$ in width, semicircular in transverse section, proximally reduced. Lumina irregular, narrow and subordinate. Diameter $81-150 \mu$. Amb convexly triangular with broadly rounded apices. Suturae simple or with minor raised labra, straight, not covered by ornament, almost equal to the radius of the spore body. Exine commonly $15-20 \mu$ thick (not exceeding $25 \mu$ ) measured in the equatorial region (and incl. sculpture).

Description. Miospores trilete, acavate. Diameter 81-150 $\mu$, mean $118 \mu$ (17 specimens). Amb convexly triangular with broadly rounded apices. Suturae simple or with minor raised labra, straight, distinct, not covered by ornament, 
almost equal to the radius of the spore body. Exine ornamented with a coarse, convolute sculpture. Muri rounded with semicircular profile in transverse section, sinuous, variable in width and height, partly anastomosing, partly united in platelike thickenings. Lumina narrow, irregular, subordinate to muri in width. Proximal ornament with reduced dimensions. Proximal width of muri about $10 \mu$; distal width commonly between 10 and $20 \mu$. Exine commonly $15-20 \mu$ (not exceeding $25 \mu$ ) measured in the equatorial region (and incl. sculpture).

Remarks. The author has failed in the search for Convolutispora species which could be mistaken for $C$. turgida or could be referred to this.

\section{Convolutispora vermiformis HugheS and PLAYFORD 1961}

Pl. XI, fig. 2.

1961 Convolutispora vermiformis Hughes and PLAYFord, p. 30; pl. 1, figs. 2-4.

1962 Convolutispora vermiformis Hughes and Playford - Playford, p. 593; pl. 82, figs. 5-6.

1963b Convolutispora vermiformis Hughes and Playford - Playford, p. 27; pl. 7, figs. 8-9.

1967 Convolutispora vermiformis Hughes and PLAYFord - Felix and BURBridge, p. 374; pl. 57 , figs. 5 .

1969 Convolutispora vermiformis Hughes and Playford - HibBert and Lacey, p. 425; pl. 79, figs. 6-7.

1970 Convolutispora vermiformis Hughes and Playford - Kaiser, p. 95; pl. 18, figs. 14-16.

Description. Miospores trilete, acavate. Diameter $67-74 \mu$ (3 specimens). Amb circular to broadly rounded triangular. Suturae simple, straight, 0.6-0.7 radius of spore. Exine ornamented with a reticulum formed by rounded muri, 5-8 $\mu$ in width, up to $5 \mu$ high, sinuous. Lumina irregular to polygonal. The width of lumina is equal to the width of the surrounding muri or (commonly) larger. Exine 2-7 $\mu$ thick (incl. sculpture).

Stratigraphical range. Tournaisian to Viséan. Namurian?

Geographical distribution.

Europe: England (Hibbert and Lacey 1969, Llewellyn, BaCKhouse and Hoskin 1969, Mortimer, Chaloner and Llewellyn 1970, Johnson and Marshall 1971).

Arctic region: Spitsbergen (Hughes and Playford 1961, Playford 1962), Bear Island (KAISER 1970).

North America: U.S.A. (Felix and Burbridge 1967), Canada (Playford 1963b).

Convolutispora cf. vermiformis HUGHES and PLAYFORD 1961 Pl. XI, fig. 4.

Remarks. In addition to the spores which are identified with $C$. vermiformis some smaller specimens $(34-41 \mu)$ have been noticed. Their sculpture resembles 
that of $C$. vermiformis, but it is too coarse in relation to their size. They are also too small to be referred to C. vermiformis, the lower size limit of which is about $40 \mu$. C. florida Hoffmeister, Staplin and Malloy 1955 (p. 384; pl. 38, figs. 5-6) has a more complex, not so coarse type of ornament, but the size (39-50 $\mu$ ) is comparable.

\section{Convolutispora sp. (SI 227 SM) \\ Pl. X, fig. 7; Pl. XI, fig. 1.}

Description. Miospores trilete, acavate. Diameter $86-95 \mu$ (6 specimens). Amb circular to subcircular. Suturae simple, straight, covered by ornament, $0.6-0.8$ radius of spore. Exine ornamented with muri $3-8 \mu$ in width, $3-4 \mu$ in height, rounded, partly anastomosing, sinuous. Lumina irregular, narrow, furcate, not exceeding the surrounding muri in width. Exine $7-11 \mu$ thick (incl. sculpture).

Remarks. C. mellita Hoffmeister, Staplin and Malloy 1955 (p. 384; pl. 38, fig. 10) differs from $C$. sp. (S1 $227 \mathrm{SM})$ by its smaller size $(60-85 \mu)$ and finer sculpture. C. usitata PlAYFORD 1962 (p. 595; pl. 82, figs. 4, 7, 8) has a more dense, fine sculpture, but a comparable size $(84-112 \mu)$.

\section{Convolutispora sp. (SI 222 SM)}

Pl. X, figs. 3-5.

Description. Miospores trilete, acavate. Diameter $64-82 \mu$ (8 specimens). Amb circular to convexly triangular with broadly rounded apices. Suturae simple, straight, commonly not covered by ornament, $0.5-0.8$ radius of spore. Exine ornamented with muri $2-8 \mu$ (commonly $3-5 \mu$ ) in width, $2-3 \mu$ in height, forming a reticulum with narrow meshes. Minor transverse grooves or wrinkles are seen on the flanks of the muri (cf. pl. X, figs. 3, 5). Lumina narrow, rounded, proximally elongated, seldom more than $2 \mu$ wide. Suturae are situated in a Y-formed system of united, narrow lumina and may be partly covered by the ornament. Towards the distal pole the lumina decrease in diameter on most specimens. Exine 4-8 $\mu$ thick (incl. sculpture). The thickness increases gradually towards the distal pole.

Remarks. Specimens possibly conform with C. mellita Hoffmeister, STAPLin and Malloy 1955, but an identification based on the original description and illustration is not possible. C. cf. usitata Playford described by SMITH and Butterworth (1967, p. 188; pl. 9, figs. 7-8) is also comparable. The characteristic reduction of lumina towards the distal pole observed on the above described specimens is not mentioned in the descriptions of the two species in question. 


\section{Genus Dictyotriletes (Naumova) Smith and Butterworth 1967 \\ Dictyotriletes cancellatus (WALTZ) POTONIÉ and KrEMP 1955 \\ Pl. XV, fig. 1 .}

1938 Azonotriletes cancellatus Waltz in Luber and Waltz, p. 13; pl. 1, fig. 8; pl. 5, fig. 73.

1955 Dictyotriletes (Azonotriletes) cancellatus (Waltz) PotoniÉ and Kremp, p. 108.

1956 Dictyotriletes cancellatus (WALtz) Ischenko, p. 45; pl. 7, figs. 88-89.

1957 Reticulatisporites varioreticulatus HACQUEBARD and BARSS, p. 17; pl. 2, figs. 15-16.

1958 Dictyotriletes cancellatus (WALtz) Ischenko - Ischenko, p. 55; pl. 5, fig. 63.

1961 Corbulispora (Azonotriletes) cancellatus (Waltz) BharadwaJ and Venkatachala, p. 24.

1962 Reticulatisporites cancellatus (WALtz) Playford, p. 597; pl. 82, figs. 11-13; pl. 83, fig. 1-2.

1963 Dictyotriletes cancellatus (WALtz) IschenKo - Kedo, p. 54; pl. 4, fig. 93.

1967 Reticulatisporites cancellatus (WALTZ) PLAYFORD - JACHOWICZ, p. 30; pl. 16, fig. 6; pl. 17, fig. 1 .

1969 Dictyotriletes cancellatus (WALtZ) Potonié and Kremp - HibBert and Lacey, p. 427; pl. 79 , fig. 11.

Description. Miospores trilete, acavate. Diameter 62-146 $\mu$ (11specimens). Amb circular to polygonal. Suturae labrate, straight to slightly sinuous, $0.6-0.9$ radius of spore. Labra developed as flat thickenings with slightly lobate borderlines. Width of labra (single labrum) 4-7 $\mu$. Exine ornamented with a coarsemeshed reticulum with more or less polygonal meshes. Muri rounded, parallelsided, smooth, 2-6 $\mu$ wide, 3-8 $\mu$ high, but uniform within the single specimen. Width of lumina exceeds the width of muri several times. Exine otherwise laevigate, $2-3 \mu$ thick measured in the centers of the lumina.

Remarks. D. cancellatus is presumedly conspecific with $D$. subalveolaris (Luber) Potonié and Kremp 1955, cf. the discussions in Butterworth and SPinNer (1967) and Dolby and Neves (1970).

Stratigraphical range. Up. Devonian to Viséan.

Geographical distribution (incl. D. subalveolaris).

Europe: Scotland (Love 1960, Clayton 1971), England (Sullivan 1964a and b, Butterworth and Spinner 1967, Neves and Dolby 1967, Hibbert and Lacey 1969, Dolby and Neves 1970, Utting and Neves 1970, JohnSON and Marshall 1971), Eire (Dolby 1970), Belgium-Germany (Streel 1970), Poland (JACHOWICZ 1967).

U.S.S.R.: LubER and WALtz 1938, IschenKo 1956, 1958; Kedo 1963.

Arctic region: Spitsbergen (PLAYFORD 1962).

North America: Canada (HaCquebard and Barss 1957, Barss 1967).

Dictyotriletes cheveriensis (PLAYFORD 1963) comb. nov. Pl. XIV, figs. 1-3.

1963b Reticulatisporites cheveriensis PlAYFord, p. 30; pl. 9, figs. 1-3. 
Description. Miospores trilete, acavate. Diameter $66-78 \mu$ (4 specimens). Amb circular to oval. Suturae simple, straight, often obscured by ornament, more than half of the spore radius in length. Exine bears imperfect reticulate sculpture. Muri thin, membraneous, 4-6 $\mu$ high. Lumina irregular and angular, commonly about $10-15 \mu$ wide. Exine $1.5-2.5 \mu$ thick, laevigate.

Remarks. Specimens are small compared with the size range quoted by PLAYFORD (1963b) as 69-(103)-130 $\mu$. The occurrence of larger specimens in the original samples is confirmed by fragments in the slides studied. Reticulatisporites type B of Love (1960, p. 117; pl. 1, fig. 11 and text-fig. 7) has a much coarser sculpture than $D$. cheveriensis. It is identical with Dictyotriletes pactilis Sullivan and Marshall 1966 and is not comparable with $D$. cheveriensis as suggested by PLAYFORD.

Stratigraphical range. Tournaisian.

Geographical distribution. Hitherto only recorded from Canada.

Dictyotriletes membranireticulatus $\mathbf{n}$. sp.

Pl. XIII, figs. 1-4.

Holotype. Pl. XIII, figs. 1-2; Sl 284 SM. Diameter $55 \mu$.

Type locality. Ørslev No. 1 borehole, D.G.U. file No. 238.502.

Type stratum. Marlstone, black-grey. Borehole depth $7743^{\prime} 0^{\prime \prime}$, Lower Viséan.

Derivation of name. Of membrana (lat.) = a thin skin and reticulum (lat.) = dim. of rete, a net.

Diagnosis. A Dictyotriletes species characterized by a fine, rather imperfect reticulum formed by $1-2 \mu$ high, membraneous muri. Lumina about 2-3 $\mu$ wide. Diameter 50-67 $\mu$. Amb convexly triangular with rounded apices. Suturae simple, straight, almost equal to spore radius. Exine $2-4 \mu$ thick.

Description. Miospores trilete, acavate. Diameter 50-67 $\mu$, mean $56 \mu$ (10 specimens). Amb convexly triangular with rounded apices. Suturae simple, straight, distinct, almost equal to spore radius. Exine ornamented with a rather imperfect reticulum. Muri $1-2 \mu$ high, basally $1 \mu$ wide, with membraneous edges. Mural junctions may be slightly thickened. Lumina about $2-3 \mu$ wide, polygonal to irregularly angular. Exine $2-4 \mu$ thick, rarely folded.

Discussion and comparison. This species is included in Dictyotriletes despite the small size of lumina and the irregular, imperfect reticulation. In Microreticulatisporites (KNOX) POTONIÉ and KREMP 1954 the lumina generally are subordinated to muri in width and are rounded. Dictyotriletes cheveriensis (PLAYFord 1963) comb. nov. has basically the same type of ornament, but differs from $D$. membranireticulatus by a more perfect and better developed reticulation and a different shape and size. Spore type 4 of Love $(1960$, p. 124; pl. 2, fig. 13 and text-fig. 15) has the same sculpture, but the size is larger and the suturae shorter than observed in D. membranireticulatus. 
Dictyotriletes cf. submarginatus PLAYFORD 1963

Pl. XIII, figs. 5-9; text-fig. 8.

Description. Miospores trilete, camerate. Diameter 55-74 $\mu$, mean $61 \mu$ (15 specimens). Amb convexly triangular with rounded apices. Suturae labrate, straight to sinuous, equal to radius of spore. Labra raised, 1-2 $\mu$ in width, 2-6 $\mu$ high (commonly $3 \mu$ ). Curvaturae concentric with the equator commonly marked by a fine line. Contact areas may be depressed (pl. XIII, fig. 7). Radius of contact areas about two thirds radius of spore. Proximal surface laevigate to scabrate. Distal surface ornamented with partly anastomosing muri forming an imperfect reticulum or with rugulae. Muri 2-5 $\mu$ wide, $2-4 \mu$ high, sinuous and rounded. Lumina irregular to polygonal, commonly $\frac{1}{2}-2$ times the width of muri in diameter. Exoexine (excl. sculpture) $2 \mu$ thick outside contact areas. Exoexine of contact areas thin (less than $2 \mu$ ). The difference in thickness of the exoexine gives rise to the observation of a darker equatorial ring on many specimens, when studied in transmitted light. Another characteristic feature of this species is the occurrence of basal mural narrowings, observable along the equator of the spore cavity as outwards directed tongue-shaped "cavities" (cf. pl. XIII, fig. 5 and text-fig. 8). Intexine thin, commonly detached in the equatorial region, not always visible.

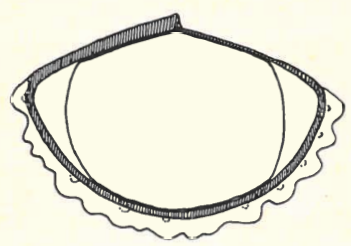

Text-fig. 8. Diagrammatic section of Dictyotriletes cf. submarginatus Playford 1963. $\times 500$.

Remarks. Specimens closely agree with D. submarginatus PlAYFORD 1963 in general appearance, although they are slightly more coarsely ornamented than most of the specimens figured. They apparently differ from the type material in being camerate. The basal mural narrowings are not confined to the equatorial region only and they are not comparable with the vacuoles of Vallatisporites. The stratigraphical range of $D$. submarginatus is Tournaisian to Viséan. (Playford 1963, Varma 1969, Kaiser 1970, Hibbert and Lacey 1969, Mortimer, Chaloner and Llewellyn 1970).

Dictyotriletes sp. (S1 224 SM)

Pl. XIV, fig. 4.

Description. Miospores trilete, acavate. Diameter 53-84 4 (4 specimens). Amb convexly triangular with rounded apices. Suturae simple, straight, partly 
covered by ornament, $0.4-0.8$ radius of spore. Exine ornamented with a regular reticulum. Muri parallel-sided in profile, flat-topped, $2-5 \mu$ in width, 2-3 $\mu$ high. Lumina rounded angular to narrowed irregular, equal to or less than the width of the surrounding muri in diameter. Exine 5-6 $\mu$ thick incl. sculpture.

Remarks. Several comparable spore types have been described and figured, e.g. Convolutispora sculptilis FeLIX and BURBrIDGe 1967, Dictyotriletes planus (Hughes and Playford 1961), "Reticulatisporites" type A of Love 1960. An identification to species has not been attempted.

\title{
Dictyotriletes sp. (SI 396 SM) \\ PI. XV, figs. 2-3.
}

Description. Miospores trilete, acavate. Diameter (excl. sculpture) 47-58 $\mu$ (3 specimens). Amb convexly triangular with rounded apices. Suturae simple, straight, distinct, $0.5-0.8$ radius of spore. Exine distally ornamented with a perfect, polygonal reticulum. Muri 1.5-2 $\mu$ high, and wide, semicircular in transverse section. Lumina about 5-10 $\mu$ in diameter. Reticulation disintegrates on the proximal surface into minor, individual but closely spaced rugulae and grana partly covering the suturae. Small grana $(0.5 \mu$ in diameter $)$ are spread on surface among the major elements. Exine $2 \mu$ ? thick.

\author{
Subturma Zonotriletes WALTZ 1935 \\ Infraturma Cingulati (Potonié and Klaus) Dettmann 1963 \\ Genus Stenozonotriletes (NAumova) PotoniÉ 1958 \\ Stenozonotriletes Sp. (SI 303 SM) \\ Pl. XVII, fig. 3.
}

Description. Miospores trilete, acavate. Diameter 38-57 (72?) $\mu$ (6 specimens). Amb convexly triangular with broadly rounded apices. Suturae simple, sinuous, indistinct, extending to spore body margin. Cingulum 5-8 $\mu$ wide. Exine infragranular to infravermiculate.

Remarks. Specimens are possibly identical with spores described as $S$. cf. stenozonalis (WALTZ 1938) by HACQUEBARD (1957) and JACHOWICZ (1967).

\section{Stenozonotriletes sp. (Sl 306 SM) \\ Pl. XVII, figs. 1-2.}

Description. Miospores trilete, acavate. Diameter 41-62 $\mu$, mean $48 \mu$ (20 specimens). Amb circular to broadly, convexly triangular with rounded apices. Suturae simple, straight, often indistinct, extending to spore body margin. Cingulum 3-4 $\mu$ wide. Exine infragranular.

4 D.G.U. II. rk. nr. 99 
Remarks. This form shows affinity to S. extensus var. major NAUmova 1953, as described by HACQUEBARD (1957).

\title{
Stenozonotriletes spp.
}

Remarks. Some unidentified and undescribed small specimens referable to Stenozonotriletes have been observed in the samples. Many species of this genus are unprecisely defined and of limited stratigraphical importance and a description of all recorded types is therefore omitted. Pl. XVII, figs. 5-6 shows a specimen belonging to this category.

\author{
Genus Murospora (Somers) Potonié 1966 \\ Murospora sublobata (WALtZ) PlAYFord 1962 \\ Pl. XVI, fig. 1.
}

1938 Zonotriletes sublobatus Waltz in Luber and WAltz, p. 17; pl. 2, fig. 22.

1957 Triquitrites tendoris HACQueBARD and BARss, p. 18; pl. 2, figs. 18-19.

1960 Murospora laevigata Staplin, p. 29; pl. 6, fig. 21.

1962 Murospora sublobata (WAltz) Playford, p. 613; pl. 86, figs. 17-19.

1967 Murospora sublobata (WALtz) PlAyford - JACHOwicz, p. 42; pl. 22, fig. 9.

Description. Miospores trilete, acavate. Diameter $42 \mu$ ( 2 specimens). Amb triangular with slightly convex to concave sides and rounded apices. Suturae simple, straight, distinct, almost extending to spore body margin. Spore body concavely triangular. Diameter $25-28 \mu$. Cingulum $6-9 \mu$ wide, apically increasing in width, with a few marginal incisions. Exine laevigate, thin.

Stratigraphical range. Tournaisian to Viséan.

Geographical distribution.

Europe: Poland (JACHOWICZ 1967).

U.S.S.R.: LUBER and WALTZ 1938.

Arctic region: Spitsbergen (PlAYFord 1962), Bear Island? (KAISER 1970).

North America: Canada (HacQuebard and BARss 1957, STAPLIN 1960).

\section{Murospora sp. (SI 298 SM)}

Pl. XVI, figs. 4-5.

Description. Miospore trilete, camrate.e Diameter $40 \mu$. Amb triangular with straight to slightly convex sides and rounded apices. Suturae finely labrate (membraneous labra), straight, distinct, almost extending to spore body margin. Spore body triangular, $27 \mu$ in diameter. Cingulum of uniform width, 3-4 $\mu$. A thin walled intexine is seen in the spore cavity. Exoexine laevigate, thin.

Remarks. This specimen is possibly referable to $M$. conduplicata (ANDREJEVA) PlAYFORD 1962 (p. 613, pl. 86, figs. 14-15). 


\section{Genus Knoxisporites (Potonié and Kremp) Neves 1961 \\ Knoxisporites hederatus (ISCHENKo) PLAYFORD 1963 \\ Pl. XVIII, fig. 1.}

1956 Euryzonotriletes hederatus IsCHENKo, p. 58; pl. 10, fig. 121.

1958 Euryzonotriletes hederatus IsCHENKo - Ischenko, p. 62; p1. 6, fig. 77.

1963a Knoxisporites hederatus (IsHCHENKo) PlAYFord, p. 634; pl. 90, figs. 9-12.

1964b Knoxisporites hederatus (IshCHENKo) Playford - Sullivan, p. 1253; pl. 2, figs. 1-2.

1967 Knoxisporites hederatus (IsCHENKO) PLAYFORD - JACHOWICZ, p. 51; pl. 29, figs. 1-2; pl. 30, fig. 4 .

1967 Knoxisporites hederatus (Ischenko) Playford - Felrx and Burbridge, p. 394; pl. 60 , figs. $4-5$.

Description. Miospores trilete, acavate. Diameter $65-91 \mu$ (12 specimens). Amb circular to subcircular. Suturae simple, straight, distinct, extending almost to cingulum. Cingulum irregular, 6-13 $\mu$ wide. Distal surface ornamented with (commonly three) broad, flat muri, interradially connected with cingulum, mutually united in an irregular pattern. Muri $2-12 \mu$ wide, commonly 7-8 $\mu$. Proximal surface sculptureless. Exine laevigate to finely infrapunctate, sometimes finely pitted by corrosion.

Remarks. In some cases this species is difficult to distinguish from K. pristinus Sullivan, described below. To the criteria of separation mentioned at page 52, may be added that $K$. hederatus is seldom deformed due to a stronger and thicker exine.

Stratigraphical range. Devonian to Namurian.

Geographical distribution.

Europe: England (Sullivan 1964b, Butterworth and SPInNer 1967, Dolby and Neves 1970, Johnson and Marshall 1971), Poland (JachoWICZ 1967).

U.S.S.R.: ISCHENKO 1956, 1958.

Arctic region: Spitsbergen (PlAYFORD 1963a).

North America: U.S.A. (Felix and Burbridge 1967), Canada (Barss 1967).

\section{Knoxisporites pristinus SullivaN 1968 \\ Pl. XVIII, figs. 3-6.}

1968 Knoxisporites pristinus Sullivan, p. 123; pl. 27, figs. 1-5.

1969 Knoxisporites pristinus Sullivan - HibBert and Lacey, p. 428; pl. 81, figs. 5, 6, 9.

Description. Miospores trilete, acavate. Diameter $62-81 \mu$, mean $70 \mu$ (11 specimens). Amb irregular, polygonally rounded. Suturae simple or with finey raised, membraneous labra, straight, distinct, extending almost to cingulum. Cingulum 4-7 $\mu$ (polar view), uniform. Distal surface ornamented with more 4* 
or less distinct muri, interradially connected with cingulum, commonly connected with a thickened distal ring or irregularly fused. Proximal surface sculptureless. The finely granular structure of the exine is seen in pl. XVIII, fig. 5 (scanning micrograph).

Remarks. K. rotatus Hoffmeister, Staplin and Malloy 1955 (p. 390; pl. 37, fig. 13) differs from $K$. pristinus in having a more regular, circular amb and proximal thickenings connecting the termini of suturae with the cingulum. K. hederatus (IsCHENKo 1956) and K. pristinus can not always be distinguished from each other on the basis of ornamentation, as they form the same type of irregular distal mural pattern. Specimens identified with $K$. pristinus are all characterized by a granular exine structure. But it must be emphasized, that the structure of the exine is not described by either Sullivan (1968) or Hibbert and LaceY (1969).

Stratigraphical range. Tournaisian to Viséan.

Geographical distribution.

Europe: Scotland (Sullivan 1968), England (Hibbert and Lacey 1969,

Llewellyn, BaCKhouse and Hoskin 1969, Johnson and Marshall 1971).

\section{Knoxisporites spp.}

Remarks. In addition to the two above described species of Knoxisporites, some rare forms referable to this genus were recorded. One specimen, pl. XVI, fig. 2, is identified with K. literatus (WALtz) Playford 1962; the others, pl. XVIII, fig. 2, pl. XIX, figs. 1-2, are unidentified. K. literatus has frequently been recorded from Lower Carboniferous deposits.

\section{Genus Reticulatisporites (IвRAHIM) Neves 1964 \\ Reticulatisporites copiosus n. sp. \\ Pl. XIX, fig. 6; pl. XX, figs. 2, 3, 5.}

Holotype. Pl. XX, fig. 2; Sl 334 SM. Diameter $130 \mu$.

Type locality. Ørslev No. 1 borehole, D.G.U. file No. 238.502.

Type stratum. Marlstone black-grey. Borehole depth 7739'4-9'. Lower Viséan.

Derivation of name. Of copia (lat.) = plenty.

Diagnosis. A Reticulatisporites species characterized by a wide $(20-25 \mu)$, peripherally thickened cingulum and a distal ornament, partly reticulate, of coarse (6-10 $\mu$ wide, 15-25 $\mu$ high), rounded muri connected with the cingulum. Diameter 96-154 $\mu$. Amb rounded polygonal. Border with incisions. Suturae labrate, extending to cingulum. Labra rounded, elevated muri, totally 15-20 $\mu$ wide. Spore body convexly triangular with rounded apices, 0.6-0.7 diameter of spore. Exine $1 \mu$ thick finely infrapunctate. 
Description. Miospores trilete, acavate. Diameter 96-154 $\mu$, mean $135 \mu$ (70 specimens). Amb rounded polygonal. Border with incisions. Suturae labrate, straight to slightly sinuous, distinct, extending to cingulum. Labra developed as a double row, 15-20 $\mu$ wide, of muri, semi-circular in transverse section and separated from each other (cf. pl. XX, fig. 3). Cingulum 20-25 $\mu$ wide, overlaps slightly onto the spore body, with a peripheral zone of thickening, sometimes incised. A variable number of muri, connected with the thickened zone of the cingulum, form a distal, irregular ornament pattern which is partly reticulate. Muri rounded, parallel-sided in transverse section, 6-10 $\mu$ wide, $15-25 \mu$ high. Proximal surface without ornamentation (except labra) or with a few rounded tubercula. Spore body convexly triangular with rounded apices, conform with outline of spore. Diameter of spore body $70-(88)-113 \mu=0.6-0.7$ diameter of spore. Exine $1 \mu$ thick, finely infrapunctate.

Discussion and comparison. This species is included in the genus Reticulatisporites (IBRAHIM) NEVES 1964 as the cingulum is differentiated in accordance to the emended diagnosis of Neves (1964). The cingulum of Cincturasporites HACQUEBARD and BARSS 1957 is simple and cuneiform in transverse section (cf. H. \& B. 1957, p. 21, fig. 2), as it is in Knoxisporites (РотоNiÉ and KremP) NEvES 1961, the latter having only minor overlap of the cingulum onto the spore body.

$R$. copiosus closely resembles $R$. intestinalis (HIBBERT and LACEY 1969, p. 429; pl. 81 , figs. $11-13$; pl. 82, figs. 1-3) comb. nov. $R$. intestinalis has a narrower cingulum and ornamented proximal surface, but has the same size range as $R$. copiosus. Cincturasporites magnus Felix and BURBridge 1967 (p. 399; pl. 61, fig. 4) also has the same size range, but has a simple cingulum which is even narrower. For comparison the size ranges and the widths of cingula of the three species are given below:
C. magnus Felix and Burbridge 1967
d. $90-125 \mu \quad$ cing. $8-12 \mu$
$R$. intestinalis (HIBBERT and LACEY 1969)
d. $92-143 \mu \quad$ cing. $10-19 \mu$
$R$. copiosus n. sp.
d. $96-154 \mu \quad$ cing. $20-25 \mu$

Genus Anulatisporites (LoOse) Potonié and Kremp 1954

Anulatisporites? sp. (SI 375 SM)

Pl. XIX, fig. 3.

Description. Miospores trilete, acavate. Diameter $97-118 \mu$ (4 specimens). Amb circular to convexly triangular with broadly rounded apices. Suturae simple, straight, distinct, 0.6 radius of spore body. Cingulum uniform in width on a single specimen, $13-25 \mu$ wide and differentiated in thickness in an equatorial darker zone and a thinner (and lighter) peripheral zone. Cingulum slightly overlaps the spore body. Spore body diameter 66-71 $\mu$. Proximal surface and cingulum without ornament. Distal surface shows different shadow- 
like pattern, which can be interpreted as original thickenings (muri) or secondary phenomena of compression. Exine (spore body wall) $2-3 \mu$ thick, infrapunctate.

Remarks. If specimens originally were unsculptured, they are closely comparable with Anulatisporites orbiculatus (WALTZ) PLAYFORD 1963 (p. 619; pl. 88, fig. 1), a species recorded from the Lower Carboniferous of the U.S.S.R. and Spitsbergen. As this question is unanswered, they are tentatively referred to Anulatisporites only, since this genus does not include ornamented forms.

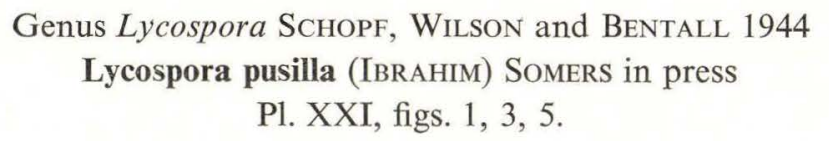

1932 Sporonites pusillus Ibrahim in Potonié, Ibrahim and Loose, p. 448; pl. 15, fig. 20.

A comprehensive list of synonyms is given by Somers.

Remarks. Specimens are frequently destroyed by corrosion and secondary growth of pyrite crystals. They conform closely with the diagnosis of Somers.

Stratigraphical range. Up. Tournaisian or L. Viséan to Stéphanian (? Autunian) (Somers in press).

Geographical distribution. According to SOMERS this species has a nearly world-wide geographical distribution. It has not been recorded from the Asiatic part of the Soviet Union.

\section{Lycospora? rugulosa BUTTERWORTH and SPINNER 1967 \\ Pl. XXI, fig. 2.}

\footnotetext{
? 1960 Cyclogranisporites tripapillatus STAPLIN, p. 9; pl. 1, fig. 29.

1967 Lycospora rugulosa BUtTerworth and SPINner, p. 10; pl. 2, figs. 1-2.

1970 Lycospora rugulosa BUtTERWORTH and SPINNER - MARShall and Williams, pl. 1, fig. 22.

1970 Cyclogranisporites tripapillatus STAPLIN - NeVEs and Williams, pl. 11, figs. 3-4.
}

Description. Miospores trilete, acavate. Diameter $26-41 \mu$, mean $35 \mu$ (48 specimens). Amb convexly triangular with rounded apices. Suturae simple or with very finely developed labra, straight, distinct, extending to spore body margin. Cingulum 2-3 $\mu$ wide with crenulate margin, undifferentiated in thickness (tapering). Distal surface bears rugulate ornament, proximal surface unsculptured except for three apical papillae, semiglobular, $2 \mu$ in diameter. Exine thin, infrapunctate, rarely folded.

Remarks. The mean size of the Danish specimens is higher than the mean size quoted by BUTTERWORTH (20-(29)-38 $\mu$ for 60 specimens), otherwise they are identical with the type material. The cingulum is not differentiated in an inner thickened zone and an outer thinner zone (zona) as it is in the genus 
Lycospora and therefore the species is only tentatively referred to this genus.

Stratigraphical range. Viséan.

Geographical distribution. Hitherto only? recorded from the Northumbrian Province of Great Britain (Butterworth and Spinner 1967, Marshall and Williams 1970, Neves and Williams 1970). The closely related, if not identical form C. tripapillatus STAPLIN 1960 was recorded from the Upper Mississippian Golata Formation of Canada.

\section{Genus Cristatisporites PotoniÉ and KREMP 1954}

Cristatisporites echinatus PLAYFORD 1963

Pl. IX, figs. 5, 8.

1963a Cristatisporites echinatus PlAYFORD, p. 637; pl. 91, figs. 1-4; text-fig. 10 f.

1963 Cristatisporites echinatus Playford - DetTMANn and Playford, p. 680; pl. 96, figs. 3-5.

1963b Cristatisporites echinatus PlAyford - Playford, p. 36; pl. 10, fig. 10.

Description. Miospores trilete, camerate. Diameter 67-76 $\mu$ (3 specimen). Amb convexly triangular, apices slightly pointed. Suturae labrate, extending almost to the equator. Labra raised, $5 \mu$ high and $2 \mu$ wide. Proximal surface laevigate. Distal surface evenly ornamented with rounded coni, $1-2 \mu$ high and $1-2 \mu$ in diameter, rather closely spaced, the distance apart being $0-3 \mu$. Cingulum (width non-measurable) distally ornamented. The proximal surface of cingulum shows radiating furrows corresponding to the intervals or incisions between the coni or the groups of fused coni along the equator (pl. IX, fig. 8). Exoexine infrapunctate. Intexine thin and folded.

Remarks. The ornament of the above described specimens corresponds to that of the specimen pl. 91, fig. 4 (PLAYFORD 1963a).

Stratigraphical range. Devonian? to Tournaisian.

Geographical distribution.

Europe: England (Utting and Neves 1970), France (Combaz and Streel 1970), Belgium-Germany (PAProth and Streel 1970).

Arctic region: Spitsbergen (PlAYFORD 1963a).

North America: Canada (Playford 1963b).

Infraturma Patinati Butterworth and Williams 1958

Genus Tholisporites ButTerworth and Williams 1958

Tholisporites decorus BharadWAJ and VenKatachala 1961

PI. XXI, figs. 4, 6.

1961 Tholisporites decorus Bharadwaj and Venkatachala, p. 39; p1. 10, figs. 142-146.

Description. Miospores trilete, camerate. Diameter 36-54 $\mu$, mean $45 \mu$ (28 specimens). Amb circular to convexly triangular with broadly rounded apices. 
Suturae simple, frequently split open, extending to the border of the intexine. Exoexine distally thickened, distinctly infrapunctate to minutely infravermiculate. Intexine very thin, more or less conforming with the equator, attached to exoexine in the polar regions.

Remarks. The patinate nature of specimens is indistinct.

Stratigraphical range. Tournaisian to Viséan.

Geographical distribution.

Europe: Scotland (GUEINN, pers. communication).

Arctic region: Spitsbergen (BharadwaJ and Venkatachala 1961).

\section{Tholisporites sp. (SI 388 SM)}

Pl. XX, figs. 1, 4.

Description. Miospores trilete, camerate. Diameter 53-80 $\mu$, mean $69 \mu$ (18 specimens). Amb irregularly subcircular to triangular with rounded apices. Suturae simple or with fine, raised labra, straight to sinuous, extending to the margin of the spore cavity. Exoexine strongly infrapunctate, distally and equatorially slightly thickened. Intexine thin, structureless, attached to exoexine in the proximal and equatorial region. Distally it may be independently folded. Spore cavity diameter more than two thirds diameter of spore.

Remarks. As in the former Tholisporites species it is not distinctly patinate.

Tholisporites sp. (SI 345 SM)

Pl. XIX, figs. 4-5; text-fig. 9.

Description. Miospores trilete, acavate. Diameter 70-79 Amb convexly triangular with broadly rounded apices. Suturae simple, straight, distinct, 0.6 radius of spore. Exine distinctly stratified. Intexine $1.5 \mu$ thick. Exoexine $3.5 \mu$ thick (unthickened part). Exoexine except over contact areas distinctally thickened. Patina up to $6 \mu$ thick along the equator, thinner distally, irregular in thickness. Contact areas irregularly defined, with indistinct low rugulate ornament.

Remarks. This species differs from T. scoticus Butterworth and Williams 1958 (p. 382; pl. 3, figs. 48-50) by its larger size and more well-defined exine stratification.

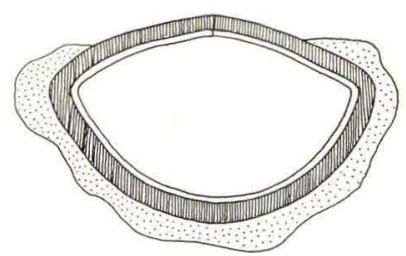

Text-fig. 9: Diagrammatic section of Tholisporites sp. (S1 345 SM), $\times 500$. 
Infraturma Zonati PotoniÉ and KREMP 1954

Genus Auroraspora Hoffmeister, Staplin and Malloy 1955

Auroraspora macra SULLIVAN 1968

Pl. XXIII, figs. 5-6.

1968 Auroraspora macra Sullivan, p. 124; pl. 27, figs. 6-10.

1971 Auroraspora macra Sullivan - Clayton, p. 580; pl. 1, fig. 3.

Description. Miospores trilete, monopseudosaccate. Diameter 50-70 $\mu$, mean $63 \mu$ ( 8 specimens). Amb circular to subcircular. Diameter of spore body (intexine) $34-51 \mu$, mean $41 \mu$. Outline of spore body circular to convexly triangular with broadly rounded apices. Suturae simple, straight distinct, $0.6-0.8$ radius of spore body. Exoexine membraneous, finely infrapunctate and pitted, with dark, shadowed areas along the peripheri (partial collapse?) and radiating minor folds. Intexine $1.5-2 \mu$ thick, laevigate to scabrate. Exoexine and intexine in proximal contact only.

Stratigraphical range. Tournaisian.

Geographical distribution.

Europe: Scotland (Sullivan 1968, Clayton 1971), England (Llewellyn, Backhouse and Hoskin 1969, Utting and Neves 1970, Johnson and MARSHALL 1971).

Auroraspora ef. solisortus HofFmeister, StAplin and MALloy 1955 Pl. XXIII, figs. 7-8.

Description. Miospores trilete, monopseudosaccate. Diameter 61-76 $\mu$, mean $67 \mu$ (10 specimens). Amb circular to subcircular. Diameter of spore body (intexine) $36-42 \mu$, mean $38 \mu$. Outline of spore body circular to convexly triangular with broadly rounded apices. Suturae simple or with fine, raised labra, straight, distinct, $0.6-0.8$ radius of spore body. Exoexine membraneous, infrapunctate and non-coloured. Minor radiating folds are common. Intexine $1.5-2 \mu$ thick, laevigate to scabrate. Exoexine and intexine in proximal contact only.

Remarks. This form is possibly identical with A. solisortus. However, the exoexine is described as being finely granular in the original description and in a later description by Felix and Burbridge (1967, p. 411), in contradiction to the infrapunctate structure seen in the Danish material. A. solisortus has a stratigraphical range from Tournaisian to Namurian. It has been recorded previously from U.S.A. and Great Britain.

The above described specimens resemble the spores identified with A. macra, but their thinner and colourless exoexine contrasts with the brown-shadowed one of the latter species. 


\section{Genus Aculeispores ARTÜz 1967 \\ Aculeispores Sp. (SI 261 SM) \\ Pl. XXIII, figs. 1-2.}

Description. Miospores trilete, monopseudosaccate. Diameter 49-62 $\mu$ (5 specimens). Amb subcircular to oval. Diameter of spore body (intexine) 35-40 $\mu$. Outline of spore body convexly triangular with rounded apices. Suturae labrate, straight, distinct, $0.7-0.8$ radius of spore body. Labra a few $\mu$ high, membraneous. Exoexine membraneous, infrapunctate, frequently folded. Unevenly spread grana and rounded coni, $1-2 \mu$ high make up a poor ornament. Intexine laevigate, $1.5-2.5 \mu$ thick. Exoexine and intexine in proximal contact only.

Remarks. The limited, conate sculpture of specimens is characteristic of Aculeispores. The exoexine of A. macra is laevigate, but corroded specimens of this species closely resemble $A$. sp. (S1 $261 \mathrm{SM}$ ).

\section{Aculeispores sp. (SI 259 SM) \\ Pl. XXIII, figs. 3-4.}

Description. Miospores trilete, monopseudosaccate. Diameter 58-67 $\mu$ (5 specimens). Amb circular to oval. Spore body (intexine) diameter 37-46 $\mu$. Outline of spore body circular to oval. Suturae labrate, straight to slightly sinuous, distinct, $0.5-0.8$ radius of spore body. Labra raised, $1 \mu$ wide, $1-2 \mu$ high. Exoexine membraneous, infrapunctate and ornamented with densely spaced bacula, $0.5-1 \mu$ in diameter, $2-3 \mu$ high, straight to crooked, terminally rounded or truncated. Distance apart of bacula frequently 0-2 $\mu$. Ornament reduced or absent on the proximal surface. Intexine laevigate, $1 \mu$ ? thick, only proximally attached to the exoexine.

Remarks. The above described specimens are referred to the genus Aculeispores on the basis of the baculate ornament. Rhabdosporites RICHARDSON 1960 has a baculate ornament, but the bacula are very small in proportion to the size of spore (micro-bacula).

\section{Genus Grandispora Hoffmeister, Staplin and Malloy 1955 Grandispora echinata HACQUEBARD 1957 Pl. XXII, figs. 1-2.}

1957 Grandispora echinata HaCQUeBARd, p. 317; pl. 3, fig. 17.

1963b Grandispora echinata HACQUEBARD - PlaYFord, p. 22; pl. 5, fig. 2.

1966 Grandispora echinata Hacquebard - Sullivan and Marshall, p. 280; pl. 4, figs. 1-3.

1966 Grandispora echinata HACQUeBARD - Neves and OWens, p. 350; pl. 3, fig. 6.

1968 Grandispora echinata HACQUeBARD - Sullivan, p. 126; pl. 27, figs. 11-13.

1968 Grandispora echinata HACQUEBARD - NEVILle, p. 447; pl. 2, fig. 8.

1969 Grandispora echinata HACQUEBARD - VARMA, p. 311; pl. 2, fig. 18.

? 1970 Grandispora echinata HACQUeBARD - KAISER, p. 111; pl. 24, figs. 1-2. 
Description. Miospores trilete, monopseudosaccate. Diameter 41-73 $\mu$, mean $58 \mu$ (27 specimens). Amb convexly triangular with rounded apices. Suturae labrate, straight to sinuous, distinct, extending almost to the equator. Labra raised, narrow, sinuous and tapering in height towards the apices. Max. height 4-6 $\mu$, width 1-2 $\mu$. Exoexine ornamented with spinae and coni, 1-2 $\mu$ high and $1-1.5 \mu$ in diameter, the distance apart of which is (commonly) $2-3 \mu$. Ornament mainly confined to distal surface. Exoexine less than $1 \mu$ thick, infrapunctate. Commonly it forms a "pseudo-limbus". Intexine conforms with outline of spore, is less than $1 \mu$ thick. Diameter of intexine about four fifths diameter of spore. Specimens frequently occur in tetrads.

Remarks. The variation of ornament described by Sullivan (1968) is also observed in the Danish material. The spores described from Canada generally seem to be larger than those recorded from Great Britain and Denmark. For comparison the following list is compiled:

Canada.

$$
\begin{array}{ll}
\text { HACQUEBARD 1957: } & \text { diam. } 62-93 \mu \text { (12 specimens) } \\
\text { PlayFORD 1963b: } & 59-(73)-96 \mu \text { (32 specimens) } \\
\text { VARMA 1969: } & 64-91 \mu \text { (15 specimens) }
\end{array}
$$

Europe.

$\begin{array}{ll}\text { SULLIVAN and MARSHALl 1966: } & 50-(64)-77 \mu \text { (13 specimens) } \\ \text { SulLIVAN 1968: } & 52-(62)-70(80) \mu \text { (42 specimens) } \\ \text { Present study: } & 41-(58)-73 \mu \text { (27 specimens) }\end{array}$

Sizes are not quoted by Neves and Owens (1966) and Neville (1968). The record of KAISER (1970) is debatable.

Stratigraphical range. Tournaisian to Namurian.

Geographical distribution.

Europe: Scotland (Sullivan and Marshall 1966, Sullivan 1968, Neville 1968), England (Neves and Owens 1966, Llewellyn, Backhouse and Hoskin 1969, Marshall and Williams 1970, Utting and Neves 1970, Johnson and Marshall 1971), Eire (Dolby 1970), Belgium-Germany (STREel 1970).

North America: Canada (Hacquebard 1957, Playford 1963b, Varma 1969).

Genus Spelaeotriletes Neves and Owens 1966

Spelaeotriletes cf. pretiosus (Playford) Neves and Belt 1970

Pl. XXII, fig. 5.

1971 Spelaeotriletes cf. pretiosus (Playford) Neves and Belt - Clayton, p. 590; pl. 3, figs. 7-8. 
Description. Miospores trilete, monopseudosaccate. Diameter 80-95 $\mu$ (5 specimens). Amb convexly triangular with rounded apices. Suturae labrate, straight to sinuous, extending almost to the equator. Labra raised, narrow, sinuous and sometimes terminally split, $1-2 \mu$ in width. Exoexine about $2 \mu$ thick, irregularly infragranular, ornamented with grana and rounded to pointed coni, $0.5-2 \mu$ high, $1-3 \mu$ in diameter. Ornamentation not very dense, proximally reduced. Intexine very thin, conforms with outline of spore. Diameter of intexine one half to two thirds diameter of spore. Spores folded and corroded.

Remarks. Specimens poorly preserved. The size range observed agrees with that quoted by Clayton (1971) for $S$. cf. pretiosus (59-(75)-101 $\mu$ ). The original size range of $S$. pretiosus is $98-(149)-195 \mu$ (PLAYford 1963b). The known stratigraphical range of $S$. pretiosus is restricted to the Tournaisian.

Gen. et sp. indet. (SI $295 \mathrm{SM}$ )

Pl. XXII, fig. 3.

Description. Miospore trilete, monopseudosaccate. Diameter $62 \mu$. Amb convexly triangular with rounded apices. Suturae labrate, slightly sinuous, distinct, extending to the equator. Labra raised, narrow, sinuous and tapering in height towards the equator. Max. height $5 \mu$. Exoexine evenly and densely verrucate. Verrucae very low, rounded in profile, with irregularly rounded bases, about $2 \mu$ in diameter, delimiting a fine, negative reticulum. Intexine thin and indistinct, conforms with outline of spore. Diameter of intexine two thirds diameter of spore. Exoexine and intexine in proximal contact only. Based on the folding and colour (light yellow) the thickness of the exoexine is estimated to be less than $1 \mu$.

Genus Discernisporites (Neves) NeVES and Owens 1966

Discernisporites cf. micromanifestus (Haquebard) Neves and Belt 1970 Pl. XXII, fig. 6.

Description. Miospores trilete, cavate. Diameter 55-74 $\mu$ (7 specimens). Amb convexly triangular with rounded apices. Suturae labrate, straight, distinct, extending almost to the equator. Labra raised, narrow, up to $4 \mu$ high. Exoexine distinctly infragranular, $1.5-2 \mu$ thick, rarely folded. Intexine thin and indistinct, conforms with outline of spore, not folded. Exoexine and intexine attached proximally and distally.

Remarks. Specimens differ from most of the spores referred to this species by the relatively larger diameter of the intexine, being about four fifths the diameter of spore. D. micromanifestus has a stratigraphical range from Devonian to Namurian (JOHNSON and Marshall 1971). 


\section{Genus Spinozonotriletes (HaCquebard) Neves and Owens 1966 \\ Spinozonotriletes sp. (SI 310 SM) \\ Pl. XXII, fig. 4.}

Description. Miospores trilete, cavate. Diameter $57-62 \mu$ (3 specimens). Amb convexly triangular with broadly rounded apices. Suturae simple, straight, indistinct, 0.6-0.8 radius of spore. Distal surface ornamented with thorn-like spinae and a few rounded coni, both types with rounded bases, $2-3 \mu$ in diameter. Spinae 3-4 $\mu$ high. About 20 spinae extend from the equator. Proximal surface unsculptured. Exoexine otherwise laevigate, thin (less than $1 \mu$ ?). Intexine finely infrapunctate, conforms with the outline of spore. Diameter of intexine about four fifths diameter of spore. Exoexine and intexine attached proximally and distally.

Remarks. The damaged specimen (pl. XXII, fig. 4) shows that the exoexine separates from the intexine only in the equator region, which is why specimens are referred to Spinozonotriletes rather than to Grandispora, in accordance with the emended diagnosis of the former genus by Neves and Owens (1966). Specimens show sculptural affinity to Grandispora spinosa HoffMEISTER, STAPLIN and MaLloy 1955, the originally described size of which is larger $(100-143 \mu)$.

Genus Perotrilites (Erdtman) Couper 1953

Perotrilites magnus Hughes and Playford 1961

Pl. XV, fig. 6.

1961 Perotrilites magnus Hughes and Playford, p. 33; pl. 2, figs. 5-6.

1962 Perotrilites magnus Hughes and Playford - Playford, p. 602; pl. 85, fig. 8.

1963b Perotrilites magnus Hughes and Playford - Playford, p. 32; pl. 9, fig. 5.

1969 Perotrilites magnus Hughes and Playford - HibBert and LACEY, p. 433; pl. 83, fig. 7 .

Description. Miospores trilete, camerate. Diameter (of intexine) 93-141 $\mu$ (4 specimens). Amb circular to oval. Suturae simple, straight, 0.6-0.7 radius of spore body. Exoexine thin, clear and structureless. It encloses the spore body in a distance from 4-10 $\mu$. Intexine (spore body wall) laevigate, $1.5-2 \mu$ thick, commonly folded.

Remarks. The membraneous exoexine ("perine") is frequently deformed by minor pyrite crystals. As the pyrite is removed in the preparation, the membrane sometimes has a secondary reticulate ornament formed by the impressions of crystals.

Stratigraphical range. Tournaisian to Viséan.

Geographical distribution.

Europe: Scotland (Sullivan 1968, Clayton 1971), England (Hibbert and LACEY 1969, Johnson and Marshall 1971).

Arctic region: Spitsbergen (Hughes and Playford 1961, Playford 1962).

North America: Canada (PlAyford 1963b). 
Perotrilites perinatus Hughes and Playford 1961

Pl. XV, figs. 4-5.

1961 Perotrilites perinatus Hughes and Playford, p. 33; pl. 2, figs. 7-10.

1962 Perotrilites perinatus Hughes and Playford - Playford, p. 602; pl. 85, figs. 6-7.

1963b Perotrilites perinatus Hughes and Playford - Playford, p. 33; pl. 10, fig. 5.

1966 Perotrilites perinatus Hughes and Playford - Sullrvan and Marshall, p. 282; pl. 4, fig. 4.

1967 Perotrilites perinatus Hughes and Playford - Butterworth and Spinner, p. 11; pl. 1, figs. 14, 17.

1967 Perotrilites perinatus Hughes and Playford - Felix and Burbridge, p. 379; pl. 57, figs. 14-15.

1969 Perotrilites perinatus Hughes and Playford - Varma, p. 310; pl. 2, figs. 16, 21.

1969 Perotrilites perinatus Hughes and Playford - HibBert and LACEY, p. 433; pl. 83, fig. 6 .

1970 Perotrilites perinatus Hughes and Playford - KaISer, p. 108; pl. 23, fig. 1.

Description. Miospores trilete, camerate. Diameter (of intexine) 46-66 $\mu$ (4 specimens). Amb convexly triangular with broadly rounded apices. Suturae simple, straight, distinct, 0.6-0.9 radius of spore. Exoexine membraneous, clear, structureless, normally folded or wrinkled and partly destroyed. Distance between exoexine and intexine commonly less than $10 \mu$. Intexine (spore body wall) laevigate, $1.5-3 \mu$ thick, rarely folded.

Stratigraphical range. Tournaisian to Namurian.

Geographical distribution.

Europe: Scotland (Sullivan and Marshall 1966, Clayton 1971), England (Butterworth and Spinner 1967, Hibbert and Lacey 1969, MarShall and Williams 1970, Utting and Neves 1970, Johnson and MarSHALL 1971).

Arctic region: Spitsbergen (Hughes and Playford 1961, Playford 1962), Bear Island (KAISER 1970).

North America: U.S.A. (Felix and Burbridge 1967), Canada (Playford 1963b, BARSS 1967, VARMA 1969).

Genus Rugospora Neves and Owens 1966

Rugospora corporata NEVES and OWENS var. verrucosa NEVILLE 1968 Pl. XVI, figs. 3, 6, 7 .

1966 Velamisporites rugosus BharadwaJ and Venkatachala - Sullivan and MarSHALL, p. 282; pl. 4, figs. 7, 9, 11.

1968 Rugospora corporata var. verrucosa Neville, p. 450; pl. 3, figs. 2-3.

? 1971 Rugospora cf. corporata Neves and OWens var. verrucosa Neville - Clayton, p. 587 ; pl. 3 , fig. 2 .

Description. Miospores trilete, camerate. Diameter 90-130 $\mu$ (7 specimens). Amb subcircular to oval, irregular. Spore body (intexine) diameter 80-111 $\mu$. 
Outline of spore body circular to oval. Suturae simple, straight, not always visible, 0.5-0.7 radius of spore body. Exoexine wrinkled and folded, scabrate, granular or micro-verrucate, thin. Intexine laevigate, $1-1.5 \mu$ thick, commonly with few major folds.

Stratigraphical range. Tournaisian to Viséan.

Geographical distribution. Hitherto only described from Great Britain.

Rugospora minuta NEVES and IOANNIDES in press

P1. XII, figs. 1-4.

? 1967 ? Secarisporites spp., Barss, pl. 6, figs. 20, 21, 22, 26, 27.

Description. Miospores trilete, camerate. Diameter 32-52 $\mu$, mean $44 \mu$ (46 specimens). Amb circular to convexly triangular with broadly rounded apices or (commonly) oval. Suturae simple, straight to slightly sinuous, indistinct, 0.6-0.8 radius of spore. Exoexine densely folded in a "brain-like" pattern. Folds $1.5-3 \mu$ wide, equatorially $3-8 \mu$ high. A radial pattern is commonly seen in the equatorial region, where some of the folds may extend as lobes. Folds generally smooth, but scanning micrograph may show the presence of minor grana at their flanks or in the incisions between the folds. Intexine is seen as a darker circular to oval body. Thickness of exoexine and intexine less than $1 \mu$.

Stratigraphical range. Tournaisian to Viséan. (NEvES, pers. communication).

Geographical distribution. Known from Canada? (BARss 1967) and Scotland (NEVES and IOANNIDES in press).

ALGAE INCERTAE SEDIS

Classis Hystrichophyta MÄDLER 1963

Ordo Tasmanales MÄDLER 1963

Familia Tasmanaceae SOMmer 1956

Genus Tasmanites Newton 1875

Tasmanites spp.

Remarks. Several specimens referable to this genus have been observed. Some of them are identified with T. sommeri WinsLow 1962 (p. 84) and T. huronensis (DAwSON) Winslow 1962 (p. 81). The figured specimen (pl. XXIV, fig. 1) may possibly be identified with T. sinuosus WinsLow 1962 (p. 83).

Ordo Leiosphaeridiales (EISENACK) MÄDLER 1963

Familia Leiosphaeridiaceae (EISENACK) MäDLER 1963

Genus Leiosphaeridia? EISENACK 1958

Remarks. Some globoid bodies (pl. XXIV, fig. 5) are tentatively referred to this genus, although they are rather thick walled. They have no visible pore channels and a pylome has not been observed. 


\section{DANSK SAMMENDRAG \\ EN NEDRE KARBON MIKROFLORA FRA BORINGEN \\ ØRSLEV NR. 1, FALSTER, DANMARK}

\section{INDLEDNING}

Lag af karbon alder blev for første gang med sikkerhed påvist i Danmark med boringen Ørslev nr. 1 (D.G.U. arkiv nr. 238.502). Boringens beliggenhed er vist på tekstfig. 1. Boringen, der blev udført af Dansk Undergrunds Konsortium (D.U.C.), nåede slutdybden $2573 \mathrm{~m}$ i januar 1968.

Under en serie evaporiter af øvre perm (zechstein) alder gennemboredes 229 m rødlige skifre, siltsten og sandsten, der kan henføres til øvre karbon eller nedre perm (rotliegendes). Herunder fulgte, fra dybden $2051 \mathrm{~m}$ til bunden af boringen $(2573 \mathrm{~m}$ ), vekslende lag af grå og sorte lersten og skifre, mergelsten og kalksten, gennemgående med en rig benthonisk fauna af brachiopoder, koraller, crinoider, foraminiferer og ostracoder.

Sidstnævnte lagserie er behandlet i to nyligt publicerede arbejder af CHRISTENSEN (1971) og MiCHELSEN (1971). ChristenSEN giver en lithologisk beskrivelse af de to kærneborede afsnit (2088-2103 m, kærne nr. 1 og 2343-2361 m, kærne nr. 2), samt en oversigt over fossilindholdet i kærnerne. Ved sammenligning med den karbone lagserie på Rügen, D.D.R., henfører han afsnittet over basis af kærne nr. 2 til viséen, medens den nederste del af lagserien muligvis bør henføres til tournaisien.

MiCHELSEN giver en sammenfattende beskrivelse af hele det nedre karbone profil. Gennem en detaljeret analyse af foraminiferfaunaen og sammenligning af denne med det nedre karbone typeområde i Belgien, er han i stand til at korrelere Ørslev lagserien med nedre viséen $\left(\mathrm{V}_{1}\right)$ og muligvis tillige (den øverste del af afsnittet) med mellem viséen $\left(\mathrm{V}_{2}\right)$.

Resultaterne af miospore analyser fra forskellige niveauer af karbonafsnittet behandles i dette arbejde. Som supplement bringes kortfattede beskrivelser af andre mikrofossiler af organisk materiale, scolecodonter, hystricosphaerider og alger? af Tasmanites type, da disses tilstedeværelse kan vise sig at være et værdifuldt bidrag til forståelsen af sedimentationsmiljøet.

Alle dybder er angivet $\mathrm{i}$ engelske fod (ukorrigerede prøvedybder) og meter (korrigerede dybder efter Schlumberger logs) under Kelly Bushing (KB). 


\section{MATERIALE OG METODER}

Tekstfig. 2 viser prøveniveauerne markeret på et lithologisk profil udarbejdet af MiCHELSEN (1971). Flertallet af prøverne er udtaget i kærne nr. 2, men ikke alle er anvendt, da det ved tællinger i bund, midte og top af kærnen blev klart, at sporeselskabet ikke ændrede sig nævneværdigt gennem denne. Endvidere er prøver fra intervallet mellem de to kærner blevet analyseret. Lokaliseringen i profilet af de undersøgte isolerede cuttings fra disse (skylle)prøver er baseret på Schlumberger logs. Prøver udtaget af kærne nr. 1 var golde med hensyn til sporer. Prøver fra afsnittet under kærne nr. 2 er ikke undersøgt, da cuttings i dette interval ikke kan lokaliseres med den fornødne præcision.

Da prøvematerialet var ret ensartet i lithologisk sammensætning (grå skifre, lersten og mergelsten) er den samme procedure fulgt ved hver tilberedning. Ca. $5 \mathrm{~g}$ prøve knuses mellem to lag plastfolie med en hammer og fraktionen under $1 \mathrm{~mm}$ overføres til et polyætylen bægerglas. Derpå opløses mesteparten af de forskellige uorganiske bestanddele i følgende bade: $20 \% \mathrm{HCl}$ i 24 timer, $40 \% \mathrm{HF}$, kogning i 1 time, 3 gange konc. $\mathrm{HCl}$, kogende, under omrystning, Schulzes opløsning (konc. $\mathrm{HNO}_{3}+\mathrm{KClO}_{3}$ ) i 3-5 min., $1 \% \mathrm{NH}_{4} \mathrm{Cl}$, idet der mellem hvert bad foretages en udvaskning i dest. vand (centrifugering). Efter en afsluttende vask på en rustfri stålsigte (maskevidde $14 \mu$ ) overføres sporekoncentratet via alkohol og benzol til opbevaring i silicone olie. Af hver centrifugerest er tilberedt mindst 3 flerkornspræparater. Dertil kommer adskillige hundrede enkeltkornspræparater.

En del sporer er undersøgt i scanning elektron mikroskop. Ved monteringen isoleres sporen fra en dråbe af centrifugeresten, der er smurt ud på et objektglas, med en fin »eethårspensel «. Efter vask i benzol i et urglas, kan sporen monteres på specimen-holder'en. Som klæbemiddel anvendtes »næsefedt « eller Araldit emulgeret i alkohol og påført knappen som en fin dughinde.

\section{STRATIGRAFISK UNDERSØGELSE}

\section{Mikrofloraens sammensæatning.}

Resultatet af tællingerne fremgår af tekstfig. 3. Selskabet i kærne nr. 2 er domineret af Tholisporites decorus BHARADWAJ \& VenKatachala og Rugospora minuta Neves \& IOANNIDes in press associerede med Schopfites claviger Sullivan, Anaplanisporites baccatus (Hoffmeister, Staplin \& Malloy) SMith \& Butterworth og Apiculiretusispora multiseta (Luber) Butterworth \& SPINNER, der er almindelige i alle prøver. De øvrige former er gennemgående sjældne. Bemærkelsesværdigt er forekomsten af Lycospora pusilla (IBRAHIM) SOMERS in press også i den nederste kærneprøve, da denne art spiller en afgørende rolle i den stratigrafiske analyse. De artsmæssigt rigeste og mest velbevarede selskaber er fundet nederst i kærnen. 
Selskabet fra skylleprøven $7270^{\prime}-80^{\prime}$ er karakteriseret ved en voldsom dominans af Lycospora? rugulosa BUtTerwORTH \& SPINNER, associeret med de førnævnte 5 arter.

I prøverne lige under kærne nr. 1, 6980'-90' og 6950'-60', genfindes selskaber, der omend artsfattige, i sammensætning minder stærkt om selskabet i kærne nr. 2, hvorfor forfatteren i den stratigrafiske analyse har valgt at behandle hele mikrofloraen som et sporeselskab, idet introductionen af $L$. ? rugulosa i skylleprøverne er det eneste kriterium for en opsplitning af mikrofloraen i to zoner. Den »afvigende « prøve, $7270^{\prime}-80^{\prime}$, indeholder ingen scolecodonter, men rigelige mængder af cuticula-stumper, hvorfor denne prøve antagelig repræsenterer en autochton, stærkt lokalpræget mikroflora, aflejret i et limnisk miljø.

De øvrige prøver indeholder scolecodonter og mikroalger, hvilket tyder på en sedimentation i littoralzonen, eftersom scolecodonterne tolkes som maxillae af polychæte orme, Errantida, der nutildags er karakteristiske i denne zone. Makrofossilerne, der hyppigt ses sammenskyllede i tynde lag, forekomsten af enkelte velbevarede plantefossiler (CHRISTENSEN 1971) og den benthoniske foraminiferfauna (MICHELSEN 1971) peger i samme retning. Sporeselskaber, der afsættes i dette milieu, vil derfor tilnærmelsesvist repræsentere gennemsnitsfloraen fra et større vegetationsområde, idet der foregår en vis opblanding under transporten og sedimenteringen. Fra et stratigrafisk synspunkt er et sådant sporeselskab langt mere værdifuldt end det lokale, stærkt facielt prægede selskab. Af samme grund er prøve $7270^{\prime}-80^{\prime}$ ikke behandlet særskilt i den stratigrafiske analyse.

Hovedparten af de former, der er henført til beskrevne arter, har vist sig at have en stratigrafisk udbredelse begrænset til nedre karbon. Til brug for en mere præcis korrelation er sporeselskabet blevet sammenlignet med mikrofloraerne fra naboregionerne indenfor det nordeuropæiske sedimentationsområde.

\section{Tidligere studier af nedre karbone mikrofloraer $i$ Nordvesteuropa.}

Tekstfig. 4 viser de lokalitetsområder i Nordvesteuropa, hvorfra nedre karbone miosporeselskaber er blevet beskrevet.

Miosporeselskaber fra devon/karbon overgangslagene er blevet detaljeret beskrevet fra Sydirland af Dolby (1970), fra det sydvestlige England af Sullivan (1964b), Neves \& Dolby (1967), Dolby (1970), Dolby \& Neves (1970) og Utting \& Neves (1970), fra det nordvestlige Frankrig af Combaz \& Streel (1970) og fra det Ardennisk-Rhinske bassin af Streel (1966, 1968, 1969, 1970) og Paproth \& Streel (1970). De beskrevne selskaber er alle ældre end mellem tournaisien $\left(\mathrm{Tn}_{2}\right)$ incl.

I de nævnte områder, som inkluderer typeområderne for de nedre karbone kronostratigrafiske enheder avonian, tournaisien og viséen og typelokaliteten for basis af karbon systemet (Hönnethal), overlejres de sporeførende overgangslag 
af mægtige kalkstensserier. Derved udelukkes muligheden for at etablere en palynologisk zonering af de yngre nedre karbone lagserier i disse områder. Kun én mikroflora af viséen alder er hidtil blevet publiseret fra området der indbefattes af de ovennævnte arbejder (SULLIVAN 1964a).

Heraf følger at kronostratigrafiske dateringer af yngre nedre karbone mikrofloraer fra andre områder, specielt disse fra non-marine aflejringer, ofte vil være en følge af en eller flere indirekte korrelationer, hvis værdi i mange tilfælde må betvivles.

Mægtige nedre karbone lagserier, ikke udviklede i Kohlenkalk facies (Carboniferous Limestone f.), er aflejrede i de northumbriske og skotske provinser (bassiner) i Storbritannien (jf. GEORGE 1969). Brakvandsaflejringer, deltaaflejringer og søaflejringer er hovedkomponenterne i disse bassiner. Marine horisonter er sparsomme, undtagen i de øverste aflejringer i begge bassiner og i den basale del af lagserien i den sydvestlige del af den northumbriske provins. I disse bassiner har etableringen af en koral-brachiopodzonering derfor vist sig vanskelig. På den anden side har man i denne region haft muligheden for at følge udviklingen og forandringerne af miosporeselskaberne gennem store dele af nedre karbon.

Miosporeselskaber er beskrevet fra adskillige lokaliteter i den skotske Midland Valley (Love 1960, Sullivan \& Marshall 1966, Sullivan 1968, Neville 1968, Clayton 1971 og Neves \& IoAnnides in press), hvoraf sidstnævnte forfatteres profil fra Spilmersford boringen, East Lothian, er det mest fuldkomne der hidtil er bearbejdet. Beskrivelser af mikrofloraer fra den northumbriske provins er givet af Butterworth \& Spinner (1967), Smith \& Butterworth (1967), Neves \& Williams (1970) og Marshall \& Williams (1971). Sammenlignet med den skotske provins er mikrofloraerne fra dette område mindre velkendte.

Miosporer er beskrevet fra den britiske centralprovins af HiBBERT \& LACEY (1969), Llewellyn, Backhouse \& Hoskin (1969), Mortimer, Chaloner \& Llewellyn (1970) og Johnson \& Marshall (1971). Selskabet beskrevet af HibberT \& LACEY er af viséen alder $\left(\mathrm{S}_{2}\right.$ eller $\left.\mathrm{D}_{1}\right)$, medens de øvrige antages at være af tournaisien alder.

Fra det nordeuropæiske fastland er der kun publiceret få palynologiske beskrivelser af nedre karbone aflejringer, hvis man ser bort fra det ArdenniskRhinske bassin. Doubinger \& RAuscher (1966) har beskrevet en mikroflora af øvre viséen alder, fra Vogeserne i Østfrankrig. Lagserien var tidligere dateret på basis af brachiopoder.

KALiBOva (1971) har beskrevet en nedre karbon mikroflora fra boringen Tb-1 i Bøhmen, Tjekkoslovakiet, medens en omfattende beskrivelse af mikrofloraerne fra Zaręby lagserien i Swieto Krzyz bjergene (Hellig Kors bjergene), Sydøstpolen er givet af JACHOWICZ (1967 og 1970). Disse lag blev oprindeligt dateret til tournaisien af ZAKOWA (1962). Øvre viséen selskaber er også publiceret af JACHOwICZ (1970) o.a. fra forskellige egne af det sydlige Polen. De nedre 
karbone mikrofloraer fra Rügen er, ifølge KNÜPFER \& WEYER (1967) under bearbejdelse.

Det turde fremgå af den foranstående diskussion, at ækvivalenter til Ørslev miosporeselskabet, der indirekte ved hjælp af foraminiferer kan dateres til at have en nedre viséen alder, muligvis er tilstede i den skotske provins, da dette område sandsynligvis er det eneste i Nordvesteuropa, hvor sammensætningen og udviklingen af mikrofloraen kan følges kontinuerligt gennem den største del af nedre karbon. En direkte korrelation til Belgien er udelukket, siden det i dette område kun er muligt at følge udviklingen af mikrofloraen gennem den ældste del af nedre karbon, på grund af tilstedeværelsen af en kalkstensfacies i de yngre lagserier. De yngste bevarede selskaber findes i Belgien således i $\mathrm{Tn}_{2}$ underetagen.

Korrelation med Skotland og det nordlige England.

Ørslev selskabet er direkte sammenligneligt med selskaberne i Lycospora pusilla $(\mathrm{Pu})$ zonen beskrevet fra Spilmersford boringen i East Lothian, Skotland af Neves \& IoAnnides in press. Zonen adskilles fra den underliggende Schopfites claviger-Auroraspora macra (CM) zone ved den første forekomst af $L$. pusilla (Ibrahim) SOmers in press, en art der er tilstede i Ørslev selskabet, omend i ringe mængde. Zonen er karakteriseret ved tilstedeværelsen af L. pusilla associeret med adskillige arter der også er fundet i Ørslev selskabet: Verrucosisporites nitidus (Naumova) Playford, Schopfites claviger Sullivan, Baculatisporites fusticulus Sullivan, Raistrickia corynoges Sullivan, Knoxisporites literatus (Waltz) Playford og Auroraspora macra Sullivan.

Tholisporites decorus Bharadwaj \& Venkatachala, Dictyotriletes cancellatus (Waltz) PotoniÉ \& Kremp og Anaplanisporites baccatus (HoffMeister, Staplin \& Malloy) SMith \& Butterworth, af hvilke den først- og sidstnævnte art er almindelige i Ørslev selskabet forekommer også i denne zone, samt i zonerne umiddelbart over og under i Spilmersford boringen.

Vallatisporites ciliaris (LUBER) SULlIVAN og Knoxisporites stephanorus Love er arter, der markerer overgangen til den overliggende Perotrilites tessellatusSchulzospora campyloptera (TC) zone (Neves, Gueinn, Clayton, IoAnNides \& Neville in press). Ingen af disse former eller andre, der optræder for første gang i TC zonen er fundet i de undersøgte prøver. Forekomsten af Lycospora? rugulosa BUtTERWORTH \& SPINNER i skylleprøverne fra den øvre del af det undersøgte interval, indicerer at selskaberne i disse prøver bør korreleres med den mellemste del af $\mathrm{Pu}$ zonen, siden den ældste forekomst af denne art synes at være i Cambeck Beds, Nordvestengland (Butterworth \& Spinner 1967), hvor den forekommer associeret med arter fra den øverste del af $\mathrm{Pu}$ zonen (V. ciliaris). Cambeck Beds $\left(\mathrm{C}_{2}\right.$ alder) er korreleret med nedre viséen (DAY 1970).

Da resultaterne af NEVES \& IOANNIDES undersøgelser i Spilmersford boringen 
endnu ikke er publicerede, er det ikke muligt at bringe en detaljeret sammenligning mellem selskaberne herfra og fra Ørslev. Clayton's selskab fra Cockburnspath området i Sydøstskotland synes at være noget ældre end selskabet i kærne nr. 2. Bortset fra mangelen af Lycospora spp., former der ifølge ClaYTON (1971, p. 597) forekommer kun $30 \mathrm{ft}$ over den yngste prøve beskrevet fra Birnieknowes boringen, er selskaberne meget ens. Clayton's artsliste er gengivet i tekstfig. 5 .

Selskaberne beskrevet af BUTTERworth \& SPINNER (1967) (jf. tekstfig. 5) fra the Cambeck Beds $\left(C_{2}\right)$ og de ældre Bewcastle Beds $\left(C_{1}\right.$, jf. DAY 1970) fra Nordvestengland er korreleret med den øverste del af $\mathrm{Pu}$ zonen baseret på forekomsten af $V$. ciliaris (Neves, Gueinn, Clayton, Ioannides \& Neville in press). Disse selskaber er ret artsfattige og kan bedst sammenlignes med selskabet i skylleprøven $7270^{\prime}-80^{\prime}$. De har ikke den samme udtalte lighed med selskabet i kærne nr. 2, som selskabet fra Cockburnspath. De er imidlertid de eneste $\mathrm{Pu}$ zone selskaber der indtil nu er publicerede fra de to nordlige provinser.

$\mathrm{Pu}$ zonen antages at være mere eller mindre ækvivalent med koral-brachiopod zone $C_{1}$ (Neves, Gueinn, Clayton, Ioannides and Neville in press). Nye undersøgelser af foraminiferfaunaerne i sydvest provinsen (GEORGE 1969) af England har medført at the Caninia Oolite bør korreleres med nedre viséen i Belgien $\left(V_{1 a}\right.$ eller muligvis $V_{1 b}$ ) jf. Conil \& George (1971). Den øvre del af the Lower Caninia Zone $\left(\mathrm{C}_{1}\right)$ inkluderende the Caninia Oolite kan derfor jævnføres med nedre viséen i Belgien og ikke som tidligere antaget med øvre tournaisien. Aflejringer karakteriseret af Pu zone selskaber kan derfor indirekte korreleres med det belgiske øvre tournaisien-nedre viséen.

Korrelation med nedre karbone mikrofloraer udenfor Nordvesteuropa.

U.S.S.R.

En sammenligning er foretaget med sporeselskaberne beskrevet af KEDO (1963, 1966) fra Pripet sænken, et område nordvest for Kiev, Hvide Rusland. Ørslev selskabet kan antagelig bedst sammenlignes med selskaberne fra Bobrikov 2 »komplekset «.

Dette er karakteriseret ved den første optræden af L. pusilla. Apiculiretusispora multiseta (LUBER) BUtTerworth \& SPINNER og Acanthotriletes dominans $\mathrm{KEDO}=$ ? Acanthotriletes spinosus (NAUmova) Ischenko, begge almindelige $\mathrm{i}$ Ørslev selskabet, er karakteristiske komponenter af både Bobrikov 1 og Bobrikov 2 selskaberne (jf. KeDo 1966, p. XII).

Skønt Pripet sænken må antages at have været beliggende på nogenlunde samme palæobredde som Ørslev og the Midland Valley (Scotland), har selskaberne herfra ikke megen lighed med selskaberne fra de sidstnævnte områder. Bobrikov horisonten er af PAPROTH (1969, p. 289, table VII) blevet jævnført med det belgiske viséen $\left(\mathrm{V}_{1 \mathrm{~b}}\right)$ og med $\mathrm{C}_{1}^{\mathrm{v}} \mathrm{d}$ i Donetz bassinet. 
Sammenligningerne med Donetz bassinet er baseret på udbredelsestabellerne udarbejdet af IscheNko (1956). Kun få af arterne i Donetz selskaberne genfindes i Ørslev.

Convolutispora amplecta f. kasachstanensis (LUBER) JACHOwICZ, Dictyotriletes cancellatus, Knoxisporites hederatus (IsCHENKo) Playford og Knoxisporites literatus har en vertikal udbredelse omfattende $\mathrm{C}_{1}^{\mathrm{t}}$ og $\mathrm{C}_{1}^{\mathrm{v}} \mathrm{a}-\mathrm{e}$. Punctatisporites platirugosus (Waltz) Sullivan var. minutus Waltz, Punctatisporites glaber (Naumova) Playford, A. spinosus og L. pusilla forekommer ikke i lag ældre end $\mathrm{C}_{1}^{\mathrm{v}} \mathrm{a}$. Leiotriletes ornatus IsCHENKo er begrænset til aflejringer yngre end $\mathrm{C}_{1}^{\mathrm{v} f}$. Lophotriletes aff. grumosus NAUmOVA $=$ ? Verrucosisporites nitidus (NAUMOVA) PLAYFord er ikke fundet $i$ lag yngre end $C_{1}^{t} d$.

På basis af disse arters udbredelse kan Ørslev selskabet korreleres med $\mathrm{C}_{1}^{\mathrm{v}} \mathrm{a}-\mathrm{e}$ intervallet i Donetz bassinet. Dette modsvarer omtrentligt nedre viséen i Belgien, da den overliggende subzone $\mathrm{C}_{1}^{\mathrm{v}} \mathrm{f}_{1}$ med nogen sikkerhed kan korreleres med $V_{2 b}$ i Belgien og $C_{1}^{t} c$ kan korreleres med $T_{2 b-2 c}$ (AISENVERG, BrazhniKOVA \& VDOVENKo 1971). Intervallet mellem disse to horisonter er vanskeligt at korrelere med Belgien p. gr. af forskellig faciel udvikling i de to områder.

Adskillige af arterne anvendt $\mathrm{i}$ den ovenstående korrelation har vist sig at have en større vertikal udbredelse i Donetz bassinet end anført ovenfor (ISCHENKo 1958). Dette ændrer dog ikke den generelle korrelation.

\section{Canada.}

Et sporeselskab afbildet af BARss (1967, pl. 5-6) har mange lighedspunkter med Ørslev selskabet. Bemærkelsesværdigt er de mange illustrationer af cavate eller »perinate « sporer. Former anført som Secarisporites? spp. er muligvis identiske med Rugospora minuta Neves \& IOANNIDEs in press, en dominerende art i Ørslev selskabet.

Dette selskab stammer fra en horisont i den østcanadiske Windsor Group og dets alder anføres som viséen af BARSs. Det præcise niveau i gruppen er ukendt og den generelle korrelation mellem Windsor gruppen og den europæiske standard zonering er endnu uafklaret. PLAYFORD (1963b) nævner at den nederste del af Windsor gruppen, på basis af en marin fauna, må være af ældre viséen alder. Neves \& Belt (1970) mener at gruppen er af mellem til yngre viséen alder. Selskabet afbildet af BARss er forskelligt fra selskaberne beskrevet fra den øverste del af the Windsor Group af Neves \& BeLt, der er sammenlignelige med selskaber af yngre viséen alder i Skotland. Alderen af selskabet afbildet af BARSS er derfor muligvis ældre eller mellem viséen.

Sporeselskaber fra den underliggende Horton Group er beskrevet af HACQUEBard (1957), Playford (1963b) og Varma (1969). Mikrofloraen i den øverste formation i gruppen, Cheverie formationen, er sammenlignelig med Schopfites claviger-Auroraspore macra (CM) zonen i Skotland og flere af arterne fra Ørslev forekommer i disse lag. De ældre selskaber fra the Undifferentiated 
Horton Group kan sammenlignes med selskaberne beskrevet fra the Lower Limestone Shales of Burrington Combe (Dolby \& Neves 1970) og Forest of Dean (Sullivan 1964b), idet de har flere diagnostiske arter tilfælles.

De nedre karbone miosporeselskaber fra Nordvestcanada, beskrevet af Hacquebard \& Barss (1957) og Playford \& Barss (1963), blev af Sullivan (1965) henregnet til Monilospora »suiten «, repræsentativ for en nordlig floraprovins, sammen med selskaberne beskrevet fra Spitsbergen af HugHeS \& Playford (1961), Bharadwaj \& Venkatachala (1961) og Playford (19621963a). En sammenligning med disse selskaber er ikke foretaget i dette arbejde.

\section{Konklusioner.}

Miosporeselskabet fra Ørslev boringen er sammenligneligt med selskaber beskrevet fra det østlige Canada (nedre del af the Windsor Group og den underliggende Cheverie Formation i the Horton Group), Skotland ( $\mathrm{Pu}$ zonen i the Calciferous Sandstone Measures), det nordlige England (Bewcastle Beds og Cambeck Beds) og Sovjetunionen (Bobrikov 2 horisonten i Pripet sænken, Hvide Rusland, samt $\mathrm{C}_{1}^{\mathrm{v}}$ etagen i Donetz bassinet).

Der er størst overensstemmelse med selskaberne fra Skotland, Nordengland og Canada. Dette tolkes som en følge af en datidig mere samlet beliggenhed af områderne. Det synes samtidig at vise, at det sporeproducerende plantesamfund, der eksisterede langs sydranden af det tidligere »Old Red kontinent «, var ensartet over større afstande. Palæomagnetiske målinger og facies udviklingen (revdannelser etc.) viser at klimaet må have være tropisk. Det semi-aride miljø, der antages at have været forudsætningen for dannelsen af den såkaldte »Cementstone facies « i Canada og Skotland (Belt et al. 1967, Neves \& BeLT 1970), har antagelig også eksisteret inden for det danske område.

Selskaberne, som er anført som sammenlignelige med selskabet fra Ørslev boringen, er alle indirekte blevet henført til øvre tournaisien eller nedre viséen, som defineret i Belgien. Ørslev selskabet lader sig derved indirekte korrelere med det belgiske typeområde på en måde, der understøtter Michelsen's konklusioner, idet han jævnførte det nedre karbone afsnit i boringen til nedre og mellem? viséen og CHRISTENSEN, der henførte afsnittet til tournaisien? og viséen. 


\section{ACK NOWLEDGMENTS}

The author wishes to express his gratitude to Dr. L. BANKe RAsmussen, head of the Department of Subsurface Geology, for suggesting the project and for making available the material.

In particular the author would like to thank Dr. R. NEves and his colleagues, Dr. K. J. Gueinn and Dr. G. Clayton, for many valuable discussions, practical help and for permitting study of the collections of the Department of Geology, University of Sheffield, Great Britain; Dr. M. Streel of the University of Liège, Belgium for valuable information about the Belgian type area and for the loan of some Russian literature; Dr. Y. Somers of InIEx, Liège for courteously permitting the use of an unpublished manuscript.

The visit to Sheffield was financed by the RASK-ØRSTED Foundation, which is gratefully acknowledged.

The scanning electron micrographs were taken at the Institute of Historical Geology and Palaeontology, University of Copenhagen by Mrs. A. NørGÅRD Jensen and Mr. J. Fuglsang and at the Geological Survey of Denmark by Mr. Sato and Mr. Suzuki, engineers of the Jeol Company, who kindly assisted the author. Mr. O. NEERGÅRd RAsmussen (D.G.U.) has done the photographic dark room work. The author is indebted to Dr. K. J. GueInN, University of Sheffield, who has corrected my English. Miss A. Demina, Geological Survey of Greenland, has kindly translated the abstract to Russian.

Geological Survey of Denmark

Thoravej 31

DK-2400 København NV

Denmark

March, 1972. 


\section{REFERENCES}

Aisenverg, D. E., Brazhnikova, N. E. and Vdovenko, M. V., 1971. An essay to the Correlation of the Tournaisian and Lower Viséan of the Donets Basin and Belgian Stratotype. - Résumé in Zusammenfassungen der Vorträge und Veröffentlichungen, 7. Int. Kongr. Strat. Geol. Karb., pp. 5-7, Krefeld 1971. - Krefeld.

Andersen, S. T., 1960. Silicone Oil as a Mounting Medium for Pollen Grains. - Danm. Geol. Unders., IV rk., 4, 1, 24 pp. - København.

Barss, M. S., 1967. Carboniferous and Permian Spores of Canada. - Geol. Surv. Canada Paper 67-11, 94 pp. - Ottawa.

Belt, E. S., Freshney, E. C. and Read, W. A., 1967. Sedimentology of Carboniferous Cementstone Facies, British Isles and Eastern Canada. - J. Geol., 75, 6, pp. 711-721. Chicago.

Bharadwaj, D. C. and Venkatachala, B. S., 1961. Spore Assemblage out of a Lower Carboniferous Shale from Spitzbergen. - Palaeobotanist, 10, 1-2, pp. 18-47. - Lucknow.

Butterworth, M. A. and Spinner, E., 1967. Lower Carboniferous spores from Northwest England. - Palaeont., 10, 1, pp. 1-24. - London.

Butterworth, M. A. and Williams, R. W., 1958. The Small Floras of Coals in the Limestone Coal Group and Upper Limestone Group of the Lower Carboniferous of Scotland. - Trans. R. Soc. Edinb., 63, 2, pp. 353-392. - Edinburgh.

Christensen, O. B., 1971. Nedre karbon i dybdeboringen Ørslev nr. 1 på Falster. - Danm. Geol. Unders., Rapp. nr. 7, 24 pp. - København.

Clayton, G., 1971. A Lower Carboniferous miospore assemblage from the Calciferous Sandstone Measures of the Cockburnspath Region of Eastern Scotland. - Pollen Spores, 12, 4, pp. 577-600. - Paris.

Combaz, A. and Streel, M., 1970. Microfossiles végétaux du Tournaisien inférieur dans le "core-drill" de Brévillers (Pas-de-Calais, France). - Congr. Coll. l'Univ. Liège, 55, pp. 227-240. - Liège.

Conil, R. and George, T. N., 1971. The age of the Avonian Caninia Oolite in Gower. Résumé in Zusammenfassungen der Vorträge und Veröffentlichungen, 7. Int. Kongr. Strat. Geol. Karb., Krefeld 1971, pp. 37-38. - Krefeld.

DAY, I. B. W., 1970. Geology of the Country around Bewcastle. - Mem. geol. Surv. GtBr. London.

Dettmann, M. E. and Playford, G., 1963. Sections of some spores from the Lower Carboniferous of Spitsbergen. - Palaeont., 5, 4, pp. 679-681. - London.

Dolby, G., 1970. Spore Assemblages from the Devonian/Carboniferous Transition Measures in South-West Britain and Southern Eire. - Congr. Coll. l'Univ. Liège, 55, pp. 267-274. - Liège.

- and Neves, R., 1970. Palynological evidence concerning the Devonian-Carboniferous boundary in the Mendips, England. - C. R. 6e Congr. Intern. Strat. Géol. Carbonif., Sheffield 1967., 2, pp. 631-646. - Maastricht.

Doubinger, J. and Rauscher, R., 1966. Spores du Viséen marin de Bourbach-Le-Haut dans les Vosges du Sud. - Pollen Spores, 8, 2, pp. 361-405. - Paris.

Downie, C. and Sarjeant, W. A. S., 1963. On the interpretation and status of some Hystrichosphere genera. - Palaeont., 6, pp. 83-96. - London.

EisenaCK, A., 1955. Chitinozoen, Hystrichosphären und andere Mikrofossilien aus dem Beyrichia-Kalk. - Senckenberg. leth., 36, pp. 157-188. - Frankfurt a. M.

Felix, C. J. and Burbridge, P. P., 1967. Palynology of the Springer Formation of Southern Oklahoma, U.S.A. - Palaeont., 10, 3, - pp. 349-425. - London.

George, T. N., 1969. British Dinantian Stratigraphy. - C.R. 6e Congr. Int. Strat. Geol. Carbonif., Sheffield 1967, 1, pp. 193-218. - Maastricht.

Grebe, H., 1971. A recommended terminology and descriptive method for spores. - 
Publ. C.I.M.P., 4 (Spores), 11-34. - Paris.

Ha Cquebard, P. A., 1957. Plant Spores in coal from the Horton Group (Mississippian) of Nova Scotia. - Micropaleont., 3, 4, pp. 301-324. - New York.

- and BARss, M. S., 1957. A Carboniferous spore assemblage in coal from the South Nahanni River area, North-west Territories. - Geol. Surv. Canada Bull., 40, 63 pp. Ottawa.

Hibbert, F. A. and Lacey, W. S., 1969. Miospores from the Lower Carboniferous Basement Beds in the Menai Straits region of Caernarvonshire, North Wales. - Palaeont., 12, 3, pp. 420-440. - London.

Hoffmeister, W. S., Staplin, F. L. and Malloy, R. E., 1955. Mississippian Plant Spores from the Hardingsburgh Formation of Illinois and Kentucky. - J. Palaeont., 29, 3, pp. 372-299. - Tulsa.

Hughes, N. F. and PlAyford, G., 1961. Palynological reconnaissance of the Lower Carboniferous of Spitsbergen - Micropaleont., 7, 1, pp. 27-44. - New York.

Ischenko, A. M., 1956. (Spores and Pollen in Lower Carboniferous Coal Deposits of the Western Extension of the Donetz Basin and their stratigraphic Significance). - Akad. Nauk. Ukrain. S.S.R. Inst. Geol. Nauk. Trudy, Ser. Strat. Pal., 11, 184 pp. (in Russian). - Kiev.

- 1958. (Spore and Pollen Analysis of Lower Carboniferous Sediments of the DnieperDonetz Basin). - Ibidem, 17, 188 pp. - Kiev.

JACHowicz, A., 1967. (Microflora of the Zaręby Beds from the Świetokrzyskie Mountains). - Inst. Geol. Prace, 49, 105 pp. (in Polish w/English Résumé.) - Warszawa.

- 1970. Tournaisian and Upper Viséan microfloras of the Swiety Krzyz Mountains (Central Poland), their stratigraphical and palaeogeographical value. - C. R. 6e Congr. Int. Strat. Geol. Carbonif., Sheffield 1967, 3, pp. 983-1008. - Maastricht.

Johnson, G. A. I. and Marshall, A. E., 1971. Tournaisian Beds in Ravenstonedale, Westmorland. - Proc. Yorks. geol. Soc., 38, 2, pp. 261-280. - Leeds.

KaISER, H., 1970. Die Oberdevon-Flora der Bäreninsel. 3. Mikroflora des Höheren Oberdevons und des Unterkarbons. - Palaeontographica B, 129, pp. 72-124. - Stuttgart.

Kalibova, M., 1971. Miospores of the turma Triletes (Reinsch) Potonié and Kremp 1954 in Lower Carboniferous in Eastern Bohemia. - Čas. min. geol., 16, 1, pp. 47-66. Praha.

Kedo, G. I., 1963. (Spores of the Tournaisian Stage of the Pripyat Depression and their stratigraphical significance). - Akad. Nauk. B.S.S.R. Inst. Geol. Nauk. Palaeont. Strat., 4, pp. 3-143 (in Russian). - Minsk.

- 1966. (Lower Carboniferous Spores of the Pripyat Depression). - Ibidem, 5, pp. 3-143 (in Russian) - Minsk.

KNÜPfER, J. and WeYER, D., 1967. Vorläufige Mitteilung über das Unterkarbon der Insel Rügen. - Ber. deutsch. Ges. geol. Wiss., A. Geol. Paläont., 12, 3/4, pp. 185-192. Berlin.

Kosanke, R. M., 1950. Pennsylvanian spores of Illinois and their use in correlation. - Bull. Ill. State geol. surv., 74, 128 pp. - Urbana, Illinois.

Llewellyn, P. G., Backhouse, J. and Hoskin, I. R., 1969. Lower-Middle Tournaisian miospores from the Hathern Anhydrite Series, Carboniferous Limestone, Leicestershire. - Proc. geol. Soc. Lond. 1655, pp. 85-91. - London.

Love, L. G., 1960. Assemblages of Small Spores from the Lower Oil-Shale Group of Scotland. - Proc. R. Soc. Edin. Section B, 67, pp. 99-126. - Edinburgh.

Luber, A. A. and WAltz, I. E., 1938. (Classification and stratigraphic value of spores of some Carboniferous coal deposits of the U.S.S.R.) - Trans. Central. Geol. Prosp. Inst., 105, 45 pp. (in Russian w/English Résumé). - Moscow.

MÄDLER, K., 1963. Die figurierten organischen Bestandteile der Posidonienschiefer. Beih. geol. Jb., 58, pp. 287-406. - Hannover. 
- 1967. Hystrichophyta and acritarcs. - Rev. Palaeobotan. Palynol., 5, pp. 285-290. Amsterdam.

Marshall, A. E. and Williams, J. E., 1970. Palynology of the Yoredale "Series" in the Roman Wall district, northern England. - C.R. 6e Congr. Int. Strat. Geol. Carbonif., Sheffield, 3, pp. 1147-1158. - Maastricht.

Michelsen, O., 1971. Lower Carboniferous Foraminiferal Faunas of the Boring Ørslev No. 1, Island of Falster, Denmark. - Danm. Geol. Unders., 2 rk., 98, 86 pp. - København.

Mortimer, M. G., Chaloner, W. G. and Llewellyn, P. G., 1970. Lower Carboniferous (Tournaisian) Miospores and Megaspores from Breedon Cloud Quarry, Leicestershire. Mercian Geol., 3, 4, pp. 375-386. - Nottingham.

Naumova, S. N., 1953. (Sporo-pollen complexes of the Upper Devonian of the Russian Platform and their stratigraphical value). - Tr. Inst. Geol. Nauk Akad. S.S.S.R., 143, Geol. Ser. 60, 204 pp. (in Russian). - Moscow.

Neves, R., 1964. Knoxisporites (Potonié and Kremp) Neves 1961. - C. R. 5e Congr. Avanc. Etud. Stratig. Carb. Paris, 1, pp. 1063-1069. - Paris.

- 1968. The palynology of the Woodland Borehole, Co. Durham. - Bull. geol. Surv. GtBr., 28, pp. 55-60. - London.

- and Belt, E. S., 1970. Some observations on Namurian and Viséan spores from Nova Scotia, Britain and northern Spain. - C. R. 6e Congr. Int. Strat. Geol. Carbonif., Sheffield 1967, 3, pp. 1233-1248. - Maastricht.

- and Dolby, G., 1967. An assemblage of miospores from the Portishead Beds (Upper Old Red Sandstone) of the Mendip Hills, England. - Pollen Spores, 9, 3, pp. 607-614. Paris.

- and Ionnnides, N., (in press.). Palynology of the Spilmersford borehole. - Bull. geol. Surv. GtBr. - London.

- and Owens, B., 1966. Some Namurian camerate miospores from the English Pennines. - Pollen Spores, 8, 2, pp. 337-360. - Paris.

- and Williams, J. E., 1970. in Day, J. B. W. Geology of the Country around Bewcastle. - Mem. geol. Surv. GtBr., pp. 172-175. - London.

Neville, R. S. W., 1968. Ranges of selected spores in the Upper Viséan of the East Fife Coast section between St. Monance and Pittenweem. - Pollen Spores, 10, 2, pp. 431-462. - Paris.

Paproth, E., 1969. Die Parallelisierung von Kohlenkalk und Kulm. - C. R. 6e Congr. Int. Strat. Geol. Carbonif., Sheffield 1967, 1, pp. 279-292. - Maastricht.

- and Streel, M., 1970. Corrélations biostratigraphiques près de la limite Dévonien/ Carbonifère entre les faciès littoraux ardennais et les faciès bathyaux rhénans. - Coll. Congr. l'Univ. Liège, 55, pp. 365-398. - Liège.

Playford, G., 1962-1963a. Lower Carboniferous microfloras of Spitsbergen. - Palaeont., 5, 3-4, pp. 550-678. - London.

- 1963b. Miospores from the Mississippian Horton Group, Eastern Canada. - Bull. Geol. Surv. Canada, 107, 47 pp. - Ottawa.

- and Barss, M. S., 1963. Upper Mississippian microflora from Axel Heiberg Island, District of Franklin. - Geol. Surv. Canada, Paper 62-36, 5 pp. - Ottawa.

PotoniÉ, R., 1956. Synopsis der Gattungen der Sporae dispersae, I. Teil: Sporites. - Beih. Geol. Jb., 23. - Hannover.

- 1958. Synopsis der Gattungen der Sporae dispersae, II. Teil: Sporites (Nachträge), Saccites, Aletes, Praecolpates, Polyplicates, Monocolpates. - Ibidem, H. 31.

- 1960. Synopsis der Gattungen der Sporae dispersae, III. Teil: Nachträge Sporites, Fortsetzung Pollenites. - Ibidem, H. 39.

- 1966. Synopsis der Gattungen der Sporae dispersae, IV. Teil: Nachträge zu allen Gruppen (Turmae). - Ibidem, H. 72. 
- 1970. Synopsis der Gattungen der Sporae dispersae, V. Teil: Nachträge zu allen Gruppen (Turmae). - Ibidem, H. 87.

- and Kremp, G., 1955. Die Sporae dispersae des Ruhrkarbons, ihre Morphographie und Stratigraphie mit Ausblicken auf Arten andere Gebiete und Zeitabschnitte. Teil I. Palaeontographica B, 98, pp. 1-136. - Stuttgart.

Richardson, J. B., 1965. Middle Old Red Sandstone spore assemblages from the Orcadian Basin north-east Scotland. - Palaeont., 7, 4, pp. 559-605. - London.

Smith, A. H. V. and Butterworth, M. A., 1967. Miospores in the coal seams of the Carboniferous of Great Britain. - Spec. Papers Palaeont., 1, 324 pp. - London.

Somers, Y. et al., in prep. Revision du genre Lycospora Schopf, Wilson et Bentall. Typewritten copy of manuscript.

Staplin, F. L., 1960. Upper Mississippian plant spores from the Golata Formation, Alberta, Canada. - Palaeontographica B, 107, pp. 1-40. - Stuttgart.

Streel, M., 1964. Une association de spores du Givétien Inférieur de la Vesdre, a Goé (Belgique). - Ann. Soc. Geol. Belg., 87, 7, pp. 233-264. - Liège.

- 1965. Techniques de préparation des roches détritiques en vue de l'analyse palynologique quantitative. - Ann. Soc. Geol. Belg., 88, 4, pp. 107-117. - Liège.

- 1966. Criteres palynologiques pour une stratigraphie détaillée du Tn la dans les Bassins ardenno-rhénans. - Ann. Soc. géol. Belg., 89, 1-4, pp. 65-96. - Liège.

- 1968. Associations de spores des stratotypes du Famennien, du Strunien et du Tournaisien dans les Bassins ardenno-rhénans. - Rev. Palaeobotan. Palynol., 5, pp. 1-4. Amsterdam.

- 1969. Corrélations palynologiques entre les sédiments de transition Dévonien/Dinantien dans les Bassins ardenno-rhénans. - C. R. 6e Congr. Int. Strat. Geol. Carbonif., Sheffield 1967, 1, pp. 3-18. - Maastricht.

- 1970. Distribution stratigraphique et géographique d'Hymenozonotriletes lepidophytus KEDO, d'Hymenozonotriletes pusillites KEDO et des assemblages tournaisiens (Synthèse du projet B). - Congr. Coll. l'Univ. Liège, 55, pp. 121-147. - Liège.

Sullivan, H. J., 1964a. Miospores from the Drybrook Sandstone and associated measures in the Forest of Dean, Gloucestershire. - Palaeont., 7, 3, pp. 351-392. - London.

- 1964b. Miospores from the Lower Limestone Shales (Tournaisian) of the Forest of Dean Basin, Gloucestershire. - C. R. 5e Congr. Int. Strat. Geol. Carbonif. Paris 1963, 3, pp. 1249-1259. - Paris.

- 1965. Palynological evidence concerning the regional differentiation of Upper Mississippian floras. - Pollen Spores, 7, pp. 539-563. - Paris.

- 1967. Regional differences in Mississippian spore assemblages. - Rev. Palaeobotan. Palynol., 1. pp. 185-192. - Amsterdam.

- 1968. A Tournaisian spore flora from the Cementstone Group of Ayrshire, Scotland. Palaeont., 11, 1, pp. 116-131. - London.

- and Marshall, A. E., 1966. Viséan spores from Scotland. - Micropaleont., 12, 3, pp. 265-285. - New York.

Utting, J. and Neves, R., 1970. Miospores from the Devonian/Carboniferous transition beds of the Avon Gorge, Bristol, England. - Congr. Coll. l'Univ. Liège, 55, pp. 411-422. - Liège.

VArma, C. P., 1969. Lower Carboniferous miospores from the Albert Oil Shales (Horton Group) of New Brunswick, Canada. - Micropaleont. 15, 3, pp. 301-324. - New York.

Winslow, M. R., 1962. Plant Spores and other Microfossils from Upper Devonian and Lower Mississippian Rocks of Ohio. - Geol. Surv. Prof. Paper, 364, 93 pp. - Washington.

Zakowa, H., 1962. (Zaręby Beds and Górno Beds (Lower Carboniferous) within the Łagow Syncline.) - Geol. Inst. Biul., 174, pp. 161-222 (in Polish w/English Résumé). Warszawa. 
PLATES 


\section{PLATE I}

$\times 500$

D.G.U. Text Catalogue No. page

Figs. 1-2. Leiotriletes ornatus Ischenko. . . . . . . . . . . . . 1972-FB-1 24 $7743^{\prime \prime} 0^{\prime \prime}$, S1 268 SM.

Distal view. Fig. 1: low focus, fig. 2: high focus.

Diameter : $46 \mu$.

Fig. 3. Leiotriletes? sp. (S1 291 SM)

1972-FB-2 7743'0", S1 291 SM.

Proximal view.

Diameter: $41 \mu$.

Figs. 4-5. Punctatisporites? sp. (S1 289 SM) .

1972-FB-3

7743'0", S1 289 SM.

Distal view. Fig. 4: low focus, fig. 5: high focus.

Diameter : $62 \mu$.

Figs. 6-7. Punctatisporites platirugosus (Waltz) Sullivan var.

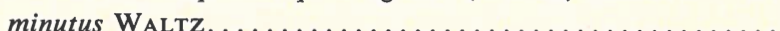
$7743^{\prime \prime} 0^{\prime \prime}$, S1 281 SM.

1972-FB-4 27

Distal view. Fig. 6: low focus, fig. 7 : high focus.

Diameter : $46 \mu$.

Fig. 8. Punctatisporites glaber (NAumova) Playford

1972-FB-5 26 7739'4-9", S1 279 SM.

Proximal view.

Diameter : $60 \mu$.

Fig. 9. Leiotriletes sp. (S1 $412 \mathrm{SM})$

1972-FB-6

$7743^{\prime} 0^{\prime \prime}$, Sl 412 SM.

Proximal view.

Diameter: $75 \mu$.

Fig. 10. Punctatisporites glaber (NAumova) Playford

1972-FB-7 26 $7743^{\prime} 0^{\prime \prime}$, Sl 276 SM.

Proximal view.

Diameter : $66 \mu$. 
Plate 1
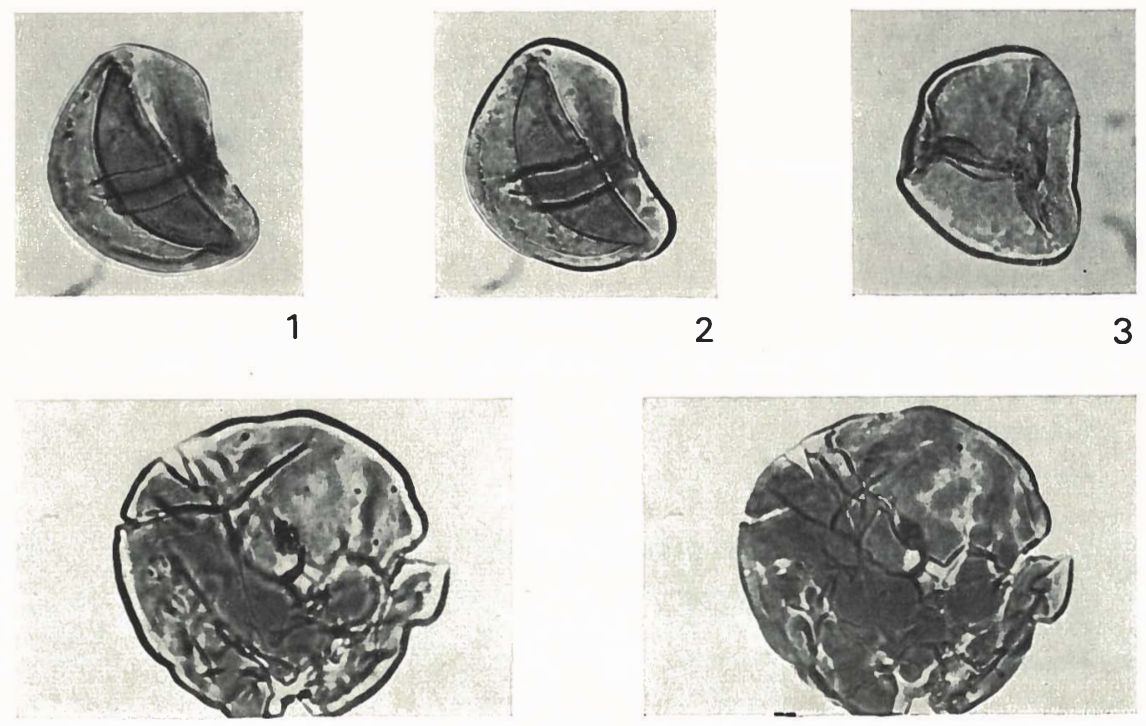

4

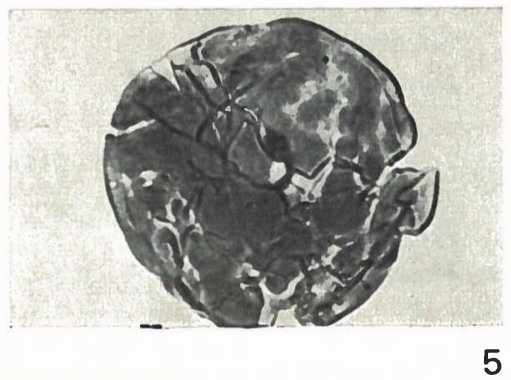

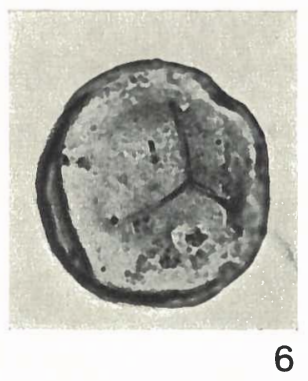

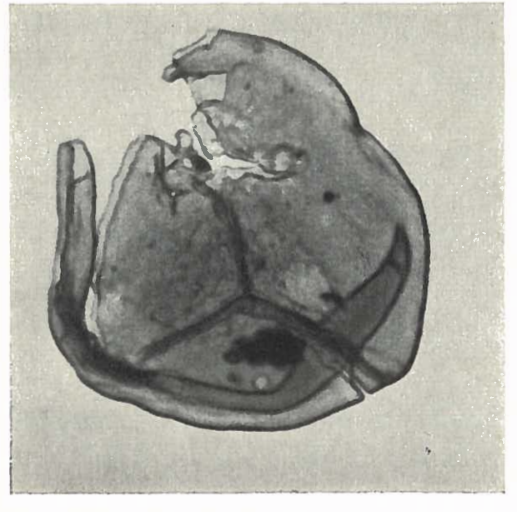

9

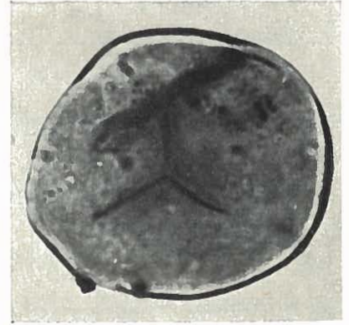

8

7

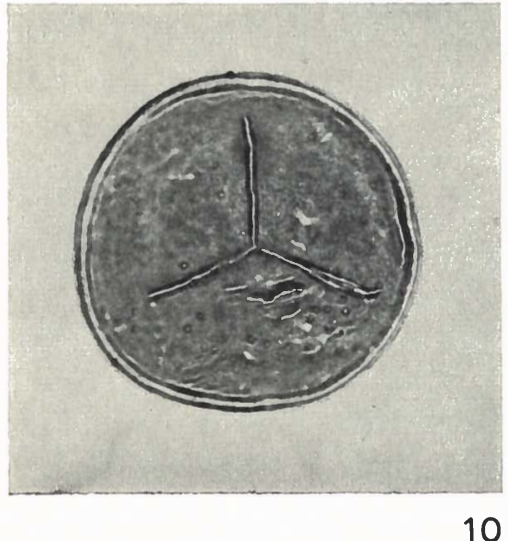

6 D.G.U. II. rk. nr. 99 
D.G.U. Text Catalogue No. page 1972-FB-8

Fig. 1. Punctatisporites pseudolevatus Hoffm., Stapl. and Mall. $7743^{\prime} 0^{\prime \prime}$, S1 391 SM.

Proximal view.

Diameter: $77 \mu$.

Fig. 2. Punctatisporites cf. limbatus Hacquebard

1972-FB-9

26 $7743^{\prime} 0^{\prime \prime}$, S1 280 SM.

Proximal view.

Diameter: $78 \mu$.

Fig. 3. Punctatisporites sp. (Sl 361 SM).

1972-FB-10

7739'4-9'", S1 361 SM.

Proximal view.

Diameter: $78 \mu$.

Fig. 4. Punctatisporites sp. (S1 361 SM)

1972-FB-11 28

$7743^{\prime} 0^{\prime \prime}$, SI 392 SM.

Proximal view.

Diameter: $76 \mu$.

Fig. 5. Punctatisporites aff. aerarius Butterworth and Williams 1972-FB-12 7739'4-9"'S1 360.

Proximal-equatorial view.

Diameter: $63 \mu$.

Fig. 6. Convolutispora finis Love.

1972-FB-13 43 7739'4-9"', S1 368 SM.

Proximal view.

Diameter : $80 \mu$. 
Plate II
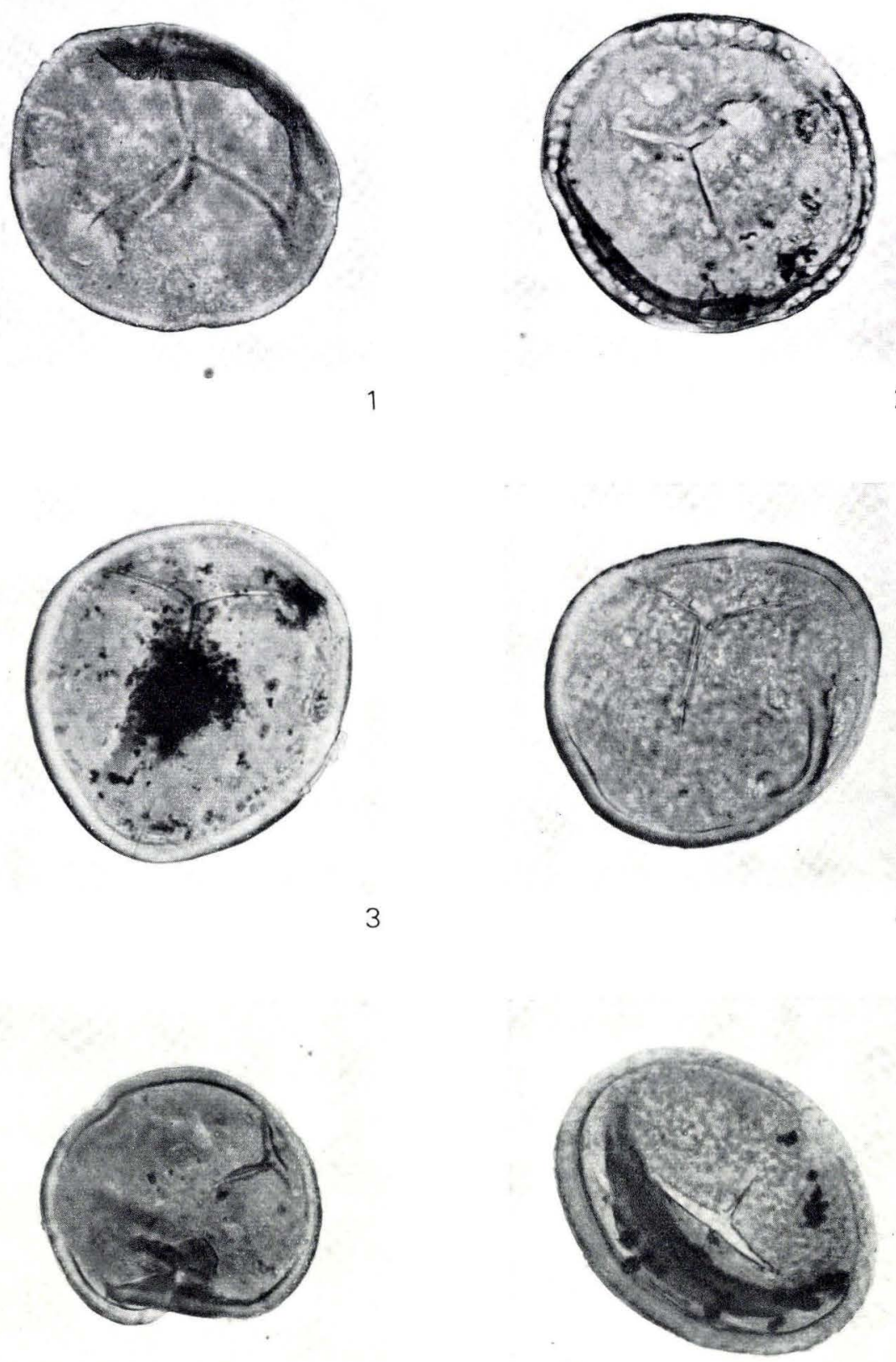
Fig. 1. Retusotriletes? sp. (S1 353 SM).

D.G.U. Text $7743^{\prime} 0^{\prime \prime}$, SI $353 \mathrm{SM}$.

Proximal view.

Diameter : $95 \mu$.

Fig. 2. Cyclogranisporites cf. commodus PLAYFORD .......... 1972-FB-15 $7739^{\prime} 4-9^{\prime \prime}$, S1 384 SM.

Defective tetrad.

Diameters: $40-42 \mu$.

Fig. 3. Baculatisporites fusticulus Sullivan............. 1972-FB-16 $7743^{\prime} 0^{\prime \prime}$, Sl 416 SM.

Proximal view.

Diameter: $69 \mu$.

Fig. 4. Baculatisporites fusticulus Suldivan............ 1972-FB-17 7739'4-9', Sl 385 SM.

Distal view.

Diameter: $73 \mu$.

Figs. 5-6. Granulatisporites sp. (S1 415 SM)

$7743^{\prime} 0^{\prime \prime}$, Sl 415 SM.

Proximal view. Fig. 5: high focus, fig. 6: low focus.

Diameter: $41 \mu$.

Figs. 7-8. Cyclogranisporites ef. commodus PLAYFORD

1972-FB-19

7719'5", S1 009 PM: 6.5-121.3.

Proximal view. Fig. 7: low focus, fig. 8: high focus.

Diameter: $40 \mu$.

Fig. 9. Verrucosisporites nitidus (NAUMOVA) Playford. $7743^{\prime} 0^{\prime \prime}$, S1 $257 \mathrm{SM}$.

Equatorial view.

Diameter: $43 \mu$.

Fig. 10. Verrucosisporites nitidus (NAUMOVA) PLAYFord. $7743^{\prime} 0^{\prime \prime}$, SI 256 SM.

Proximal-equatorial view.

Diameter : $43 \mu$. 
Plate III
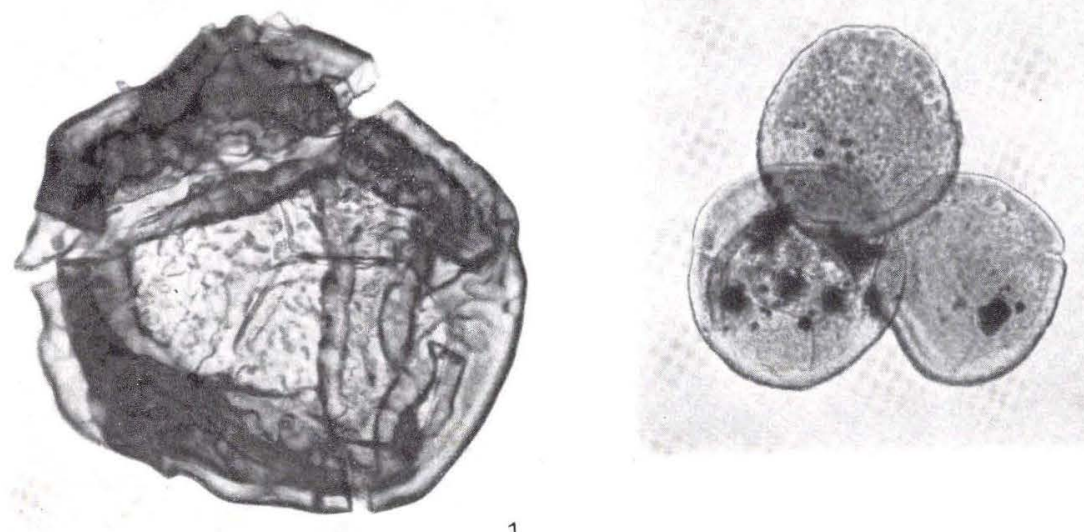

1
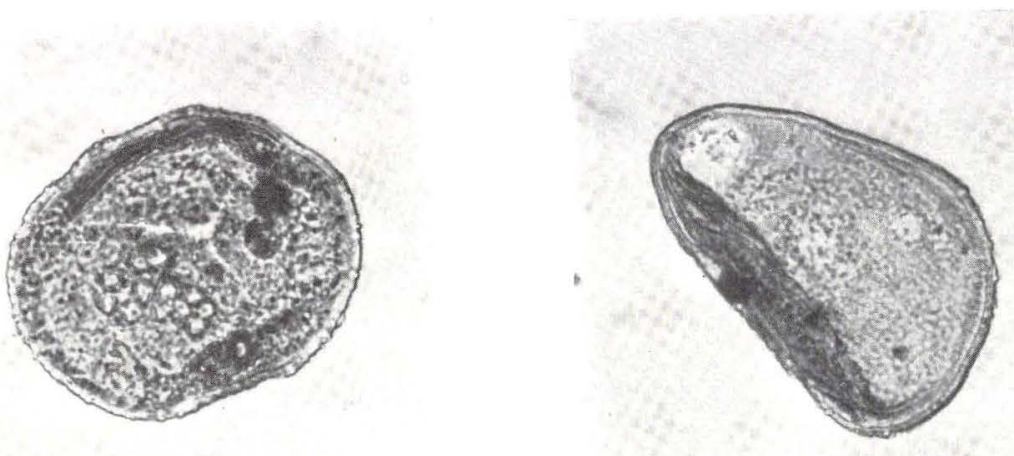

3
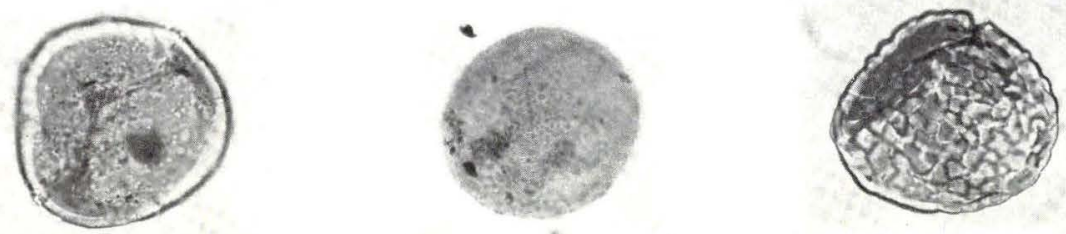

5

4
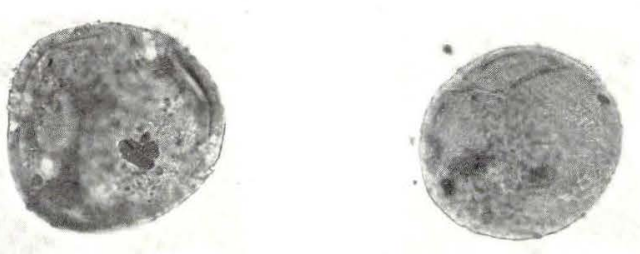

6

8

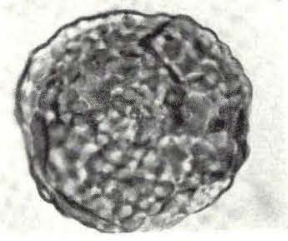


PLATE IV

$\times 500$ (fig. $4, \times 1000$ )

D.G.U. Text

Catalogue No. page

Fig. 1. Apiculatisporites sp. (S1 $238 \mathrm{SM}$ ) 1972-FB-22 36 7739'4-9', S1 242 SM.

Distal? view.

Diameter: $108 \mu$.

Fig. 2. Apiculatisporites sp. (S1 238 SM)

7743'0', SH-14-FB.

Scanning micrograph, distal view.

Diameter: Appr. $90 \mu$.

Fig. 3. Verrucosisporites sp. (S1 408 SM)

$7743^{\prime} 0^{\prime \prime}$, S1 408 SM.

Distal view.

Diameter: $62 \mu$. excl. sculpture.

Fig. 4. Schopfites claviger Sullivan. . . . . . . . . . . . . 1972-FB-25

$7743^{\prime} 0^{\prime \prime}, \mathrm{SH}-5-\mathrm{FB}$, No. 15.

Scanning micrograph, proximal view, $\times 1000$.

Diameter: $49 \mu$ excl. sculpture.

Fig. 5. Verrucosisporites scoticus Sullivan.

1972-FB-26 7739'4-9', S1 216 SM.

Distal view.

Diameter: $46 \mu$, excl. sculpture.

Fig. 6. Schopfites claviger Sullivan. . . . . . . . . . . . . 1972-FB-27 $7743^{\prime} 0^{\prime \prime}$, S1 267 SM.

Distal view.

Diameter: $47 \mu$, excl. sculpture.

Fig. 7. Schopfites claviger SULLIVAN $7743^{\prime} 0^{\prime \prime}$, S1 266 SM.

Equatorial view.

Diameter: $44 \mu$, excl. sculpture. 


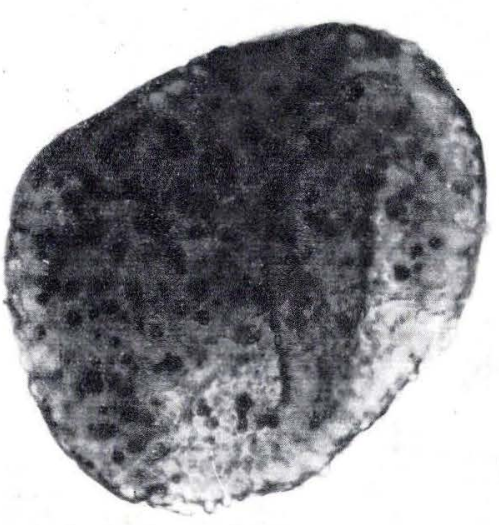

1

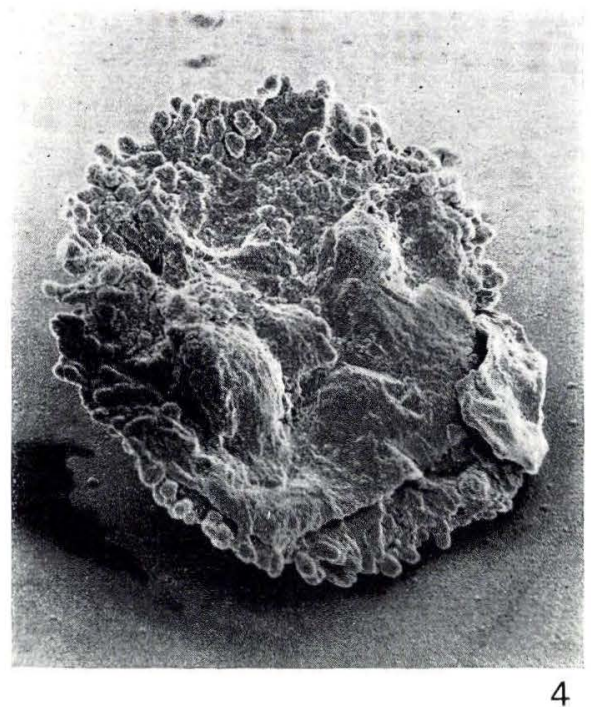

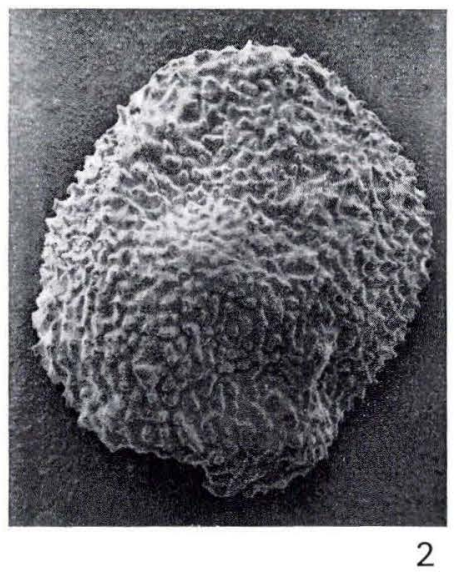

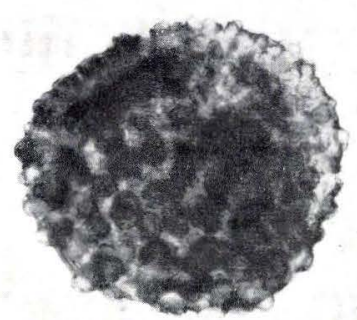

3

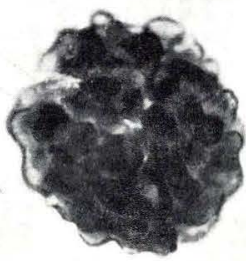

5
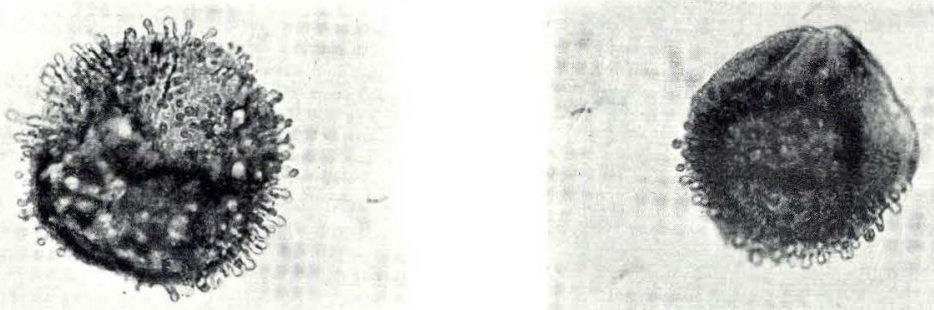


\footnotetext{
PLATE V

$\times 500$ (fig. $6, \times 5000)$
}

Figs. 1-2. Lophotriletes linguaeformis n. sp. 7739'4-9", S1 250 SM. Holotype.

Distal view. Fig. 1: high focus, fig. 2: low focus.

Diameter: $51 \mu$, excl. sculpture.

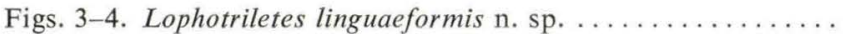

7739'4-9', S1 244 SM.

Equatorial-proximal view. Fig. 3 : high focus, fig. 4 : low focus.

Diameter: $58 \mu$, excl. sculpture.

Figs. 5-6. Lophotriletes linguaeformis n. sp. ............ 1972-FB-31

$7743^{\prime} 0^{\prime \prime}, \mathrm{SH}-17-\mathrm{FB}$, No. 1.

Scanning micrographs, proximal view.

Fig. 5: $\times 500$, fig. 6: $\times 5000$.

Diameter: $56 \mu$, excl. sculpture.

Fig. 7. Anaplanisporites baccatus (Hoffm., Stapl. and Mall.)

$7743^{\prime} 0^{\prime \prime}$, S1 399 SM.

1972-FB-32

Distal view.

Diameter: $28 \mu$.

Fig. 8. Anaplanisporites sp. (S1 302 SM)

1972-FB-33

7743'0", S1 302 SM.

Proximal view.

Diameter: $32 \mu$.

Fig. 9. Lophotriletes tribulosus Sullivan. . . . . . . . . . . . . . . 1972-FB-34

$7743^{\prime} 0^{\prime \prime}$, S1 405 SM.

Proximal-equatorial view.

Diameter: $34 \mu$, excl. sculpture.

Fig. 10. Anaplanisporites? cf. globulus (BUTterworTH and WIL-

LIAMS) SMITH and BUTTERWORTH. . . . . . . . . . . . . $7743^{\prime} 0^{\prime \prime}$, S1 404 SM.

$1972-$ FB-35

Distal view.

Diameter: $28 \mu$. 
Plate V
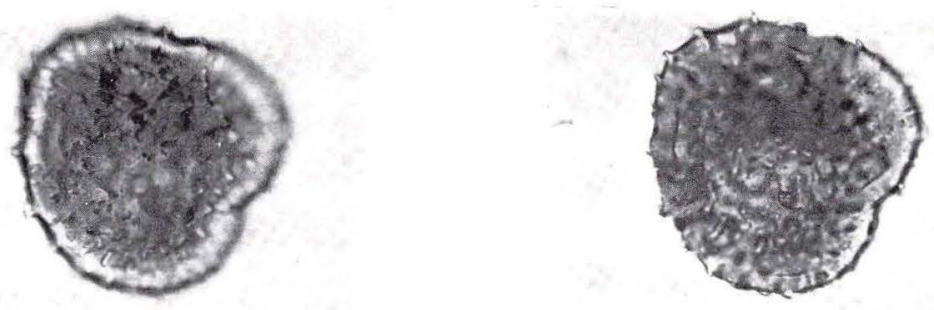

1
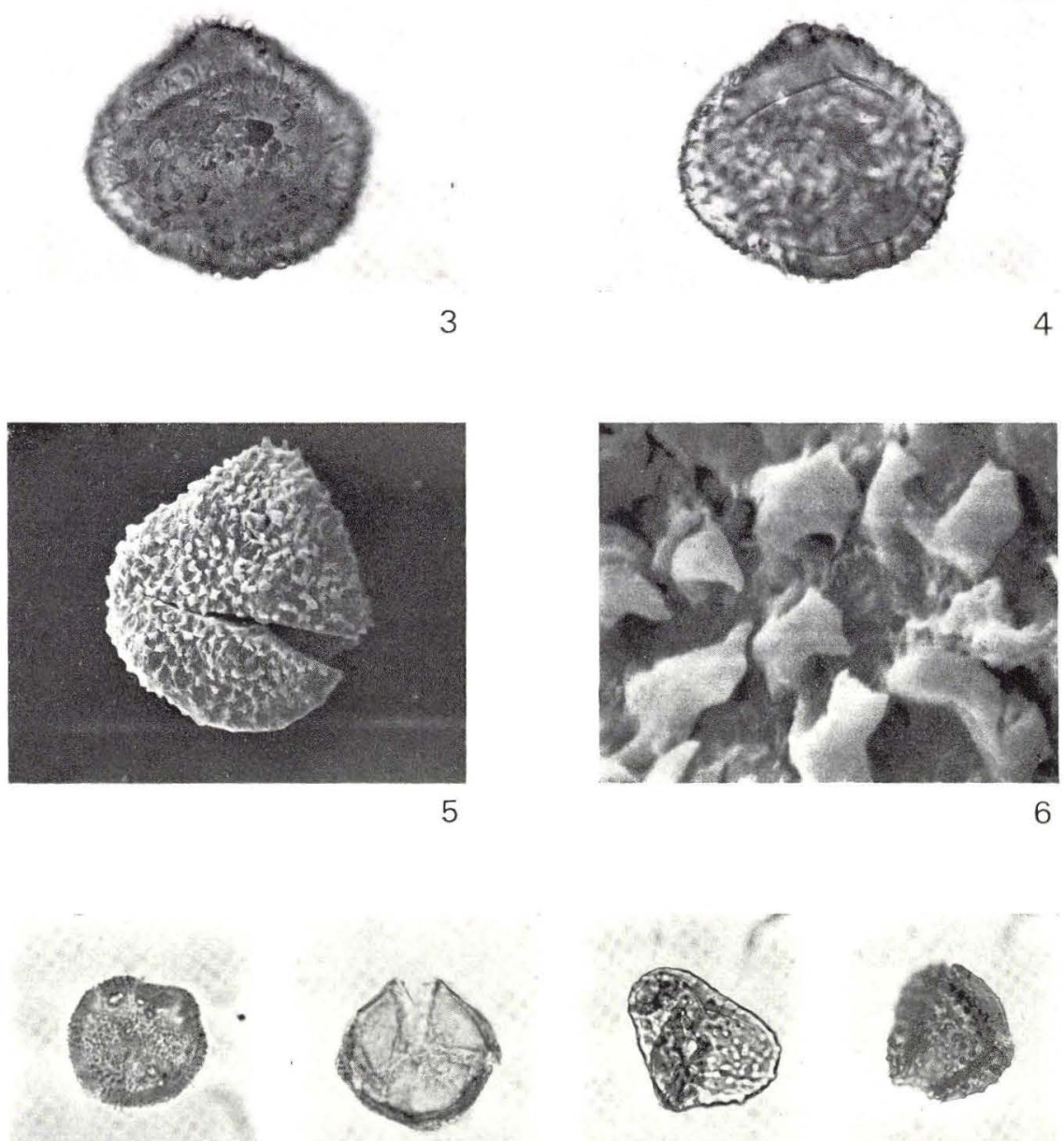
Fig. 1. Anaplanisporites baccatus (HoffM., Stapl. and Mall.)

D.G.U. Text Catalogue No. page

SMith and Butterworth...................

$7743^{\prime} 0^{\prime \prime}, \mathrm{SH}-6-\mathrm{FB}, \mathrm{c}$.

Scanning micrograph, proximal view, $\times 1500$.

Diameter: appr. $30 \mu$.

Fig. 2. Anaplanisporites baccatus (Hoffm., Stapl. and Mall.) SMITH and ButTERworth.................... $7743^{\prime} 0^{\prime \prime}, \mathrm{SH}-6-\mathrm{FB}$, a.

Scanning micrograph, equatorial-proximal view, $\times 1750$.

Diameter: appr. $30 \mu$.

Figs. 3-4. Anaplanisporites baccatus (Hoffm., StAPl. and Mall.)

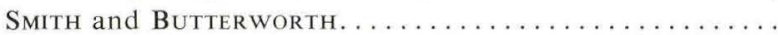

$7743^{\prime} 0^{\prime \prime}, \mathrm{SH}-6-\mathrm{FB}, \mathrm{b}$.

$1972-\mathrm{FB}-38$

Fig. 3: Scanning micrograph, distal view, $\times 1400$.

Fig. 4: Scanning micrograph, equatorial view, $\times 2600$.

Diameter: appr. $30 \mu$.

Figs. 5-6. Anaplanisporites sp. (S1 302 SM)

1972-FB-39

$7743^{\prime} 0^{\prime \prime}, \mathrm{SH}-6-\mathrm{FB}, \mathrm{d}$.

Fig. 5: Scanning micrograph, equatorial view, $\times 1700$.

Fig. 6: Scanning micrograph, dist. surface section, $\times 4300$.

Diameter: appr. $30 \mu$.

Phot. J. Fuglsang. 
Plate VI

D.G.U. Text Catalogue No. page

Figs. 1-2. Pustulatisporites multicapitis n. sp............ 1972-FB-40 35 $7743^{\prime} 0^{\prime \prime}$, SH-5-FB, No. 65.

Fig. 1: Scanning micrograph, $\times 1000$.

Fig. 2: Scanning micrograph, equatorial section, $\times 3000$.

Diameter: appr. $60 \mu$, excl. sculpture.

Fig. 3. Pustulatisporites multicapitis n. sp............. 1972-FB-41 7743'0", S1 272 SM.

Proximal view, $\times 500$.

Diameter : $66 \mu$, excl. sculpture.

Fig. 4. Pustulatisporites multicapitis n. $\mathrm{sp}$ $7743^{\prime} 0^{\prime \prime}$, S1 273 SM.

Holotype, proximal view, $\times 500$.

Diameter: $63 \mu$, excl. sculpture.

Figs. 5-6. Pustulatisporites multicapitis n. sp.

Fig. 5: Scanning micrograph, $\times 700$.

Fig. 6: Scanning micrograph, $\times 2900$, central section.

Diameter: appr. $60 \mu$, excl. sculpture.

Figs. 5-6: Phot. J. Fuglsang. 
Plate VII
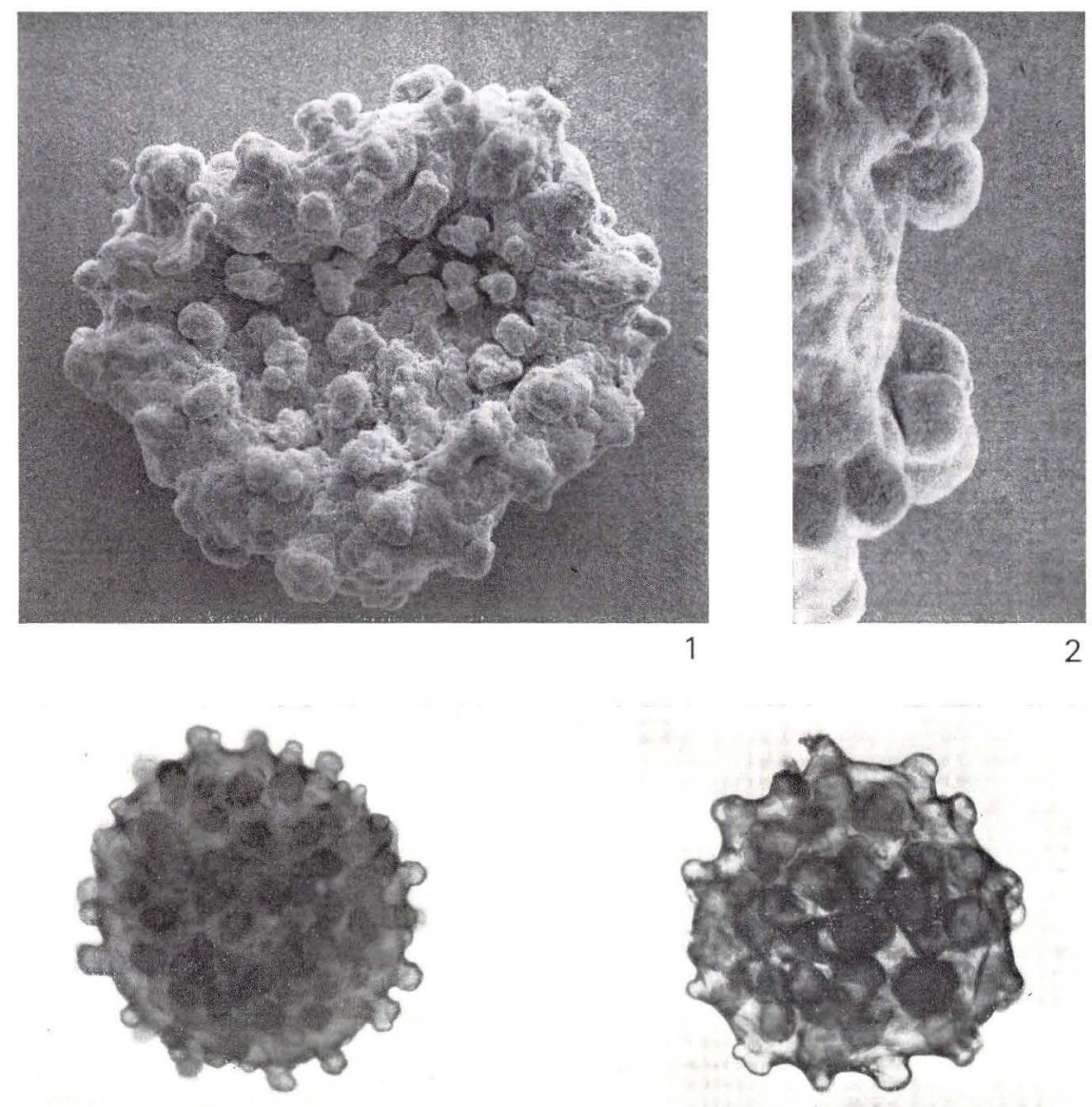

3

4
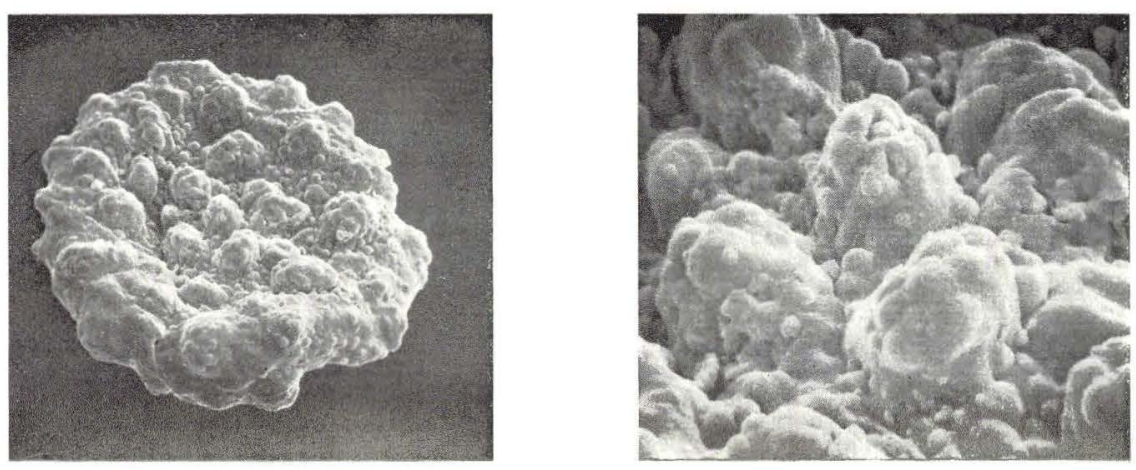

5 
PLATE VIII

$\times 500$ (fig. $2, \times 550$ )

D.G.U. Text

Catalogue No. page

Fig. 1. Umbonatisporites distinctus Clayton ............ 1972-FB-44 40 6950'-6960', S1 024 PM: 13.0-117.6.

Proximal view.

Diameter: $54 \mu$.

Fig. 2. Apiculiretusispora sp. (S1 304 SM)

$1972-F B-45$

7743'0", SH-7-FB.

Scanning micrograph, proximal view, $\times 550$.

Diameter: $76 \mu$.

Figs. 3-4. Apiculiretusispora sp. (S1 304 SM)

1972-FB-46

7743'0", Sl 304 SM.

Proximal view. Fig. 3: high focus, fig. 4: low focus.

Diameter: $70 \mu$.

Figs. 5, 7. Apiculiretusispora multiseta (Luber) BUtTerworth

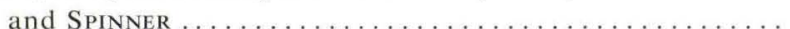
7743'0", S1 403 SM.

$1972-\mathrm{FB}-47$

Distal view. Fig. 5: high focus, fig. 7: low focus.

Diameter: $39 \mu$, excl. sculpture.

Figs. 6, 8. Acanthotriletes spinosus (WALTz) IscHENKo ........ $7743^{\prime} 0^{\prime \prime}$, SI $409 \mathrm{SM}$.

Distal? view. Fig. 6: high focus, fig. 8: low focus.

Diameter: $40 \mu$, excl. sculpture.

Fig. 2: Phot. J. Fuglsang. 

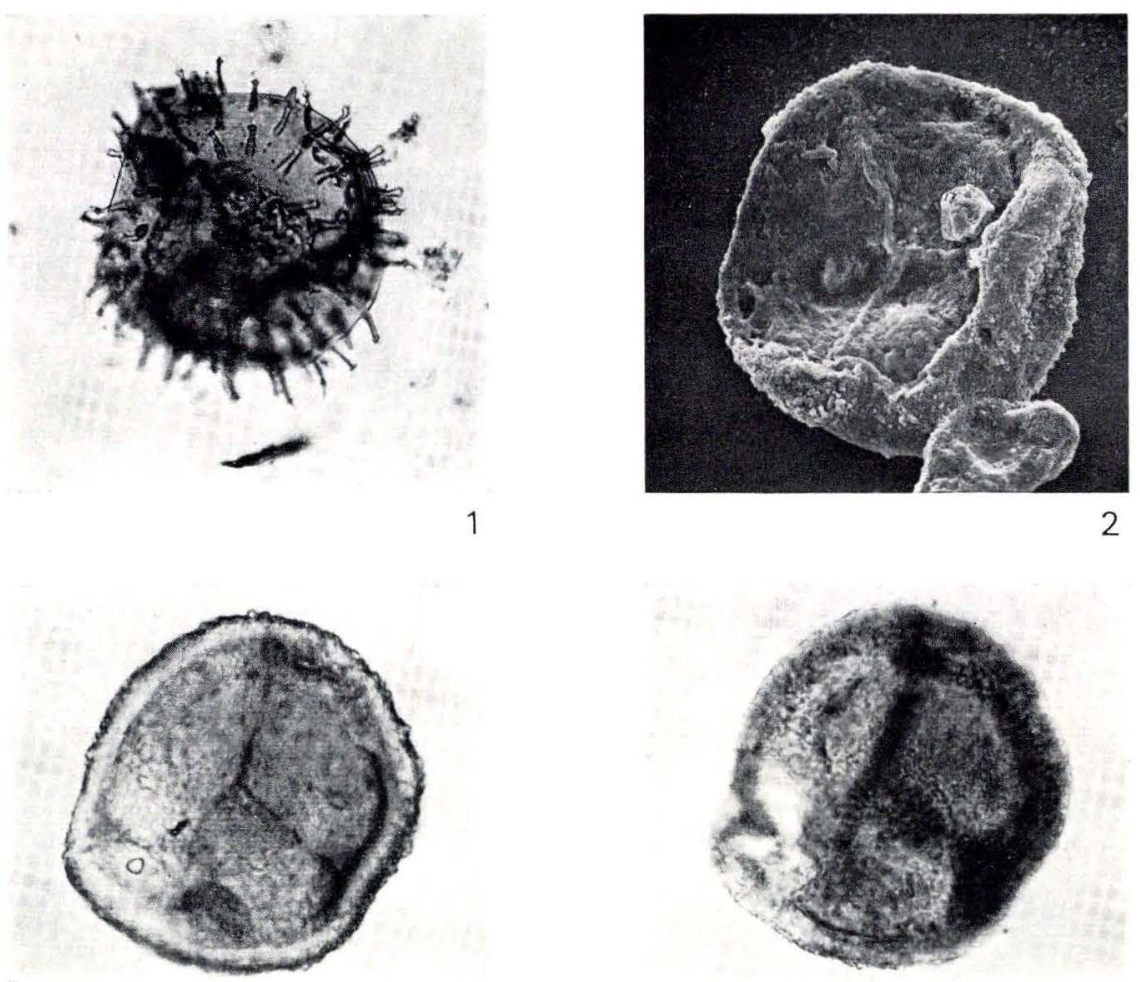

4
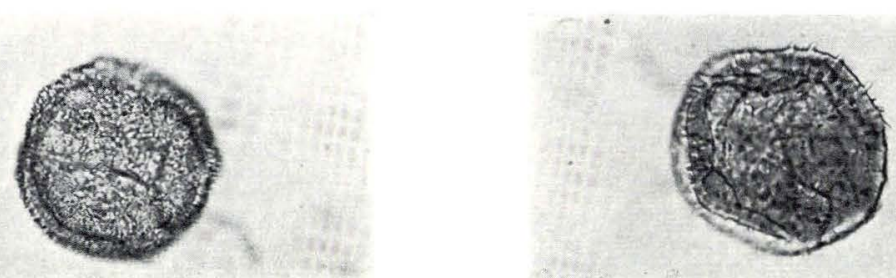

5
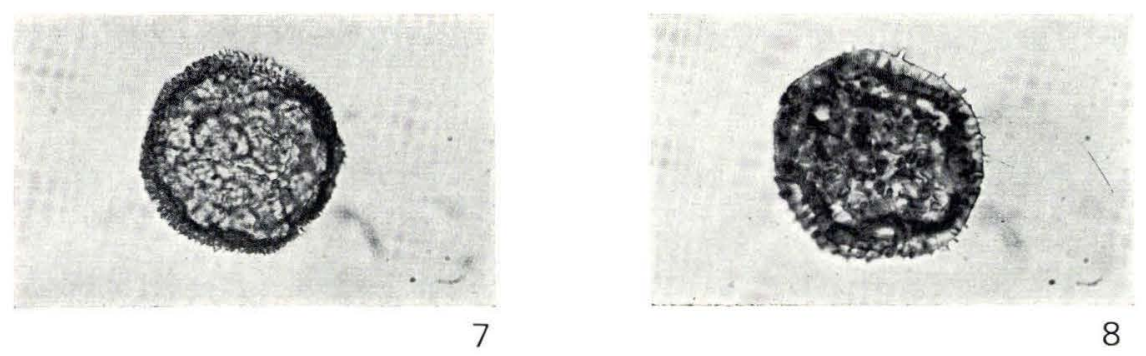
PLATE IX

$\times 500$ (fig. $8, \times 800$ )

Fig. 1. Raistrickia corynoges Sullivan. . . . . . . . . . . . 1972-FB-49 39

$7743^{\prime} 0^{\prime \prime}$, SH-13-FB, No. 2.

Scanning micrograph, proximal view, $\times 500$.

Diameter: appr. $60 \mu$, excl. sculpture.

Figs. 2-3. Raistrickia nigra Love ................. 1972-FB-50

$7743^{\prime} 0^{\prime \prime}$, Sl 002 PM: 11.8-130.2.

Distal view. Fig. 2: high focus, fig. 3: low focus.

Diameter: $47 \mu$, excl. sculpture.

Fig. 4. Raistrickia corynoges Sullivan ............. 1972-FB-51

$7743^{\prime} 0^{\prime \prime}$, SH-5-FB, No. 33.

Scanning micrograph, distal view, $\times 500$.

Diameter: appr. $70 \mu$, excl. sculpture.

Fig. 5. Cristatisporites echinatus PlAyFORD............ 1972-FB-52

7743'0", S1 002 PM: 7.7-130.2.

Equatorial view.

Diameter : $75 \mu$.

Fig. 6. Baculatisporites sp. (S1 243 SM) . . . . . . . . . . . . . 1972-FB-53

7739'4-9', Sl 243 SM.

Proximal-equatorial view.

Diameter: $54 \mu$, excl. sculpture.

Fig. 7. Baculatisporites sp. (S1 $243 \mathrm{SM})$

1972-FB-54

$7743^{\prime} 0^{\prime \prime}$, SH-5-FB, No. 2.

Scanning micrograph, distal view, $\times 500$.

Diameter: appr. $50 \mu$, excl. sculpture.

Fig. 8. Cristatisporites echinatus Playford............. 1972-FB-55

$7743^{\prime} 0^{\prime \prime}$, SH-5-FB, No. 6.

Scanning micrograph, proximal-equatorial view, $\times 800$.

Diameter: appr. $55 \mu$.

Figs. 4, 7, 8: Phot. A. NøRGÅrD. 
Plate IX
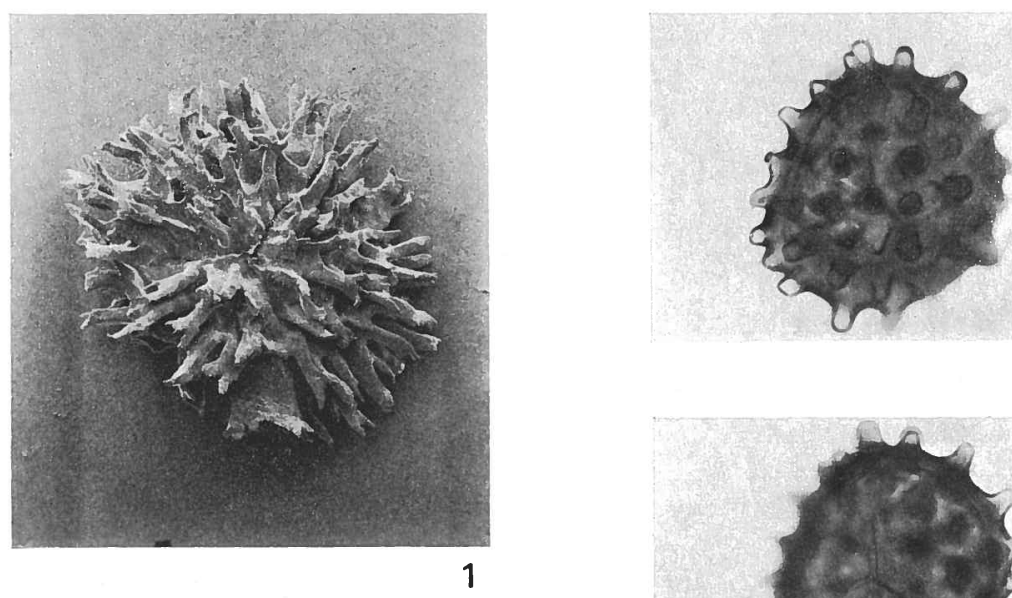

2
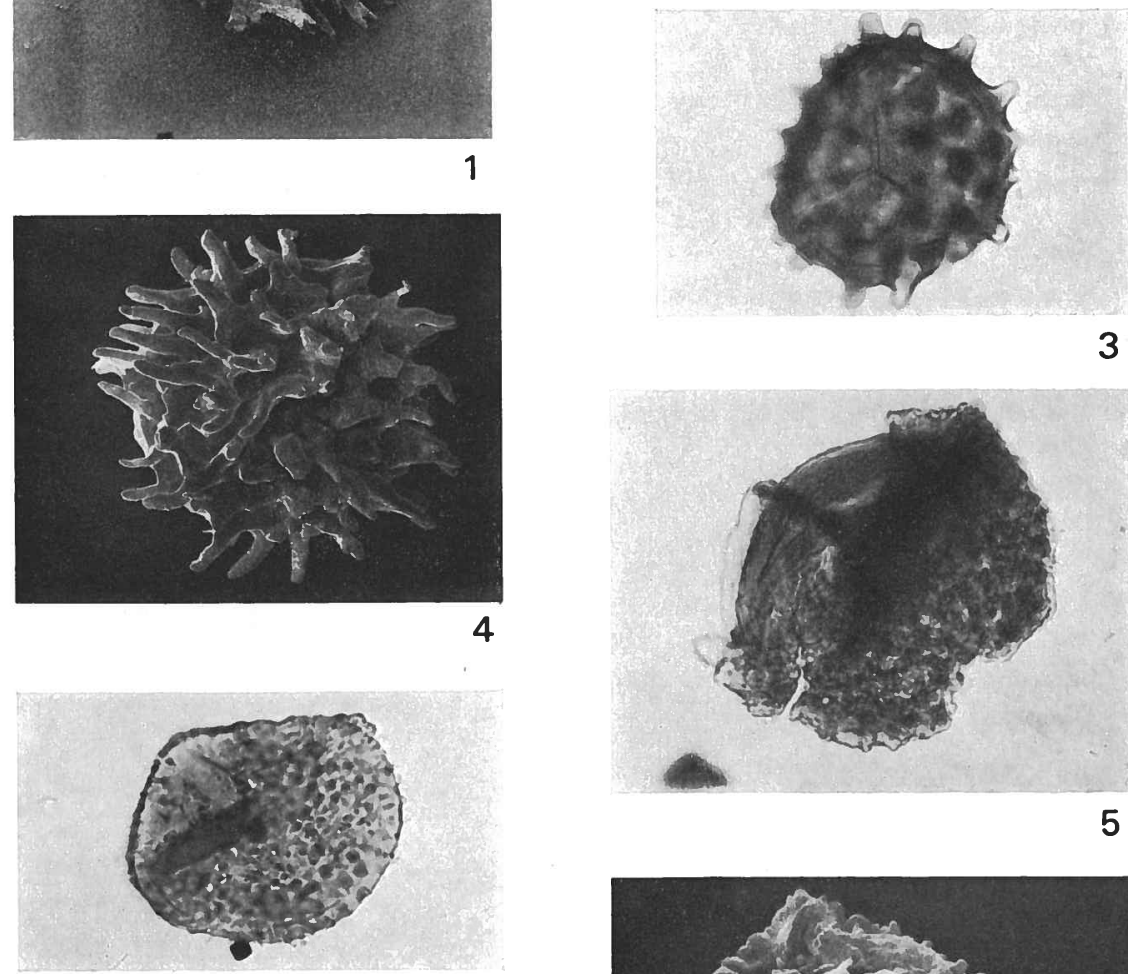

5

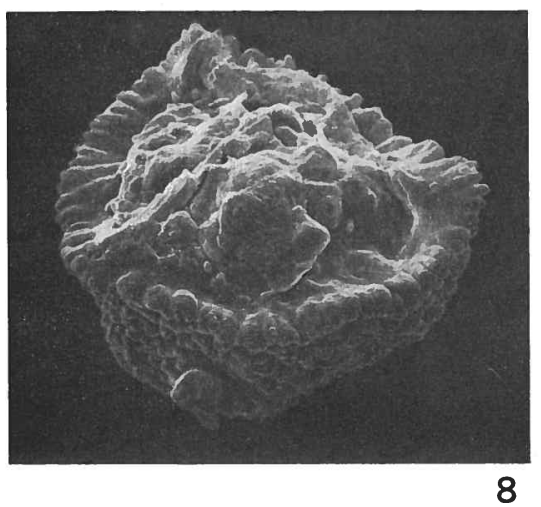

7 D.G.U. II. rk. nr. 99 


\section{PLATE X}

$\times 500$

Fig. 1. Convolutispora amplecta (LuBER) J ACHOwICz f. kasachstanensis LUBER . 7739'4-9", S1 245 SM.

Distal view.

Diameter: $67 \mu$.

Fig. 2. Convolutispora amplecta (LUBER) JACHOWICZ f. kasachstanensis LUBER ........................... $7743^{\prime} 0^{\prime \prime}$, SH-9-FB.

Scanning micrograph, distal view.

Diameter: appr. $80 \mu$.

Fig. 3. Convolutispora sp. (S1 $222 \mathrm{SM}$ )

$1972-$ FB-58

$7743^{\prime} 0^{\prime \prime}, \mathrm{SH}-5-\mathrm{FB}$, No. 23

Scanning micrograph, distal view.

Diameter: appr. $60 \mu$.

Fig. 4. Convolutispora sp. (SI 222 SM).

$1972-F B-59$

$7739^{\prime} 4-9^{\prime \prime}$, S1 222 SM.

Proximal view.

Diameter: $75 \mu$.

Fig. 5. Convolutispora sp. (S1 222 SM).

$1972-$ FB-60

$7743^{\prime} 0^{\prime \prime}, \mathrm{SH}-4-\mathrm{FB}$, No. 1.

Scanning micrograph, equatorial view, distal pole to the left. Diameter: appr. $65 \mu$.

Fig. 6. Convolutispora aff. crassa PlAyFord

1972-FB-61 $7716^{\prime} 0-7^{\prime \prime}$, S1 220 SM.

Proximal view.

Diameter: $68 \mu$.

Fig. 7. Convolutispora sp. (S1 227 SM).

1972-FB-62

Proximal view.

Diameter : $90 \mu$

Fig. 2: Phot. Owajaki; figs. 3, 5: Phot. A. NørGÅRD. 
Plate X

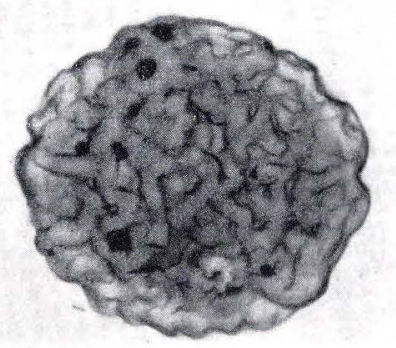

1
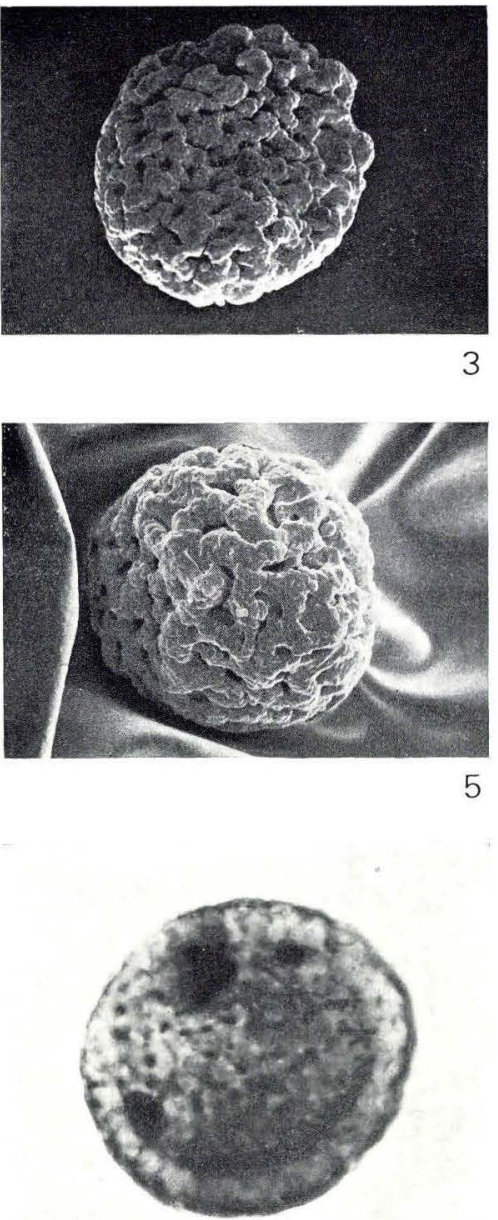

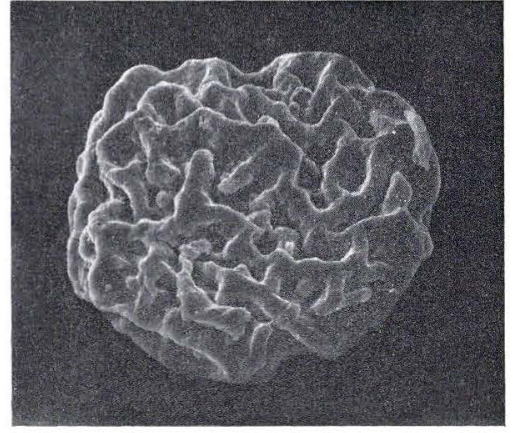

2

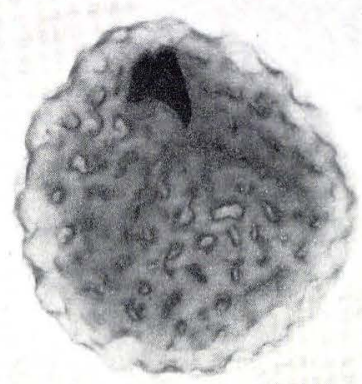

4

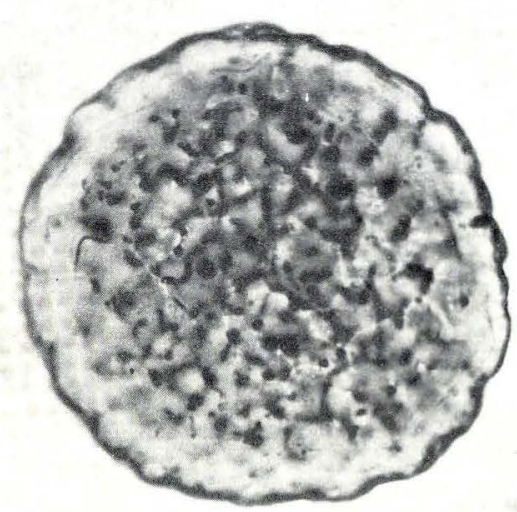

7 
PLATE XI

$\times 500$

D.G.U. Text Catalogue No. page

Fig. 1. Convolutispora sp. (S1 $227 \mathrm{SM})$ 1972-FB-63

7716'0-7', K 2,1: 11.2-128.2.

Proximal view.

Diameter: $86 \mu$.

Fig. 2. Convolutispora vermiformis HugheS and PLAYFORD.....

1972-FB-64 44 $7716^{\prime} 0-7^{\prime \prime}$, S1 239 SM.

Distal view.

Diameter: $71 \mu$.

Fig. 3. Convolutispora turgida n. sp.................. 1972-FB-65 43 7739'4-9', S1 319 SM.

Holotype, proximal view.

Diameter: $133 \mu$.

Fig. 4. Convolutispora ef. vermiformis Hughes and Playford... 7739'4-9", S1 233 SM.

Proximal view.

Diameter: $37 \mu$.

Fig. 5. Convolutispora turgida n. sp.

1972-FB-67 43 7716'0-7'”, S1 318 SM.

Proximal view.

Diameter: $149 \mu$. 
Plate XI
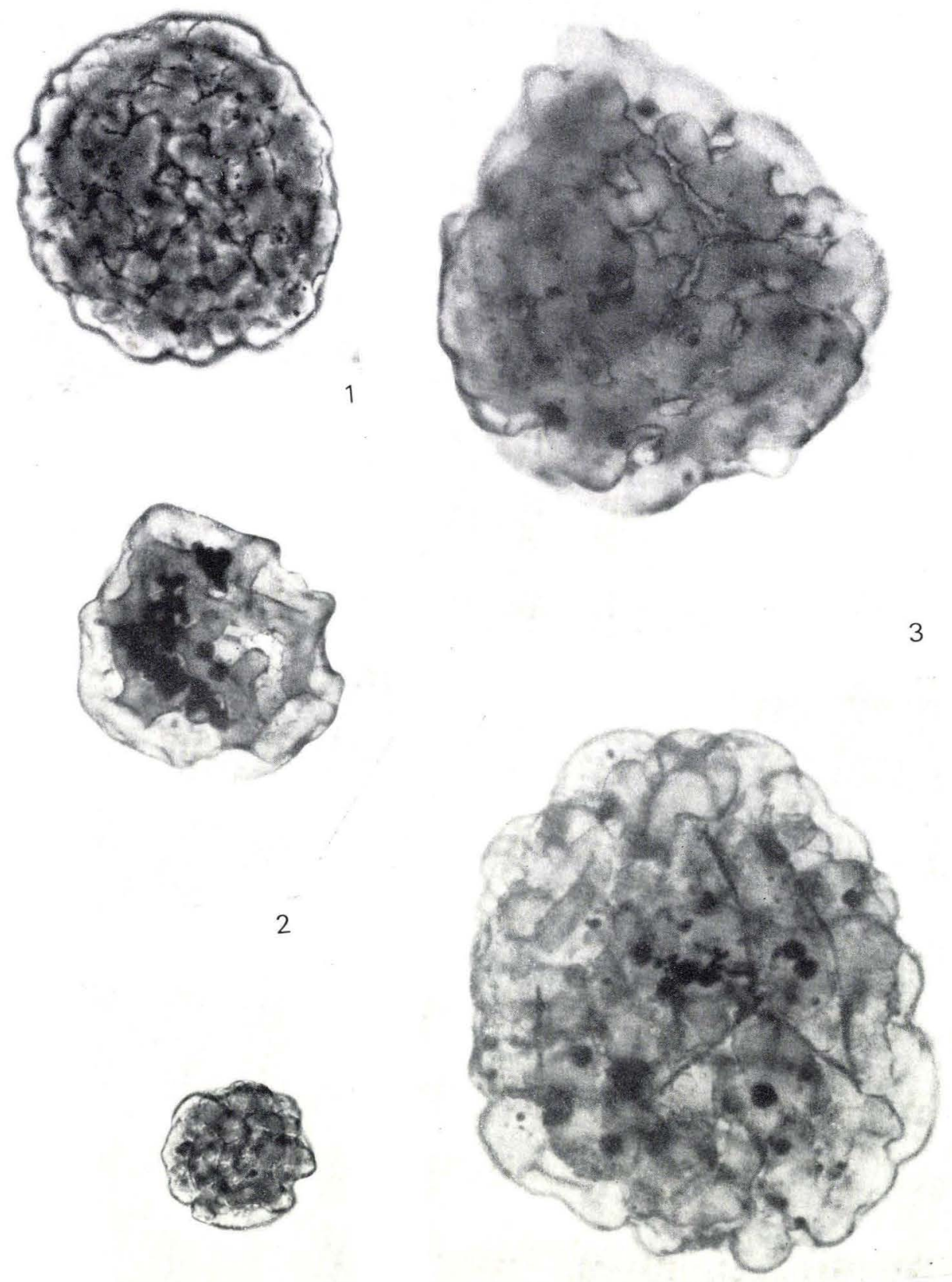


\section{PLATE XII}

$\times 500$ (fig. $1, \times 1000$; fig. $2, \times 1050$ )

D.G.U. Text Catalogue No. page

Fig. 1. Rugospora minuta Neves and IOANNIDES. 1972-FB-68

$7743^{\prime} 0^{\prime \prime}$, SH-5-FB, No. 19.

Scanning micrograph, $\times 1000$.

Diameter: appr. $45 \mu$.

Fig. 2. Rugospora minuta Neves and IoANNIDES $7743^{\prime} 0^{\prime \prime}, \mathrm{SH}-4-\mathrm{FB}$, No. 8.

Scanning micrograph, $\times 1050$.

Diameter: appr. $40 \mu$.

Fig. 3. Rugospora minuta Neves and IoAnnides. . . . . . . . . 1972-FB-70

7739'4-9', S1 329 SM.

Proximal view.

Diameter: $42 \mu$.

Fig. 4. Rugospora minuta Neves and IoAnNides. . . . . . . . . . 1972-FB-71

7743'0", S1 309 SM.

Proximal view.

Diameter : $46 \mu$.

Fig. 5. Convolutispora densorugosa n. sp............. 1972-FB-72

$7716^{\prime} 0-7^{\prime \prime}$, S1 254 SM.

Holotype, proximal view.

Diameter : $88 \mu$.

Fig. 6. Convolutispora densorugosa n. sp.

1972-FB-73

7716'0-7', K 2.1: 4.1-128.2.

Proximal view.

Diameter: $80 \mu$.

Fig. 7. Convolutispora densorugosa n. sp.............. 1972-FB-74

$7716^{\prime} 0-7^{\prime \prime}, \mathrm{SH}-15-\mathrm{FB}$, No. 3.

Scanning micrograph, proximal view, $\times 500$.

Diameter: appr. $80 \mu$.

Fig. 2: Phot. A. NøRGÅRD. 
Plate XII

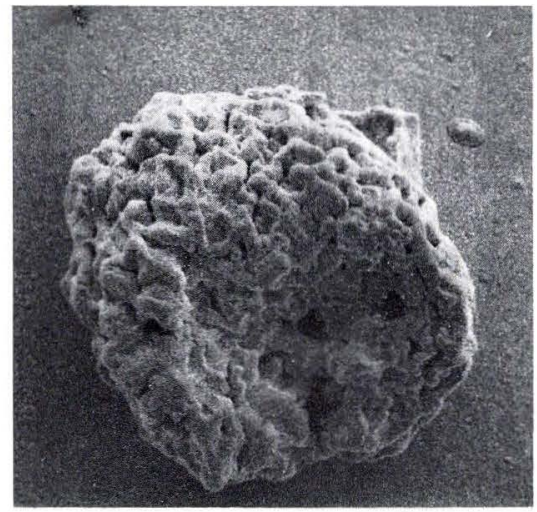

1
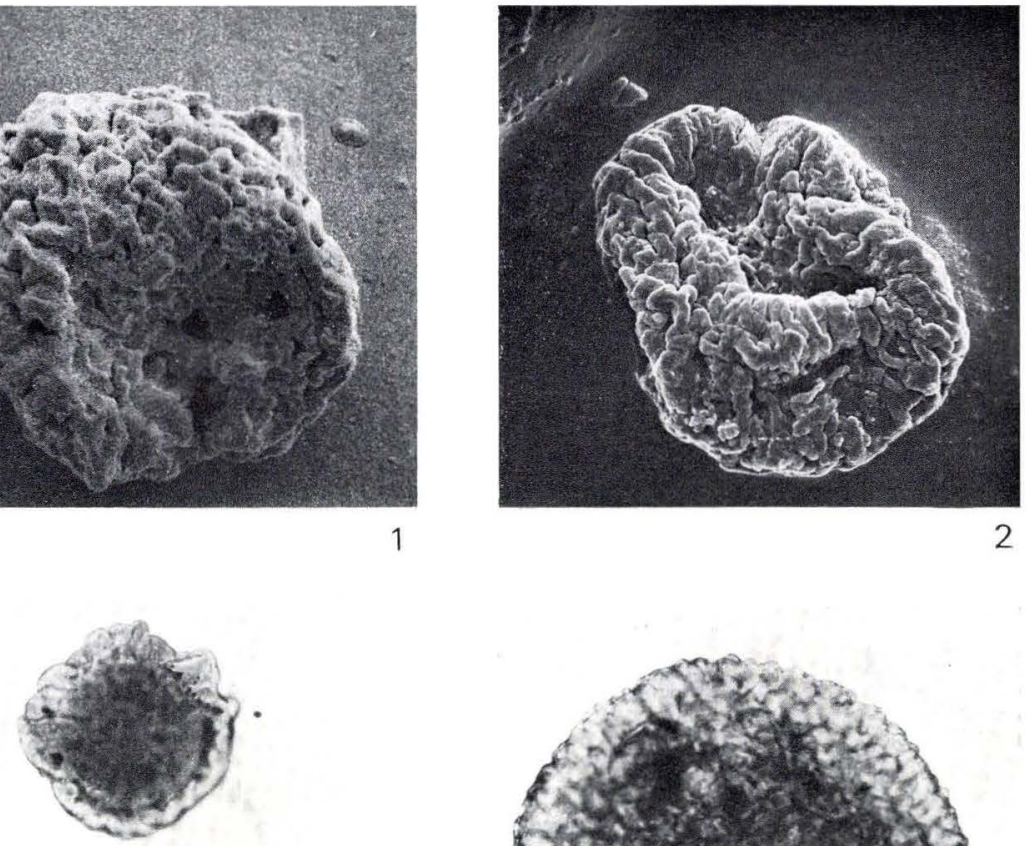

3
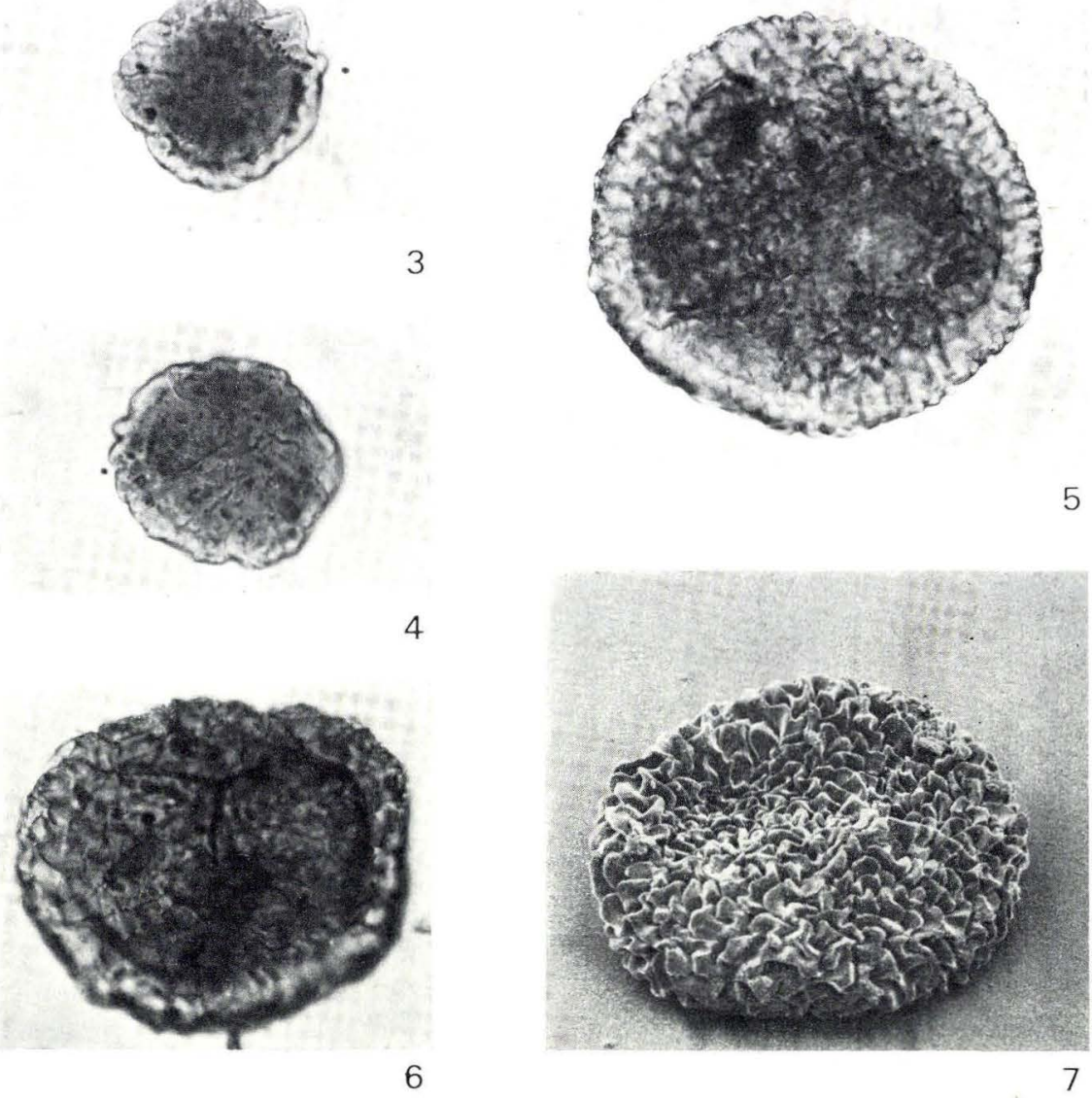


\section{PLATE XIII}

$\times 500$ (figs. $8-9, \times 425$ )

D.G.U. Text Catalogue No. page

Figs. 1-2. Dictyotriletes membranireticulatus n. sp......... 1972-FB-75 47 7739'4-9'", S1 240 SM.

Holotype. Distal view. Fig. 1: high focus, fig. 2: low focus.

Diameter: $55 \mu$, excl. sculpture.

Fig. 3. Dictyotriletes membranireticulatus n. sp.......... 1972-FB-76 $7743^{\prime} 0^{\prime \prime}$, S1 284 SM.

Distal view.

Diameter: $56 \mu$, excl. sculpture.

Fig. 4. Dictyotriletes membranireticulatus n. sp.......... 1972-FB-77 $7743^{\prime} 0^{\prime \prime}, \mathrm{SH}-14-\mathrm{FB}$

Scanning micrograph, proximal view.

Diameter: appr. $60 \mu$, excl. sculpture.

Figs. 5-6. Dictyotriletes cf. submarginatus PLAYFORD

1972-FB-78 $7743^{\prime} 0^{\prime \prime}$, S1 265 SM.

Distal view. Fig. 5: low focus, fig. 6: high focus.

Diameter: $58 \mu$, incl. sculpture.

Fig. 7. Dictyotriletes ef. submarginatus PLAYFORD

1972-FB-79 $7743^{\prime} 0^{\prime \prime}, \mathrm{SH}-14-\mathrm{FB}$.

Scanning micrograph, proximal view.

Diameter: appr. $60 \mu$.

Figs. 8-9. Dictyotriletes cf. submarginatus PLAYFORD

$7743^{\prime} 0^{\prime \prime}, \mathrm{SH}-5-\mathrm{FB}$, No. 4.

Scanning micrographs, $\times 425$.

Fig. 8: equatorial view, fig. 9: distal view.

Diameter: appr. $60 \mu$.

Figs. 8-9: Phot. A. NørGÅrd. 

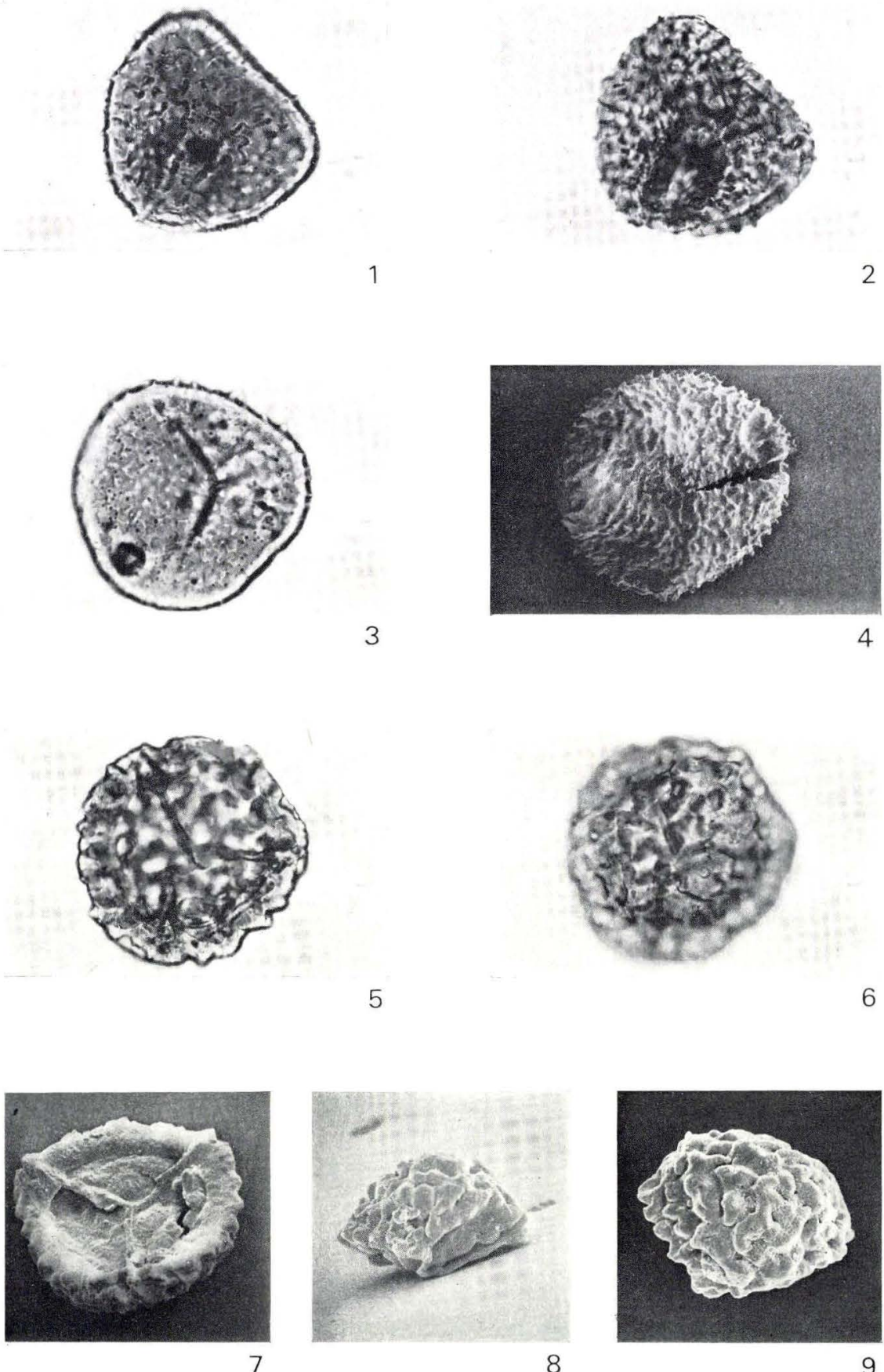

8 


\section{PLATE XIV}

$\times 500$

D.G.U. Text

Catalogue No. page

Fig. 1. Dictyotriletes cheveriensis (PLAYFORD) comb. nov....... 1972-FB-81

7716'0-7", S1 235 SM.

Proximal view.

Diameter: $78 \mu$, excl. sculpture.

Fig. 2. Dictyotriletes cheveriensis (PLAYFORD) comb. nov. .....

1972-FB-82

46 $7743^{\prime} 0^{\prime \prime}, \mathrm{SH}-5-\mathrm{FB}$, No. 11.

Scanning micrograph, distal? view, $\times 500$.

Diameter: appr. $75 \mu$, excl. sculpture.

Fig. 3. Dictyotriletes cheveriensis (PLAYFORD) comb. nov. ......

1972-FB-83

46 $7743^{\prime} 0^{\prime \prime}$, S1 269 SM.

Proximal-equatorial view.

Diameter: $72 \mu$, excl. sculpture.

Fig. 4. Dictytriletes sp. (SI 224 SM).

1972-FB-84

7716'0-7'”, S1 224 SM.

Proximal view.

Diameter: $84 \mu$.

Fig. 5. Convolutispora circumvallata Clayton ..............

$7716^{\prime} 0-7^{\prime \prime}$, S1 247 SM.

Distal view.

Diameter: $78 \mu$, incl. sculpture.

Fig. 6. Convolutispora circumvallata CLAYTON .

1972-FB-86 7739'4-9'", S1 248 SM.

Equatorial view.

Diameter: $90 \mu$, incl. sculpture.

Fig. 2: Phot. A. NørG̊̊RD. 


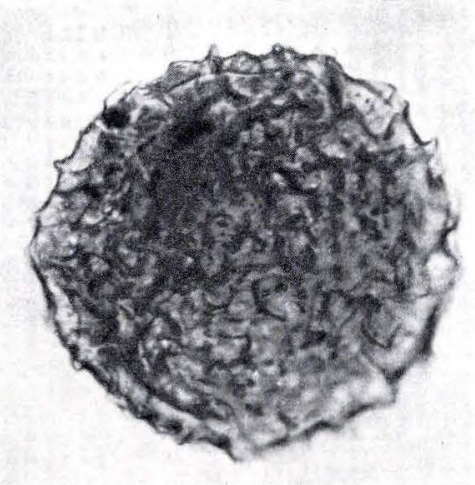

1
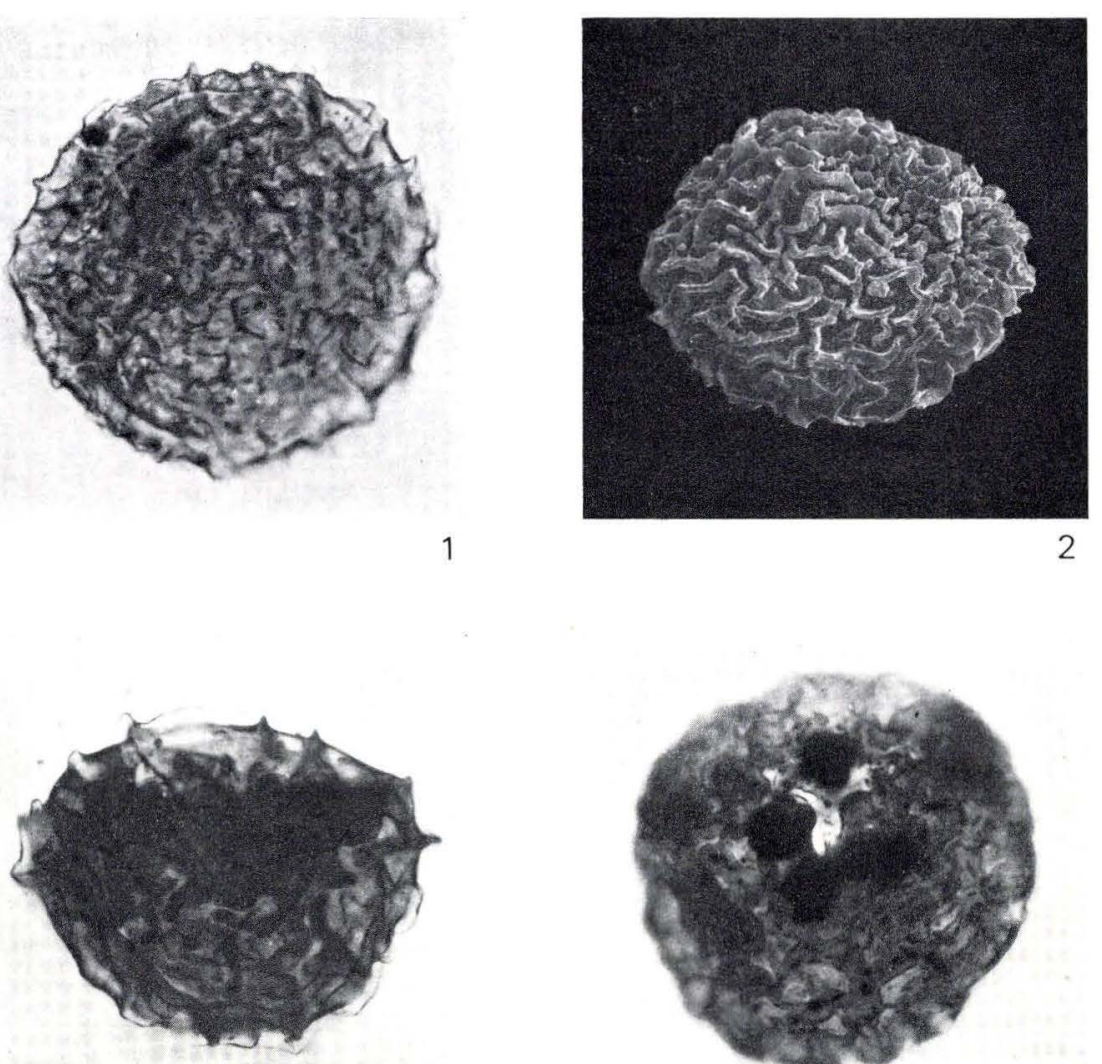

3

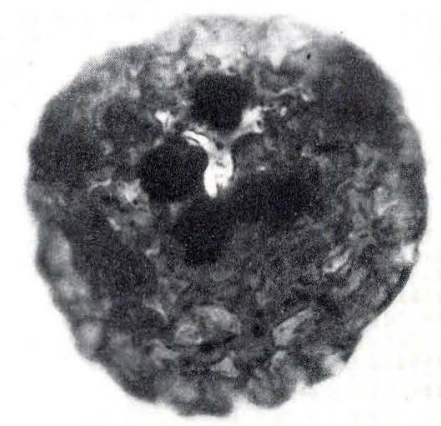

4

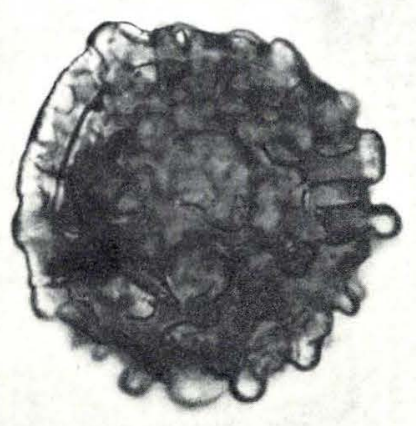

5 
PLATE XV

$\times 500$

D.G.U. Text Catalogue No. page

Fig. 1. Dictyotriletes cancellatus (Waltz) PotoniÉ and KremP.. $7716^{\prime} 0-7^{\prime \prime}$, S1 249 SM.

Proximal view.

Diameter: $111 \mu$, incl. sculpture.

Figs. 2-3. Dictyotriletes sp. (S1 396 SM)

1972-FB-88

49

$7743^{\prime} 0^{\prime \prime}$, S1 396 SM.

Distal view. Fig. 2: high focus, fig. 3: low focus.

Diameter: $51 \mu$, incl. sculpture.

Fig. 4. Perotrilites perinatus HugHes and PLAYFond

1972-FB-89

7716'0-7", K 2.1: 4.8-130.7.

Proximal view.

Diameter: $46 \mu$ (intexine).

Fig. 5. Perotrilites perinatus Hughes and Playford .

1972-FB-90 62 $7743^{\prime} 0^{\prime \prime}$, SI 283 SM.

Proximal view.

Diameter: $65 \mu$ (intexine).

Fig. 6. Perotrilites magnus Hughes and Playford

1972-FB-91

61
Orientation 209 SM.

Diameter: $141 \mu$ (intexine). 

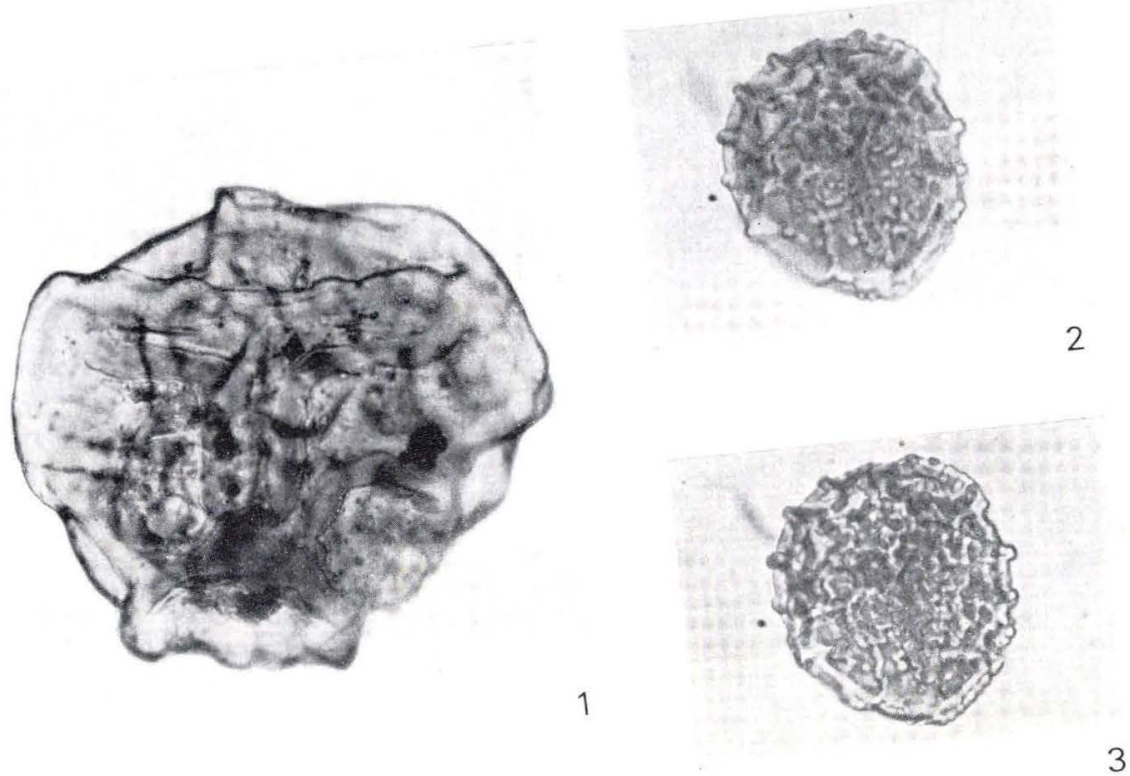

1

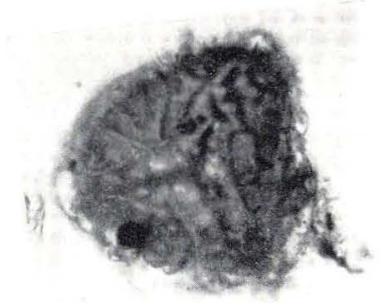

4
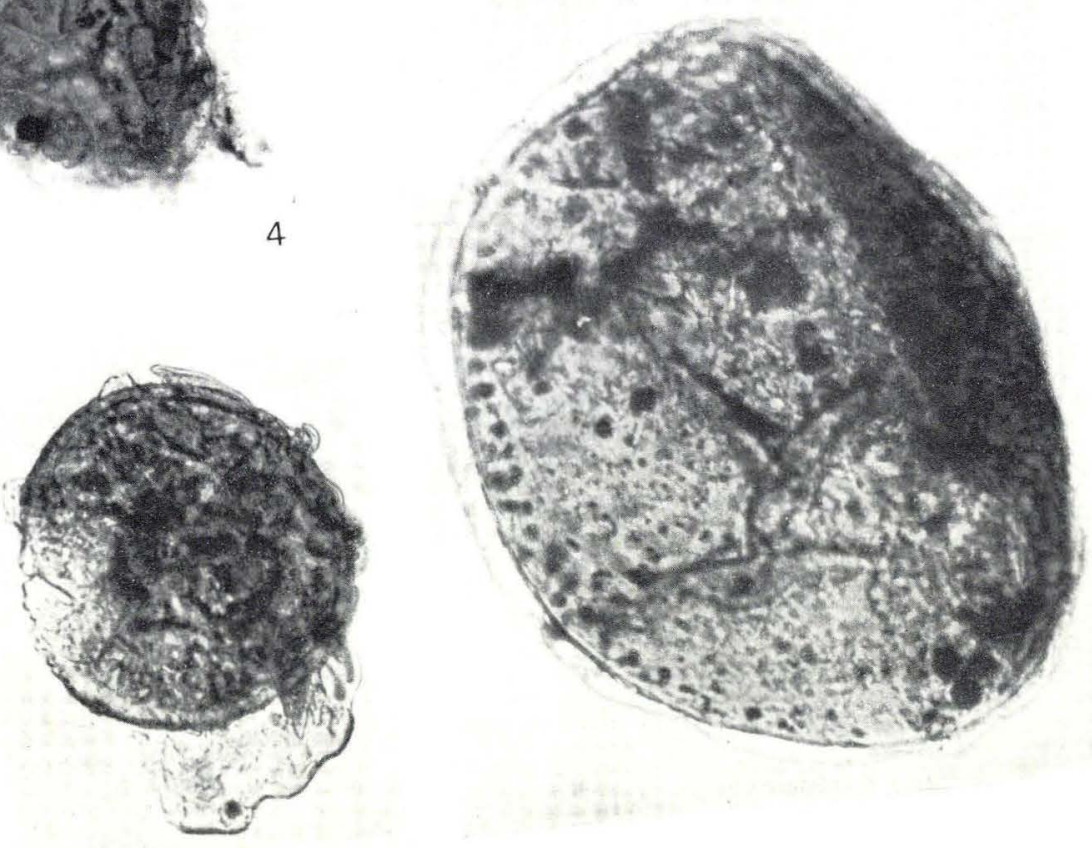
PLATE XVI

$\times 500$ (fig. $6, \times 300$ )

Fig. 1. Murospora sublobata (Waltz) Playford............

D.G.U. Text

Catalogue No. page

1972-FB-92 50

$7743^{\prime} 0^{\prime \prime}$, S1 285 SM.

Proximal view.

Diameter: $42 \mu$.

Fig. 2. Knoxisporites literatus (WAltz) PlAyford........... 1972-FB-93

$7739^{\prime} 4-9^{\prime \prime}$, SI 349 SM.

Distal view.

Diameter: $89 \mu$.

Fig. 3. Rugospora corporata Neves and OWENS var. verrucosa

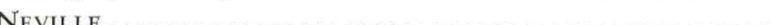

Proximal view.

Diameter: $109 \mu$.

Figs. 4-5. Murospora sp. (S1 298 SM)

1972-FB-95

$7743^{\prime} 0^{\prime \prime}$, S1 298 SM.

Proximal view. Fig. 4: high focus, fig. 5: low focus.

Diameter: $40 \mu$.

Fig. 6. Rugospora corporata NEves and OWENs var. verrucosa Neville . . . . . . . . . . . . . . . . . . . $7743^{\prime} 0^{\prime \prime}$, SH-14-FB.

1972-FB-96

Scanning micrograph, $\times 300$.

Diameter: appr. $120 \mu$.

Fig. 7. Rugospora corporata Neves and OWENS var. verrucosa Neville . . . . . . . . . . . . . . . . . . . . . . . . 7739'4-9', Sl 206 SM.

Proximal view.

Diameter: $122 \mu$. 


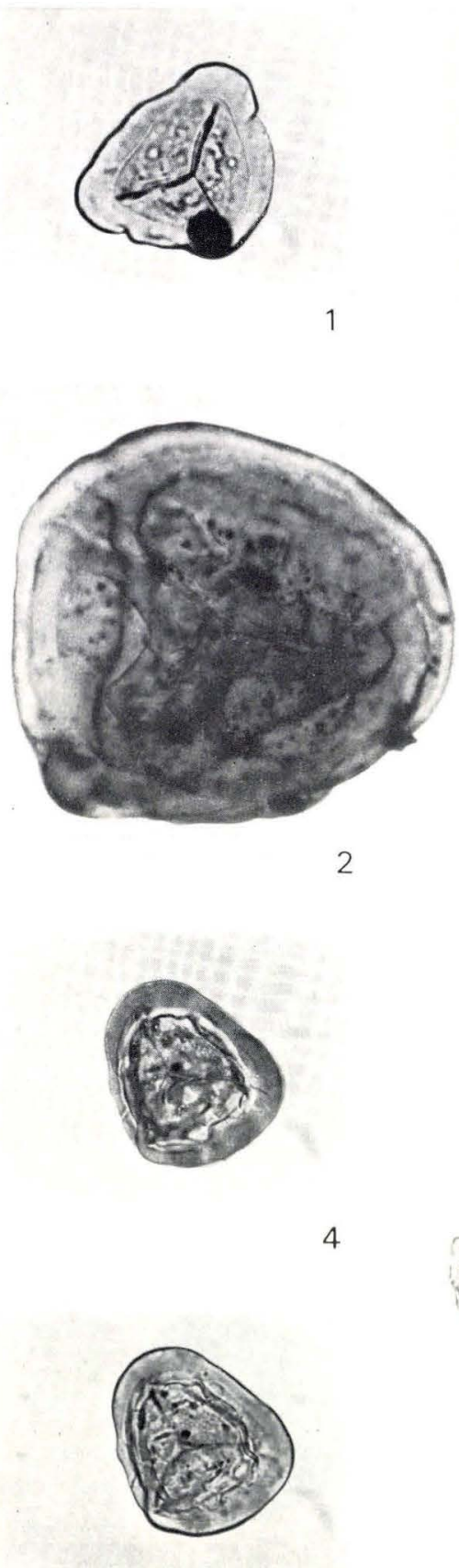

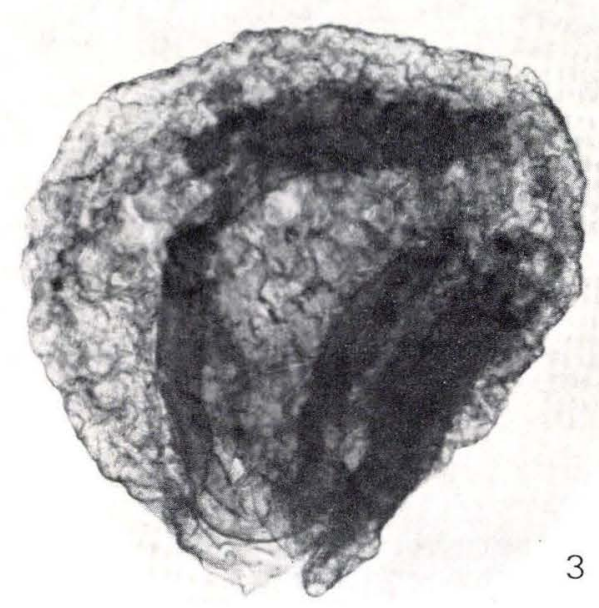
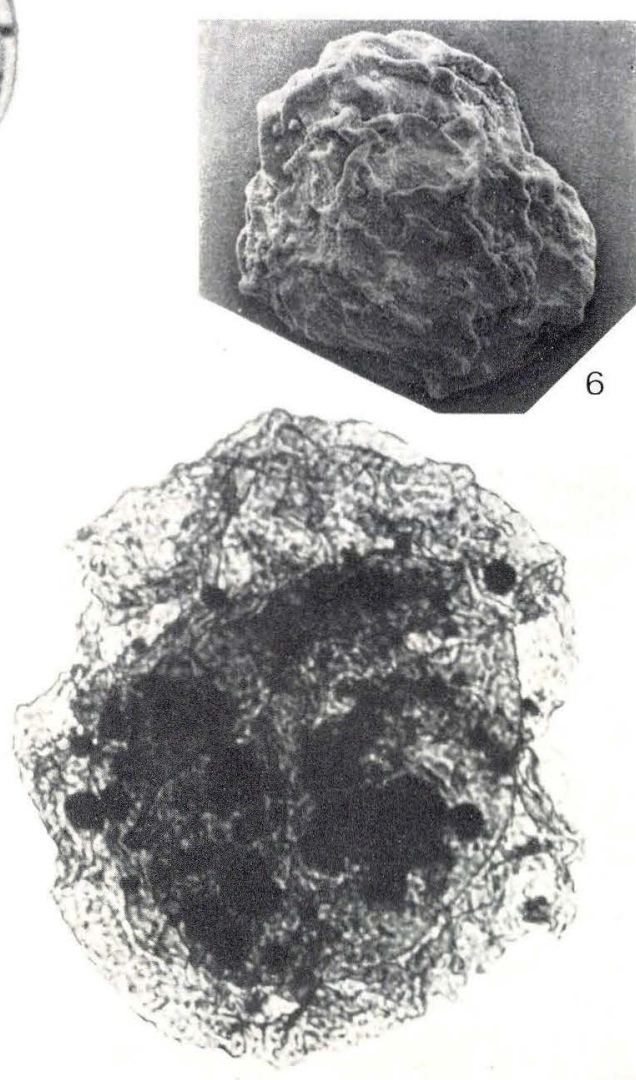
Fig. 1. Stenozonotriletes sp. (S1 306 SM) 1972-FB-98

$7743^{\prime} 0^{\prime \prime}$, S1 306 SM.

Distal view.

Diameter : $45 \mu$.

Fig. 2. Stenozonotriletes sp. (S1 306 SM) 7739'4-9', S1 365 SM.

Distal view.

Diameter : $47 \mu$.

Fig. 3. Stenozonotriletes sp. (S1 303 SM)

7743'0', Sl 303 SM.

Proximal view.

Diameter: $57 \mu$.

Fig. 4. Cyclogranisporites sp. (S1 290 SM).

$7743^{\prime} 0^{\prime \prime}$, S1 394 SM.

Proximal view.

Diameter: $47 \mu$, excl. sculpture.

Figs. 5-6. Stenozonotriletes sp. (S1 275 SM)

7743'0", S1 275 SM.

Distal view. Fig. 5: high focus, fig. 6: low focus.

Diameter: $42 \mu$.

Figs. 7-8. Cyclogranisporites sp. (S1 290 SM). 7743'0", S1 290 SM.

Distal view. Fig. 7: high focus, fig. 8: low focus.

Diameter: $48 \mu$, excl. sculpture. 
Plate XVII
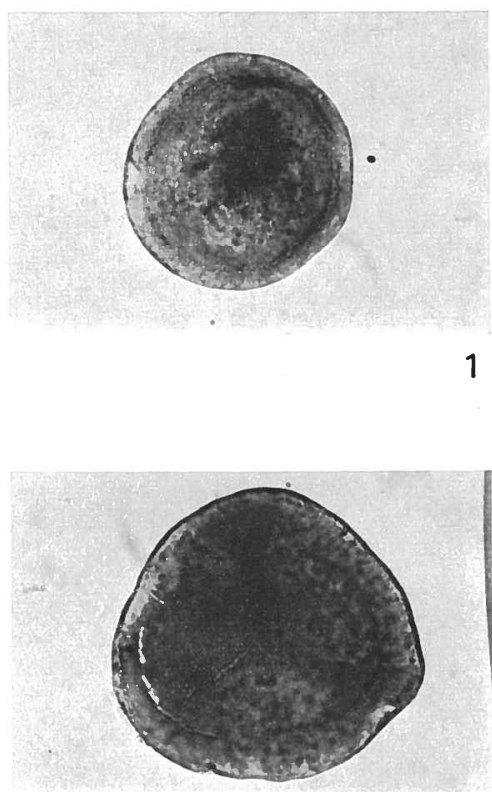

3
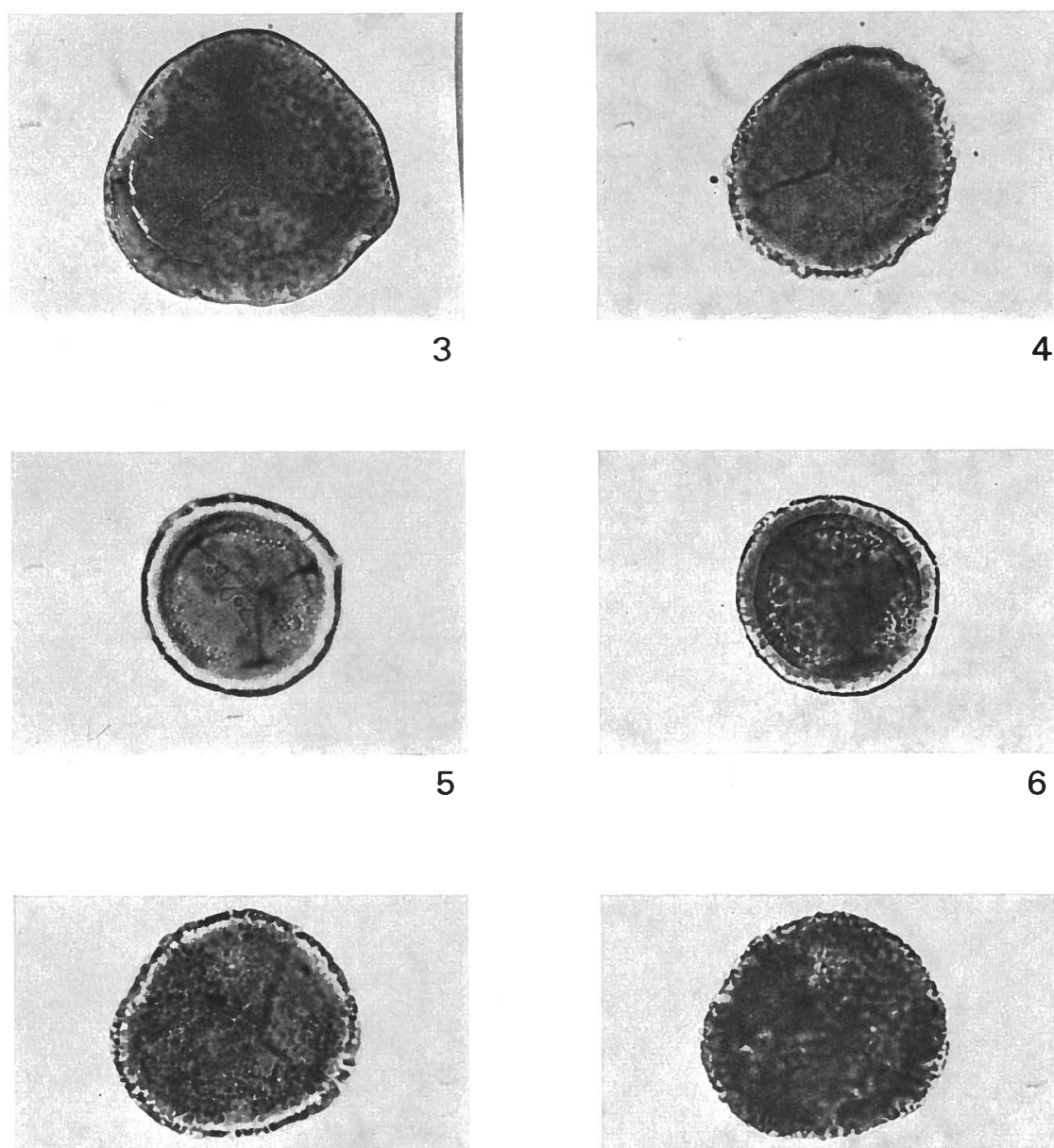

4

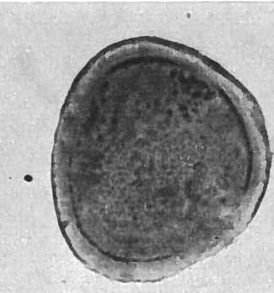

2

6

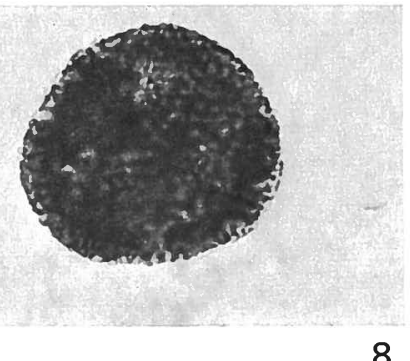

8

8 D.G.U. II. rk. nr. 99 
D.G.U. Text

Catalogue No. page 1972-FB-104

7739'4-9", S1 351 SM.

Distal view.

Diameter: $88 \mu$.

Fig. 2. Knoxisporites sp. (S1 316 SM)

1972-FB-105 52 7739'4-9', S1 316 SM.

Proximal view.

Diameter : $102 \mu$.

Figs. 3-4. Knoxisporites pristinus Sullivan.............. 1972-FB-106 51 7716'0-7"', S1 315 SM.

Proximal view. Fig. 3: high focus, fig. 4: low focus.

Diameter: $74 \mu$.

Figs. 5-6. Knoxisporites pristinus Sullivan............. 1972-FB-107 51

Scanning micrographs, distal view.

Fig. 5: section of distal murus, $\times 2200$.

Diameter: appr. $75 \mu$ (fig. 6).

Figs. 5-6: Phot. A. NøRGÅRD. 
Plate XVIII
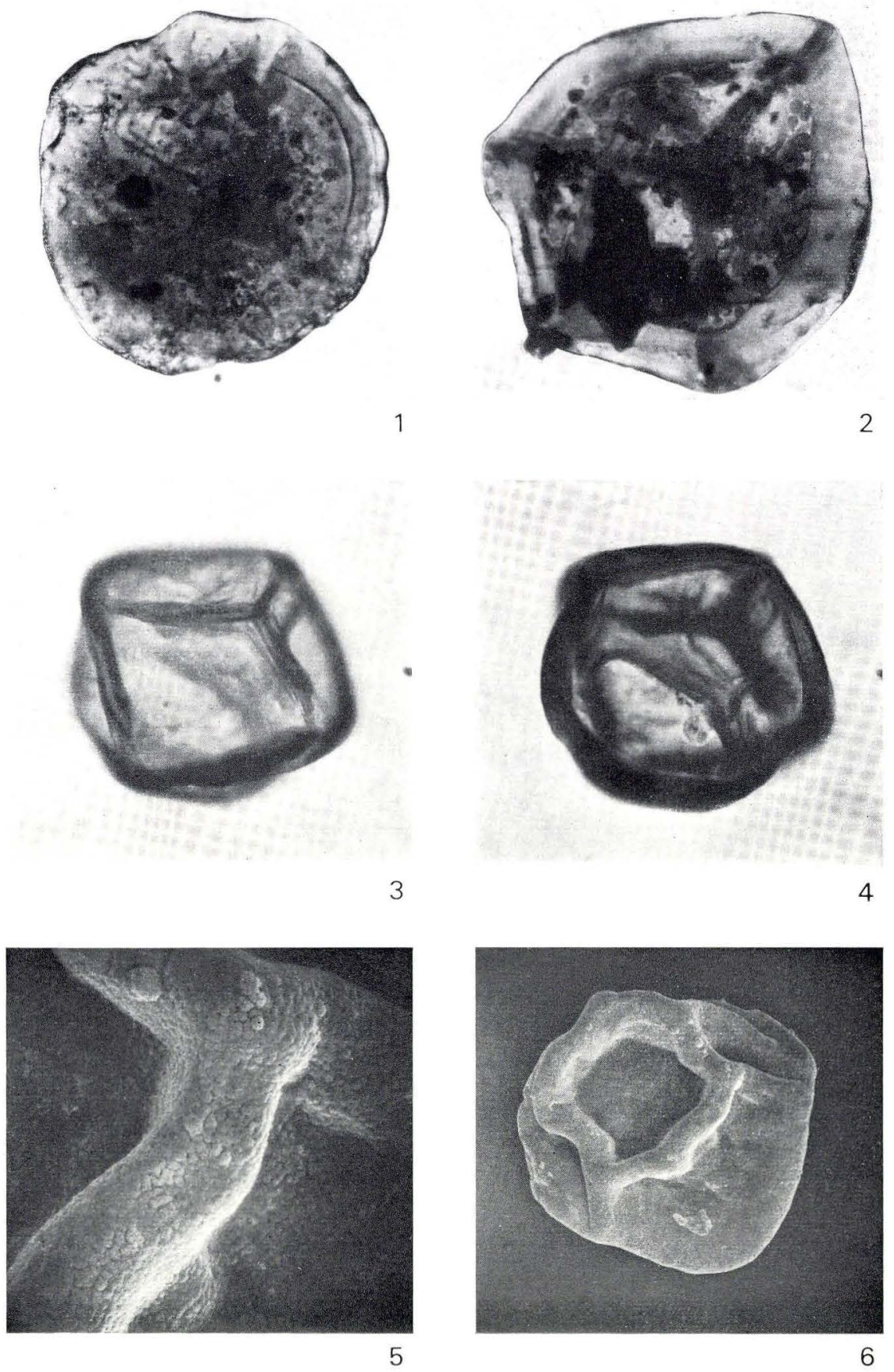

$8 *$ 
Fig. 1. Knoxisporites sp. (SI 342 SM).

$7716^{\prime} 0-7^{\prime \prime}$, Sl 342 SM.

Distal view.

Diameter : $90 \mu$.

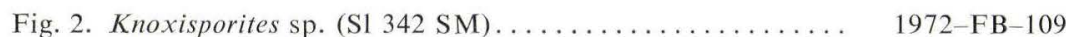
52 7739'4-9'", SI 343 SM.

Proximal-equatorial view.

Diameter: $97 \mu$.

Fig. 3. Anulatisporites? sp. (S1 375 SM)

$1972-\mathrm{FB}-110$ 53 7739'4-9', S1 375 SM.

Distal view.

Diameter : $98 \mu$.

Fig. 4. Tholisporites sp. (S1 345 SM)

1972-FB-111 56 $7743^{\prime} 0^{\prime \prime}$, S1 344 SM.

Distal view.

Diameter: $79 \mu$.

Fig. 5. Tholisporites sp. (S1 345 SM). $7743^{\prime} 0^{\prime \prime}$, S1 345 SM.

Proximal view.

Diameter: $70 \mu$.

Fig. 6. Reticulatisporites copiosus n. sp 7739'4-9', S1 336 SM.

Distal view.

Diameter: $118 \mu$. 


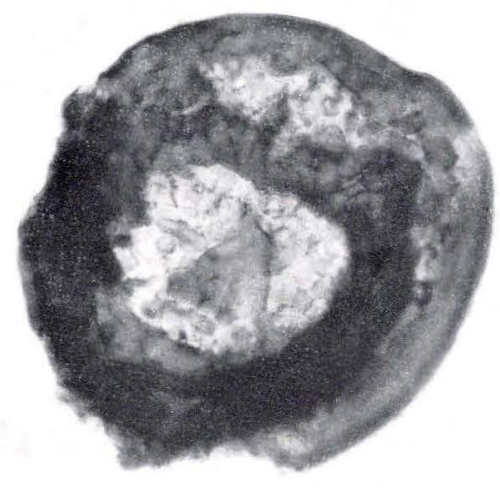

Plate XIX

1
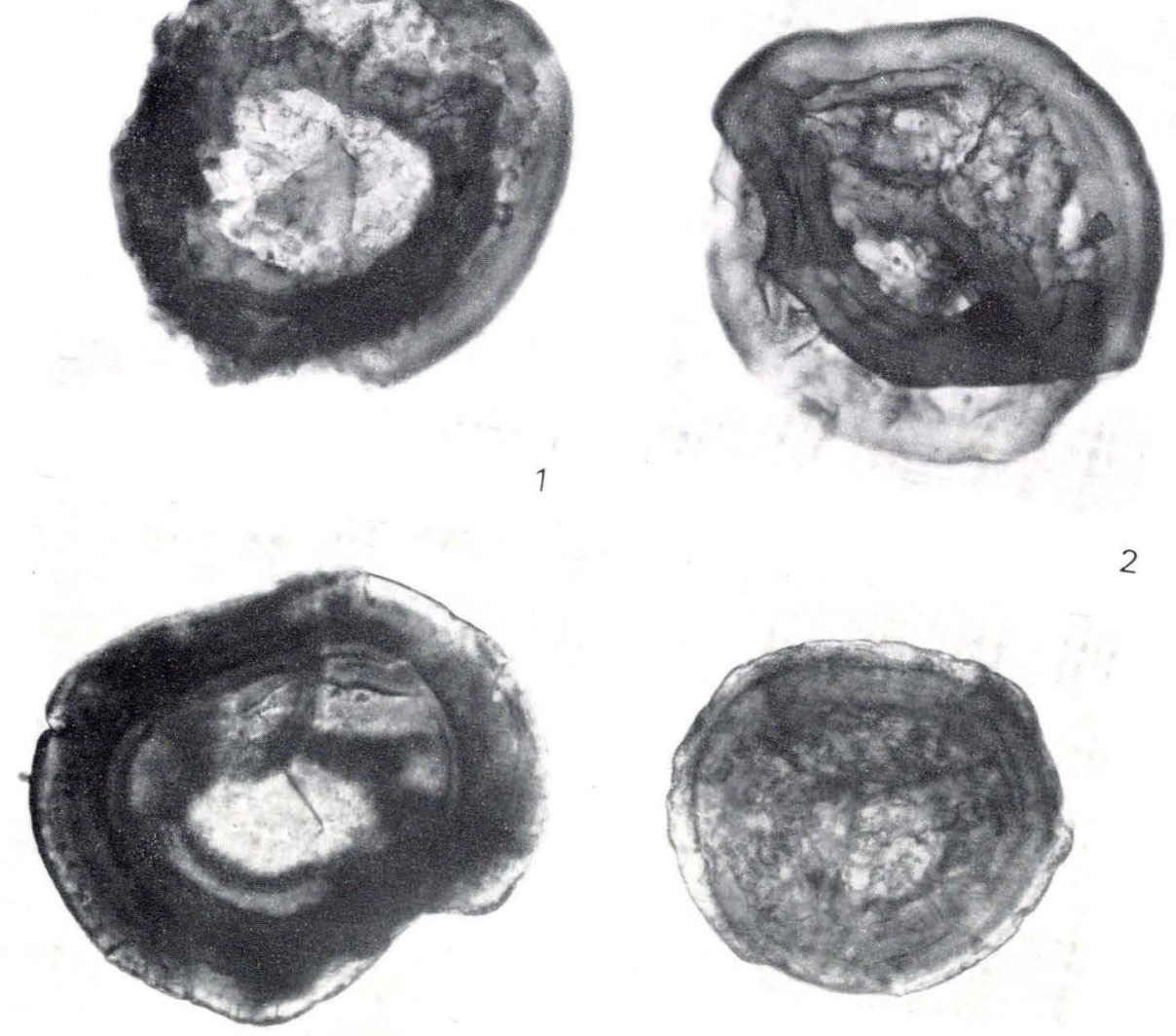

2

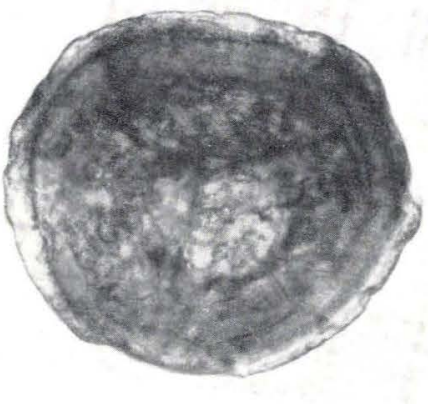

3

4
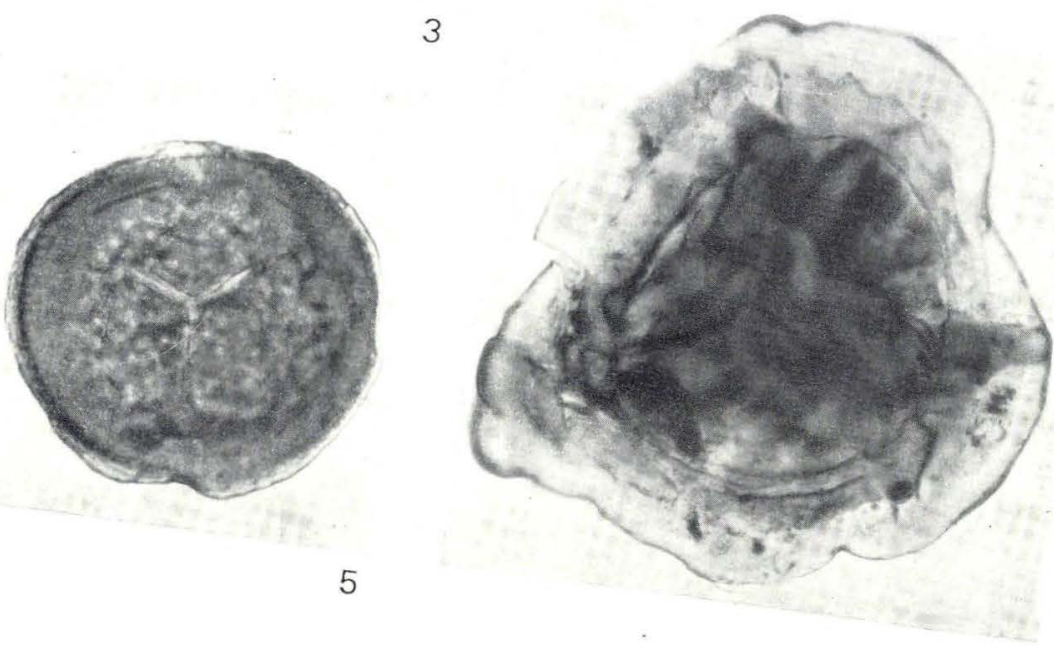
PLATE XX

$\times 500$

D.G.U. Text

Catalogue No. page

Fig. 1. Tholisporites sp. (S1 388 SM).

1972-FB-114 56

$7743^{\prime} 0^{\prime \prime}$, S1 388 SM.

Proximal view.

Diameter: $68 \mu$.

Fig. 2. Reticulatisporites copiosus n. sp.

1972-FB-115

7739'4-9", Sl 334 SM.

Holotype, proximal view.

Diameter: $130 \mu$.

Fig. 3. Reticulatisporites copiosus n. sp.

1972-FB-116

7716'0-7', SH-15-FB, No. 2.

Scanning micrograph, proximal view.

Diameter: appr. $120 \mu$.

Fig. 4. Tholisporites sp. (S1 388 SM).

1972-FB-117 7739'4-9', S1 378 SM.

Distal view.

Diameter: $73 \mu$.

Fig. 5. Reticulatisporites copiosus $\mathrm{n}$. sp............... 1972-FB-118 52 7739'4-9'", S1 337 SM.

Distal view.

Diameter : $149 \mu$. 
Plate XX
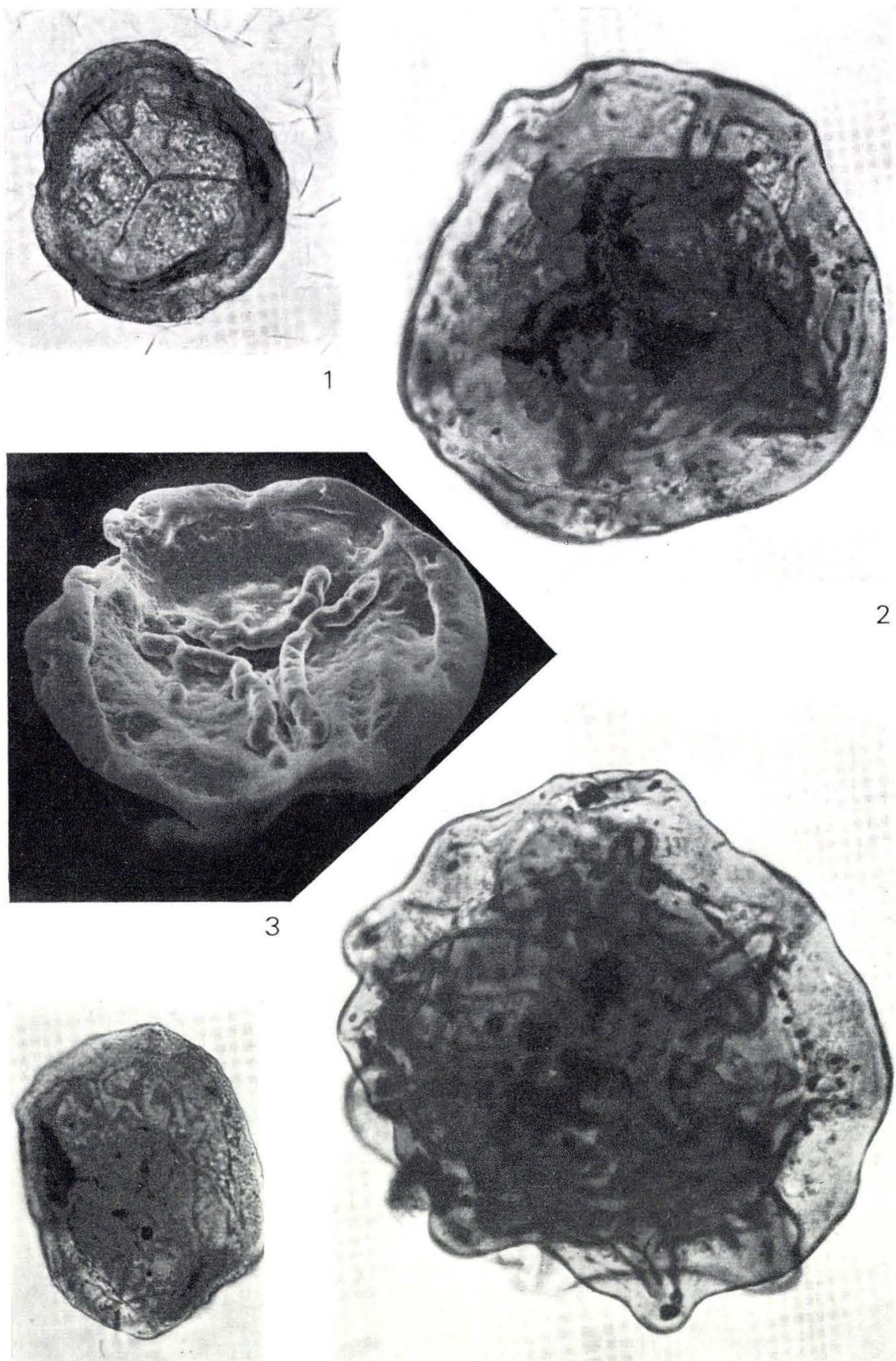
PLATE XXI

$\times 1000$
D.G.U. Text Catalogue No. page 1972-FB-119 54

Fig. 1. Lycospora pusilla (IвRAHIm) Somers. . . . . . . . . . . . $7743^{\prime} 0^{\prime \prime}$, S1 297 SM.

Distal view. Low focus (proximal surface).

Diameter: $31 \mu$.

Fig. 2. Lycospora? rugulosa BUtTerworth and SPINner....... $7270^{\prime}-80^{\prime}$, S1 444 SM.

Distal view. Low focus (proximal surface). Blue filter.

Diameter: $38 \mu$.

Fig. 3. Lycospora pusilla (IвRAHIM) SOMERs. . .

1972-FB-120 54 7743'0", S1 410 SM.

Proximal view.

Diameter: $31 \mu$.

Fig. 4. Tholisporites decorus Bharadwaj and Venkatachala ...

1972-FB-121 7739'4-9", S1 443 SM.

Proximal view.

Diameter: $41 \mu$.

Fig. 5. Lycospora pusilla (IвRAнiм) SOMERs. . . . . . . . . . . . $7743^{\prime} 0^{\prime \prime}$, S1 282 SM.

Proximal view.

Diameter : $27 \mu$.

Fig. 6. Tholisporites decorus Bharadwaj and Venkatachala... $7701^{\prime} 3^{\prime \prime}$, S1 442 SM.

Proximal view.

Diameter : $46 \mu$. 

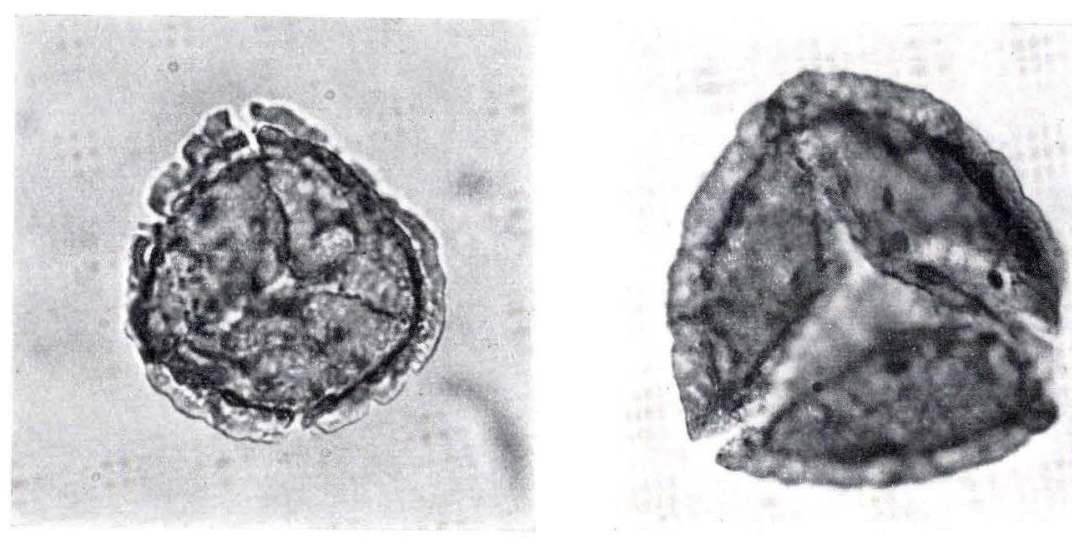

1
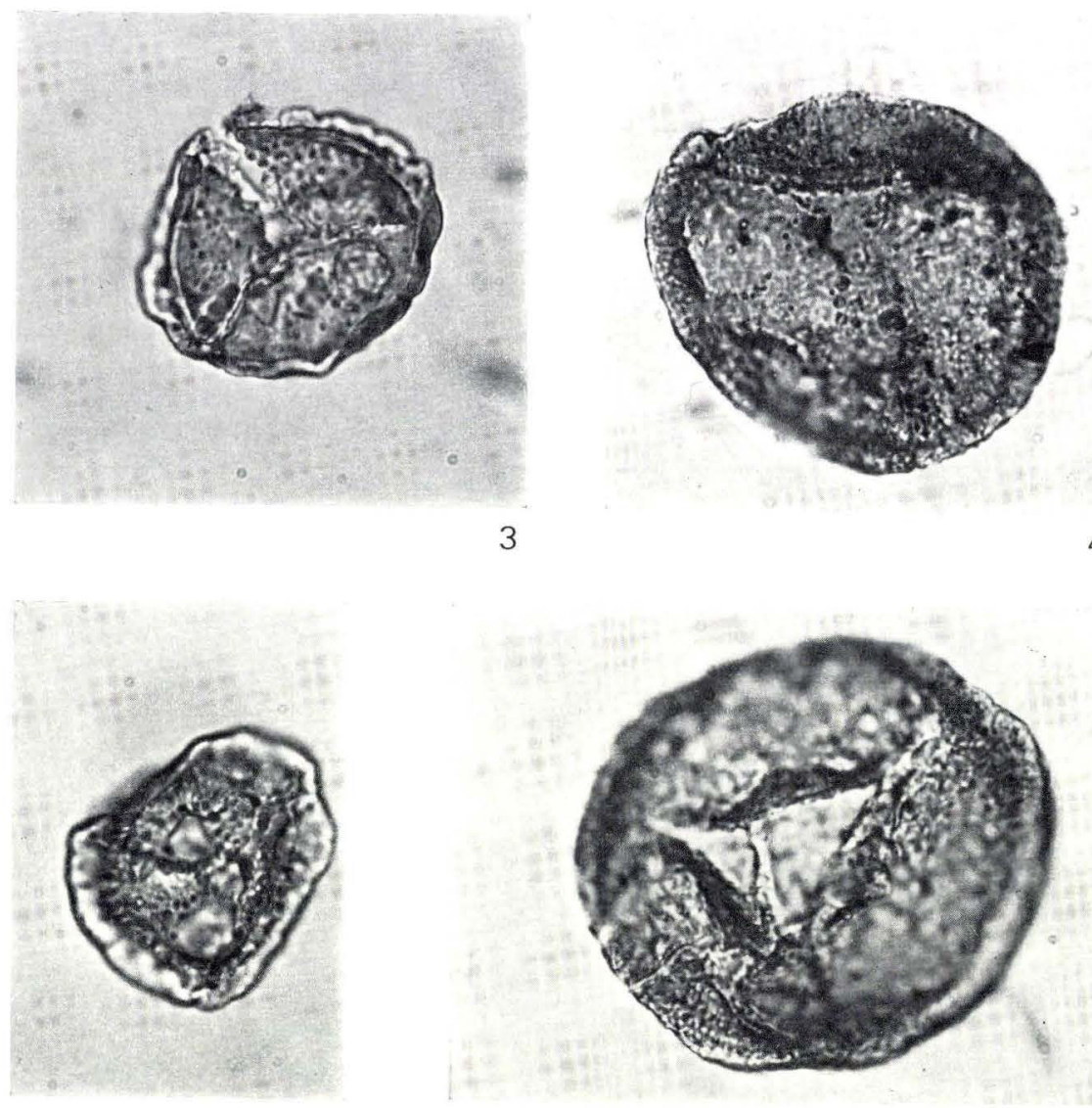
D.G.U. Text Catalogue No. page

Fig. 1. Grandispora echinata HACQUEBARD 1972-FB-124 58 $7743^{\prime} 0^{\prime \prime}$, SI 260 SM.

Distal view.

Diameter: $67 \mu$.

Fig. 2. Grandispora echinata HACQUEBARD

$7743^{\prime} 0^{\prime \prime}, \mathrm{SH}-17-\mathrm{FB}$, No. 3.

Proximal view. Scanning micrograph.

Diameter: $68 \mu$.

Fig. 3. Gen. et sp. indet. (S1 $295 \mathrm{SM}$ )

$7743^{\prime} 0^{\prime \prime}$, S1 295 SM.

Distal view.

Diameter: $62 \mu$.

Fig. 4. Spinozonotriletes sp. (SI 310 SM)

$1972-$ FB-127 $7743^{\prime} 0^{\prime \prime}$, S1 310 SM.

Distal view.

Diameter: appr. $60 \mu$.

Fig. 5. Spelaeotriletes cf. pretiosus (Playford) Neves and Belt $1972-$ FB-128 7701'3", S1 427 SM.

Distal view.

Diameter: $82 \mu$.

Fig. 6. Discernisporites ef. micromanifestus (Hacquebard) Neves

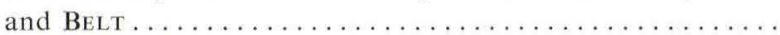
$7743^{\prime} 0^{\prime \prime}$, S1 294 SM.

1972-FB-129 60

Proximal view.

Diameter: $69 \mu$. 
Plate XXII
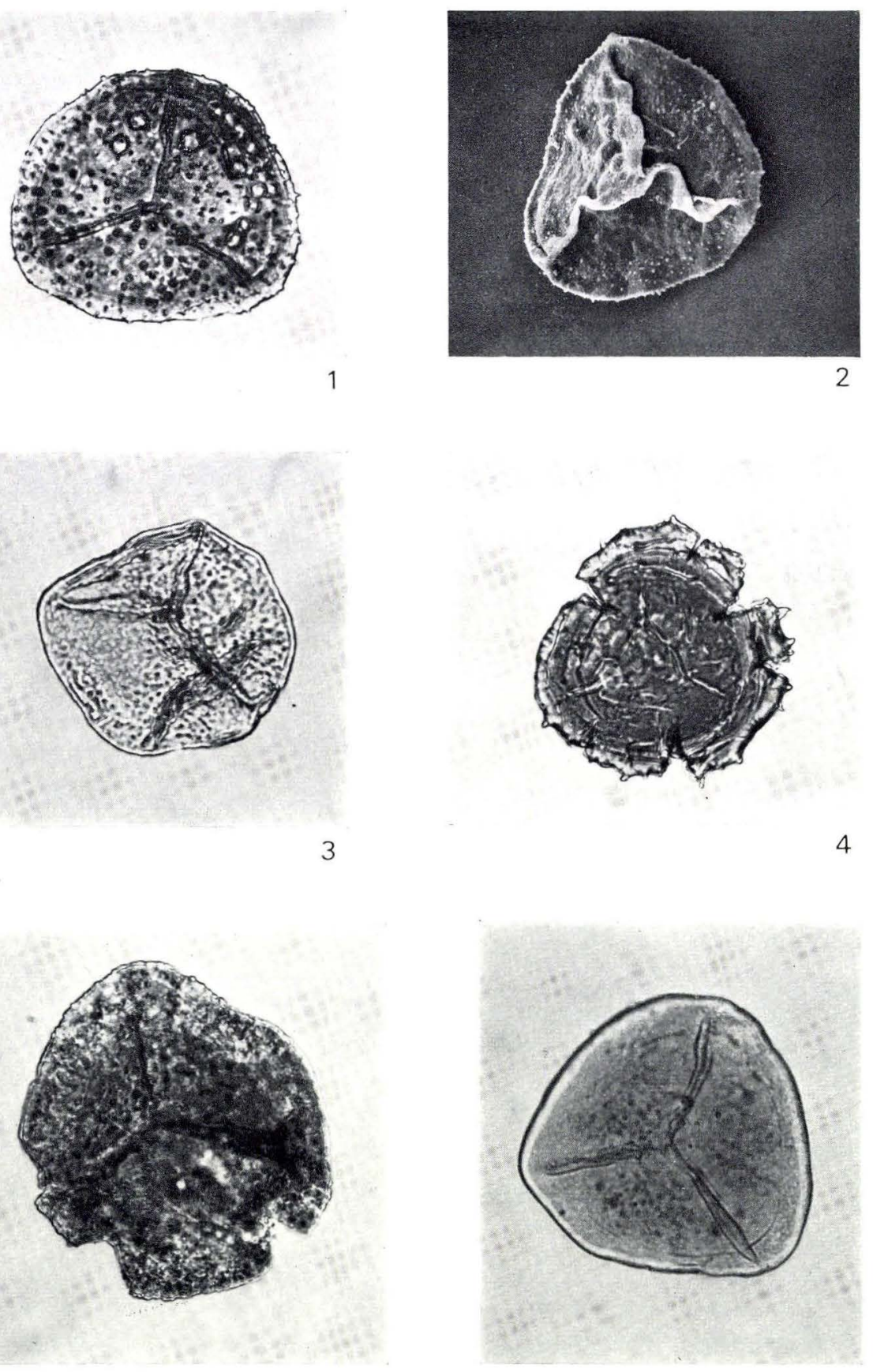


\section{PLATE XXIII}

$\times 500$

D.G.U. Text Catalogue No. page

Figs. 1-2. Aculeispores sp. (S1 261 SM) 1972-FB-130 58

$7743^{\prime} 0^{\prime \prime}$, S1 261 SM.

Proximal view. Fig. 1: high focus, fig. 2: low focus.

Diameter: $60 \mu$.

Figs. 3-4. Aculeispores sp. (S1 259 SM)

1972-FB-131 58

$7743^{\prime} 0^{\prime \prime}$, S1 259 SM.

Distal view. Fig. 3: low focus, fig. 4: high focus.

Diameter: $61 \mu$.

Fig. 5. Auroraspora macra Sullivan

7739'4-9', S1 201 SM.

Distal view.

Diameter: $62 \mu$.

Fig. 6. Auroraspora macra Sullivan ...

$1972-$ FB-133

7739'4-9', S1 203 SM.

Distal view.

Diameter: $70 \mu$.

Fig. 7. Auroraspora cf. solisortus HofFmeister, Staplin and

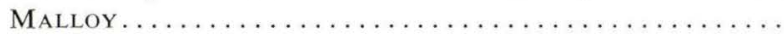
$7743^{\prime} 0^{\prime \prime}$, S1 263 SM.

1972-FB-134

Distal view.

Diameter: $61 \mu$.

Fig. 8. Auroraspora cf. solisortus Hoffmeister, Staplin and

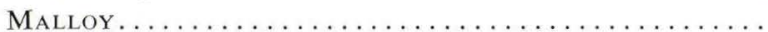
$7743^{\prime} 0^{\prime \prime}$, S1 262 SM.

Proximal view.

Diameter: $62 \mu$. 

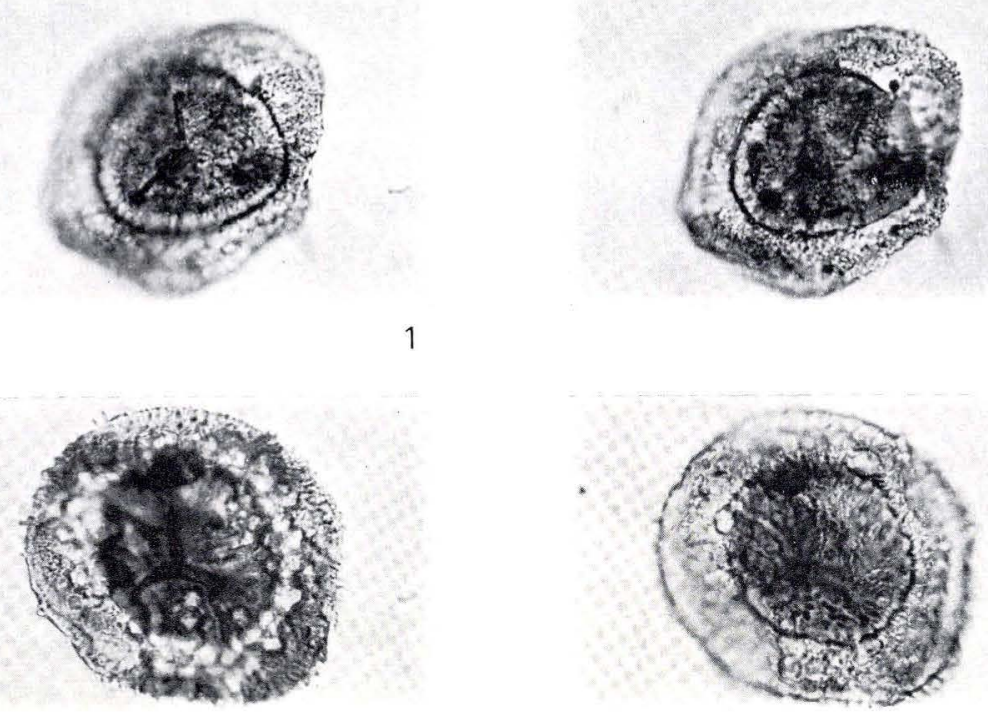

3
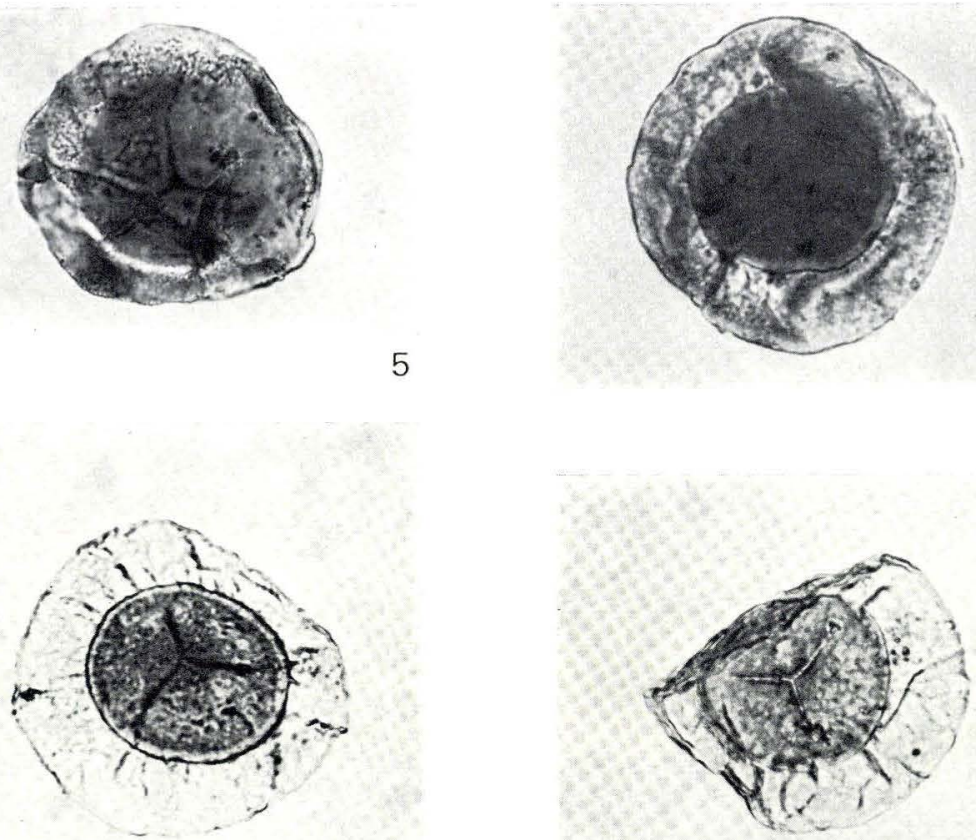
D.G.U. Text Catalogue No. page 1972-FB-136 63

Fig. 1. Tasmanites sp.
7743'0"

Diameter: $69 \mu$.

Fig. 2. Baltisphaeridium sp.

7743'0", Sl 402 SM.

Diameter: $31 \mu$.

Fig. 3. Baltisphaeridium sp.

7743'0', SI 002 PM, 11.8-130.2.

Diameter (body): $28 \mu$.

Figs. 4, 6. Scolecodonts .

$7716^{\prime} 0-7^{\prime \prime}$, SI K 2,6.

Fig. 5. Leiosphaeridia? sp

$1972-$ FB-141

7739'4-9", Sl 362 SM.

Diameter: $96 \mu$.

Fig. 7. Cavatisporites microreticulatus (JACHOWICZ) emend. .....

1972-FB-142 64

Diameter: $112 \mu$. 

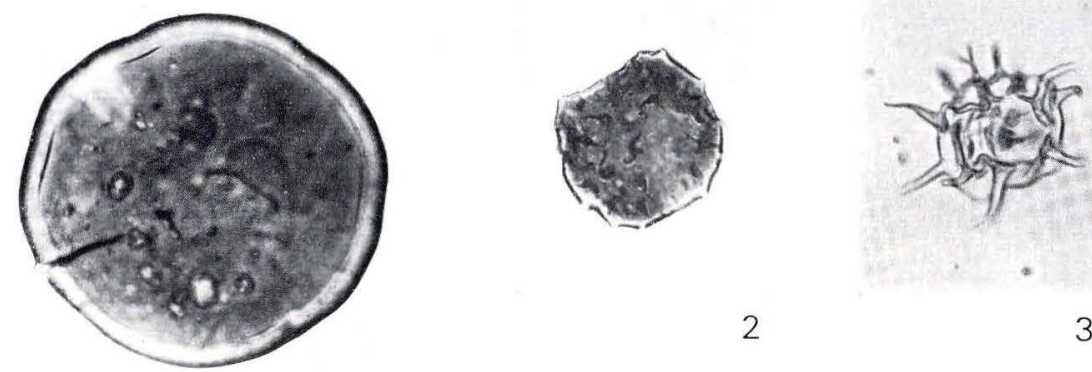

2
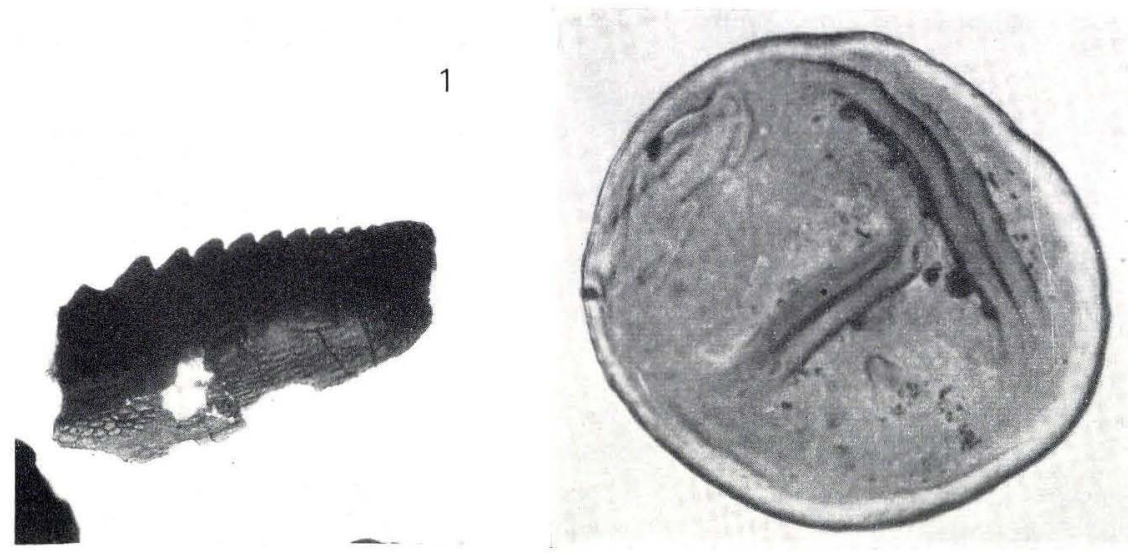

4
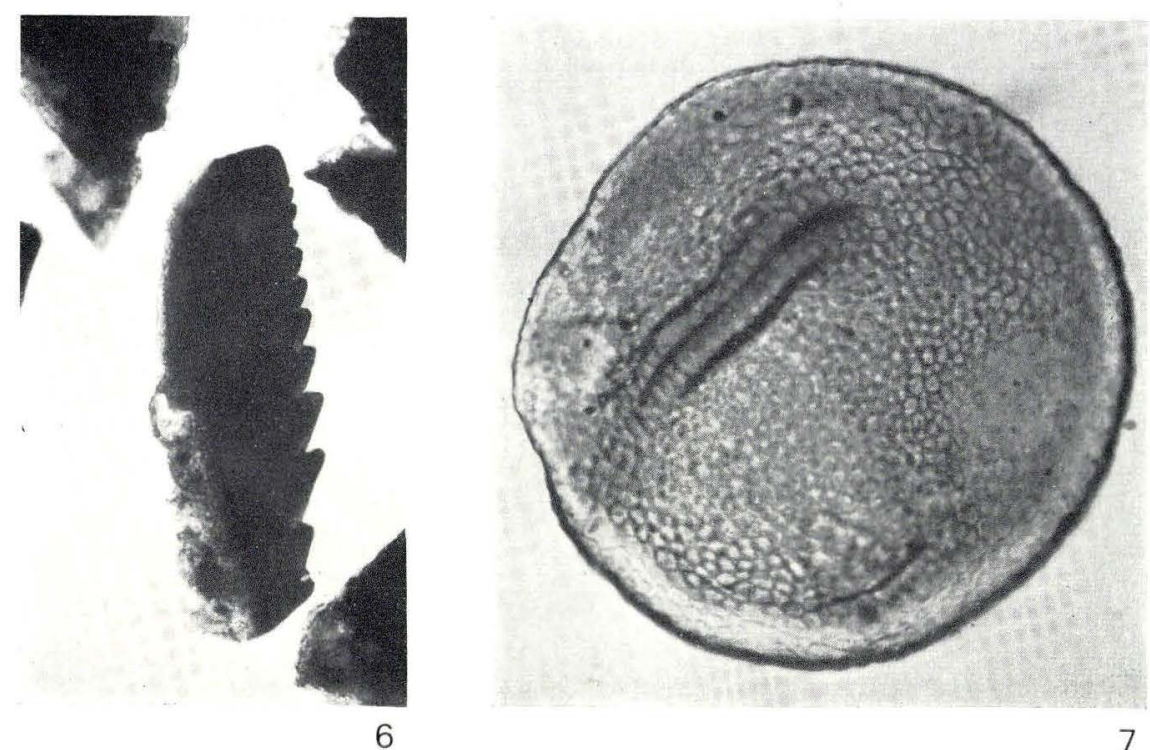

6 